\title{
A família Orchidaceae no município de Morro do Chapéu, Bahia, Brasil
}

\author{
Orchidaceae in Morro do Chapéu, Bahia, Brazil
}

Cláudia Araújo Bastos ${ }^{2,3}$ \& Cássio van den Berg $^{2}$

\begin{abstract}
Resumo
Este trabalho apresenta um estudo florístico das Orchidaceae de Morro do Chapéu, município pertencente à Chapada Diamantina e localizado no estado da Bahia, Brasil. Cinquenta e três espécies distribuídas em 29 gêneros foram reconhecidas no presente trabalho. Dentre os gêneros mais diversos no município destacam-se Epidendrum (cinco espécies), Gomesa (cinco), Encyclia (quatro), e Habenaria (quatro). Morro do Chapéu apresentou 25 espécies exclusivas quando comparado com outros levantamentos regionais da Chapada Diamantina, contribuindo com quatro novos registros para esta área (Galeandra beyrichii, Gomesa barbata, Habenaria josephensis e Prescottia oligantha). Quinze espécies listadas neste levantamento não ocorrem nas outras áreas do leste brasileiro comparadas, estando distribuídas apenas ao longo da Cadeia do Espinhaço. Diferenças no tipo vegetacional, extensão territorial, grau de antropização e amostragem parecem interferir na similaridade florística dessas áreas. São apresentados chave de identificação, descrições, ilustrações e comentários sobre as espécies.

Palavras-chave: Chapada Diamantina, florística, orquídea, taxonomia.
\end{abstract}

\begin{abstract}
This work presents a floristic survey of Orchidaceae in Morro do Chapéu, municipality situated in the Chapada Diamantina, Bahia, Brazil. Fifty three species in twenty nine genera are hereby recognized. Epidendrum (five species), Gomesa (five), Encyclia (four), and Habenaria (four) were registered as the most diverse genera in the region. Morro do Chapéu had twenty five exclusive species compared with other regional surveys in the Chapada Diamantina, contributing with four new records for this area (Galeandra beyrichii, Gomesa barbata, Habenaria josephensis and Prescottia oligantha). Fifteen species listed do not occur in other compared areas of Eastern Brazil, being only distributed over the Cadeia do Espinhaço. Differences among vegetation types, territorial ranges, anthropical degrees and samples, seem to interfere with the floristic similarity of these areas. An identification key, descriptions, commentaries and illustrations of species are provided.
\end{abstract}

Key words: Chapada Diamantina, floristic, orchid, taxonomy.

\section{Introdução}

A família Orchidaceae é uma das maiores dentre as angiospermas com cerca de 24.500 espécies, distribuída por quase todas as regiões do globo com predominância em áreas tropicais e subtropicais (Dressler 1993; 2005). No Brasil ocorrem 2.419 espécies agrupadas em 235 gêneros, destas aproximadamente 1.620 são endêmicas e 419 são registradas para o estado da Bahia (Barros et al. 2010).

AChapada Diamantina faz parte da Cadeia ou Serra do Espinhaço, principal cadeia montanhosa no leste do Brasil (Fig. 1a) que se estende do norte da Bahia ao centro de Minas Gerais (Fig. 1b). O maciço da Chapada Diamantina localizase na extremidade norte da Serra do Espinhaço e se encontra inteiramente na Bahia (Fig. 1b), com uma extensão de $330 \mathrm{~km}$ no sentido de norte a sul. A Chapada Diamantina é uma região de grande diversidade florística e elevado grau de endemismo (Harley 1995, 2005), cujo tipo de vegetação predominante é o campo rupestre (Conceição \& Giulietti 2002; Conceição \& Pirani 2005, 2007; van den Berg \& Azevedo 2005).

\footnotetext{
${ }^{1}$ Dissertação de Mestrado da primeira autora, desenvolvida na Universidade Estadual de Feira de Santana.

${ }^{2}$ Universidade Estadual de Feira de Santana, Dept. Ciências Biológicas, Av. Transnordestina s/n, 44030-900, Feira de Santana, BA.

${ }^{3}$ Autor para correspondência: caubionet@yahoo.com.br
} 


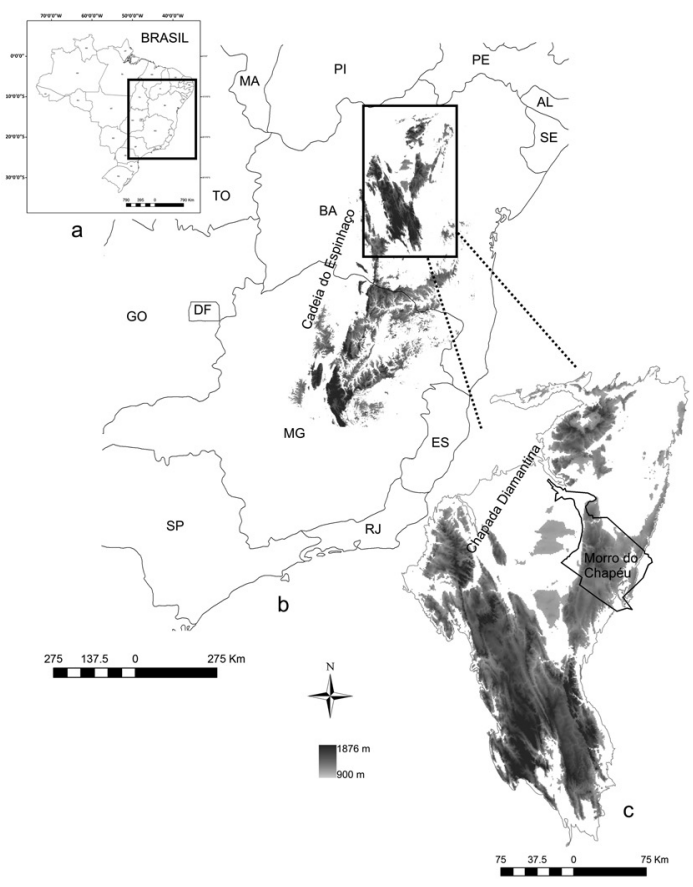

Figura 1 - Mapa de localização da área de estudo: a. Leste do Brasil; b. Cadeia do Espinhaço; c. Morro do Chapéu na Chapada Diamantina.

Figure 1 - Location map of study area: a. Eastern Brazil; b. Cadeia do Espinhaço c. Morro do Chapéu in the Chapada Diamantina.

Muitos estudos vêm sendo desenvolvidos na Chapada Diamantina desde a década de 1980, a Flórula de Mucugê (Harley \& Simmos 1986), a Flora do Pico das Almas (Stannard 1995), a lista das Espécies Vasculares do Morro do Pai Inácio, Palmeiras e Serra da Chapadinha, Lençóis (Guedes \& Orge 1998), a Lista das Plantas Vaculares de Catolés (Zappi et al. 2003) e o levantamento da família Orchidaceae no Parque Municipal de Mucugê (Azevedo \& van den Berg 2007a). Van den Berg \& Azevedo (2005) listaram 161 espécies de Orchidaceae para a Chapada Diamantina, baseados nos levantamentos publicados e nos materiais de herbários. Embora Toscano de Brito \& Cribb (2005) tenham recentemente publicado um inventário das Orchidaceae da Chapada Diamantina, com 175 espécies listadas para a família, o município de Morro do Chapéu foi apenas parcialmente amostrado. O presente trabalho teve como objetivo preencher essa lacuna, apresentando um tratamento para as espécies do município. São fornecidas descrições, ilustrações e chaves de identificação, além de dados sobre a distribuição geográfica, hábito e período de floração das espécies de Morro do Chapéu.

\section{Material e Métodos}

O município de Morro do Chapéu localizase ao Norte da Chapada Diamantina, (Fig. 1c), a aproximadamente $398 \mathrm{~km}$ de Salvador, entre as coordenadas $10^{\circ} 46^{\prime}-12^{\circ} 0^{\prime} \mathrm{S}$ e $41^{\circ} 30^{\prime}-40^{\circ} 42^{\prime} \mathrm{W}$, a altitudes que variam entre 480 e $1.293 \mathrm{~m}$ e ocupando uma área de $5.920 \mathrm{~km}^{2}$ (Rocha \& Costa 1995). Faz parte da região semi-árida do estado da Bahia e sua posição geográfica confere-lhe características climáticas do tipo tropical, fortemente alteradas pela altitude. Isso proporciona clima privilegiado e singularidade a esse município dentro do chamado "Polígono das Secas" (Barbosa 1995; Lobão 2006). Quatro tipos climáticos são identificados no município de Morro do Chapéu, os quais são fortemente influenciados pelo relevo de formas tabulares (Barbosa 1995). Na área central do município, com altitude superior a $1.000 \mathrm{~m}$, predomina o clima tropical de altitude, com verão brando, com temperatura média do mês mais frio (julho) inferior a $18^{\circ} \mathrm{C}$ e temperatura média do mês mais quente (janeiro) inferior a $22^{\circ} \mathrm{C}$. Nas áreas com altitude entre 800 e $1.000 \mathrm{~m}$, o clima é também do tipo tropical de altitude, com verão quente, sendo este predominante no município. Com altitude inferior a $800 \mathrm{~m}$, os índices pluviométricos são determinantes para os dois últimos tipos climáticos que seguem: o tipo tropical subúmido, com índices pluviométricos anuais entre 800 e $1.200 \mathrm{~mm}$, com ocorrência sazonal de máxima pluviosidade de novembro a março (verão). É encontrado a leste do município, onde, em decorrência da orientação do relevo, mais do que da altitude, ocorrem as chamadas "chuvas orográficas". Nessa região climática pode ser encontrada a cobertura vegetal do tipo florestal, predominando a floresta estacional decidual ou semidecidual. O clima semi-árido e quente conta com pluviosidade inferior a $800 \mathrm{~mm}$ e cobertura vegetal de caatinga. É encontrado no vale do Rio Salitre, ao norte, a oeste, nos limites com os municípios: João Dourado, São Gabriel e América Dourada, no vale do Rio Jacaré; e ao sul, na direção da localidade de Duas Barras do Morro (Barbosa 1995).

Diferentes subformações vegetais podem revestir um mesmo tipo de solo em Morro do Chapéu, o que parece ser explicado pela variação espacial, temporal e de intensidade do regime 
pluviométrico, embora a compartimentação do relevo promova a existência de mesoclimas, por vezes bastante diferenciados das áreas vizinhas. Outro fator relevante são as baixas temperaturas registradas à noite, propiciando a precipitação na forma de orvalho, fator esse aproveitado pelas plantas na época da estiagem. São observadas cinco regiões fitoecológicas principais no município: cerrado, caatinga, floresta estacional sempre-verde, floresta estacional decidual e vegetação rupestre. A vegetação é em parte complexa, diante das faixas de transição entre os ambiente aí presentes, e a flora rica em espécies ornamentais, dentre as quais se destacam as orquídeas, ocorrendo também plantas alimentícias, medicinais e de interesse madeireiro (Silva 1995). A diversidade florística da área já há muito desperta o interesse de pesquisadores e muitas expedições foram realizadas no município desde a década de 1960, com destaque para importantes coletores como R. M. Harley e G. Hatschbach. Semelhante a este levantamento para a família Orchidaceae, foi realizado em Morro do Chapéu, o inventário florístico do gênero Evolvus L. (Convolvulaceae) (Junqueira \& SimãoBianchini 2006).

O trabalho de campo foi realizado entre maio de 2007 e novembro de 2008, especialmente durante o período de floração das espécies (outubro a fevereiro). Realizaram-se 11 excursões, com duração de pelo menos três dias cada, percorrendo-se de forma aleatória o máximo de extensão do município, sendo que em cada viagem foi feita uma programação de coleta para que pontos acessíveis e com poucos registros de Orchidaceae na área de estudo fossem visitados. Todo material coletado foi depositado no herbário HUEFS. A identificação das espécies foi feita com base em bibliografias especializadas como Cogniaux (1893-1896, 1898-1902, 1904-1906), Hoehne (1942), Pabst \& Dungs (1975, 1977), Barbosa Rodrigues (1996) e Toscano de Brito $\&$ Cribb (2005), bem como através de consultas a especialistas. As descrições das espécies basearam-se nos materiais coletados, assim como em espécimes das coleções dos herbários: ALCB, CEPEC, ESA, HB, HRB, HUEFS, MBM, RB, SP e SPF (acrônimos segundo Holmgren et al. 1990). As terminologias botânicas empregadas foram baseadas em Harris \& Harris (1994) e Stearn (2004). O termo Keiki é utilizado nas descrições e se refere aos rebentos que surgem no lugar das flores em uma inflorescência (Toscano de Brito
\& Cribb 2005), sendo muito comum no gênero Epidendrum L. A medida do comprimento total da planta inclui também a inflorescência. Os períodos de floração aqui fornecidos baseiamse em informações contidas nas etiquetas de herbário dos espécimes examinados, assim como em observações de campo. Uma lista completa das exsicatas examinadas pode ser encontrada no final do manuscrito. Para espécies com apenas um material examinado, foram estudados materiais adicionais, preferencialmente de áreas da Chapada Diamantina, disponíveis no acervo do HUEFS. Os nomes dos autores dos táxons estão abreviados de acordo com Brummitt \& Powell (1992). A definição taxonômica dos gêneros segue as circunscrições de Govaerts et al. (2006) e Pridgeon et al. (1999, 2001, 2003, 2006). Dados de distribuição geográfica, domínios fitogeográficos e endemismo das espécies foram extraídos de Barros et al. (2010) e adicionalmente de Angely (1965), Azevedo \& van den Berg (2007a, b), Barbero (2007), Barros \& Pinheiro (2004), Barros (1987, 1994), Batista \& Bianchetti (2003), Batista et al. (2008), Borba et al. (2000, 2002), Buzatto \& Machado (2011), Buzatto et al. (2007, 2010), Castro Neto \& Campacci (2006), Conceição \& Giulietti (2002), Conceição \& Pirani (2005, 2007), Conceição et al. (2007), Cruz et al. (2003), Cunha \& Forzza (2007), Dittrich et al. (1999), Ferreira \& Pansarin (2010), Freitas et al. (2011), Harley \& Mayo (1980), Harley \& Simmon (1986), Koehler \& Amaral (2004), Menini Neto et al. (2004, 2007), Meyer \& Franceschinelli (2010), Monteiro (2007), Pabst \& Dungs (1975, 1977), Pabst (1972a, 1972b), Pansarin \& Pansarin (2008), Pedroso de Moraes et al. (2010), Peron (1989), Ribeiro et al. (2005), Rocha \& Waechter (2006), Romero-González et al. (2008), Schuster et al. (2010), Smidt (2003), Toscano de Brito \& Cribb (2005), Toscano de Brito \& Queiroz (2003), Toscano de Brito $(1995,1998)$, van den Berg \& Azevedo (2005) e através de consulta aos vários herbários. Foram ilustradas prioritariamente as espécies que não constam em Toscano de Brito $\&$ Cribb (2005).

\section{Resultados e Discussão}

Foram encontradas 53 espécies de Orchidaceae no município de Morro do Chapéu, distribuídas em 29 gêneros. Os mais diversos foram Epidendrum e Gomesa R.Br., com cinco espécies cada, seguidos 
por Encyclia Hook. e Habenaria Willd., com quatro espécies, Bulbophyllum Thouars, Cattleya Lindl., Cyrtopodium R.Br. e Prescottia Lindl., com três espécies, e Campylocentrum Benth. e Anathallis Barb.Rodr., ambos com duas espécies. Os demais 19 gêneros foram representados por uma única espécie.

A maioria das espécies presentes no município ocorre exclusivamente em áreas de floresta (49\%). Áreas de caatinga e campo rupestre têm aproximadamente a mesma riqueza de espécies, $19 \%$ e 17\%, respectivamente. Embora a caatinga seja o tipo de vegetação predominante no município, esse elevado número de espécies florestais é justificado pelo fato de ambientes úmidos serem comumente os mais ricos em Orchidaceae (Pabst \& Dungs 1975; Dressler1993). Cerca de $9 \%$ das espécies ocorrem em mais de um ambiente na área estudada, provavelmente pela existência de regiões de transição entre os tipos vegetacionais aí presentes, que chegam a formar diferentes tipos fitofisionômicos difíceis de serem distinguidos (Silva 1995), somando-se a isso o fato de algumas espécies colonizarem com facilidade os mais diferentes ambientes, como é o caso do Epidendrum secundum Jacq. que foi encontrado nos trê tipos vegetacionais do município. Quanto ao hábito das espécies, cerca de $40 \%$ são exclusivamente epífitas, $30 \%$ são exclusivamente terrestres e $19 \%$, exclusivamente rupícolas, com aproximadamente $7 \%$ apresentando mais de um hábito.

Das 53 espécies encontradas neste trabalho, 43 foram listadas para a Chapada Diamantina por Toscano de Brito \& Cribb (2005), mas apenas 14 destas foram citadas como ocorrentes no município de Morro do Chapéu (Acianthera ochreata (Lindl.) Pridgeon \& M.W.Chase (como Pleurothallis ochreata Lindl.), Bifrenaria tyrianthina Rchb.f., Bulbophyllum exaltatum Lindl., Bulbophyllum manarae Foldats, Catasetum hookeri Lindl., Cattleya elongata Barb.Rodr., Cyrtopodium flavum Link \& Otto ex Rchb.f. (como Cyrtopodium polyphyllum (Vell.) Pabst ex F.Barros), Encyclia alboxanthina Fowlie, Encyclia kundergraberii V.P.Castro \& Campacci, Epidendrum warasii Pabst, Epistephium lucidum Cogn. (como Epistephium sclerophyllum Lindl.), Gomesa gravesiana (Rolfe) M.W.Chase \& N.H.Williams (como Oncidium gravesianum Rolfe), Prosthechea moojenii (Pabst) W.E.Higgins e Sobralia sessilis Lindl. Esse dado é bastante significativo e mostra como a soma de objetivos, metodologia e esforço de amostragem podem influenciar os resultados e gerar uma impressão errada em relação a riqueza de uma área.

São novos registros para a Chapada Diamantina: Galeandra beyrichii Rchb.f., Gomesa barbata (Lindl.) M.W.Chase \& N.H.Williams, Habenaria josephensis Barb.Rodr. e Prescottia oligantha (Sw.) Lindl. Apesar da Polystachya estrellensis Rchb.f. não ter sido citada em nenhum dos levantamentos realizados na Chapada Diamantina, é de se supor que essa espécie ocorra em outras localidades dessa região, sendo citada como Polystachya concreta (Jacq.) Garay $\&$ H.R. Sweet, comumente confundida com $P$. estrellensis (Pansarin \& Amaral 2006). Capanemia therezae Barb.Rodr., uma espécie do Sul e Sudeste brasileiros, citada, até então, no nordeste, apenas para Pernambuco (Harley \& Mayo 1980; Barros et al. 2010; Buzatto et al. 2010), foi encontrada entre os materiais de Morro do Chapéu depositados no HUEFS sob o número de Andrade-Lima (6136) que o coletou em 1970. Esse material manteve-se identificado como um espécie de Bulbophyllum Thouars até 2008, quando a primeira autora o identificou como C. therezae. A informação de primeira ocorrência para a Bahia foi registrada em Bastos (2009), embora Buzzato \& Machado (2011) a considerassem inédita, estando baseados no mesmo material.

Comparando-se a lista das Orchidaceae de Morro do Chapéu com outros levantamentos regionais realizados na Chapada Diamantina (Tab. 1), constata-se a existência de 25 espécies exclusivas desse município, o que sugere uma grande diversidade florística na área. São espécies de ampla distribuição na Chapada Diamantina, citadas em todos os levantamentos: Acianthera ochreata, Cattleya elongata, Epidendrum secundum, Epistephium lucidum e Gomesa blanchetii (Rchb.f.) M.W.Chase \& N.H.Williams. As três primeiras e G. blanchetii são rupícolas, ocorrendo em afloramentos rochosos comumente encontrados nas áreas comparadas. Bulbophyllum exaltatum, que também é rupícola, e Prescottia leptostachya Lindl., são também amplamente distribuídas na Chapada não sendo citadas apenas para o Morro do Pai Inácio. Dentre as áreas comparadas, Catolés (Toscano de Brito \& Queiroz 2003) e Mucugê (Harley \& Simmons 1986; Azevedo \& van den Berg 2007a) compartilham o maior número de espécies com Morro do Chapéu (19 e 20 espécies, respectivamente), o que parece estar relacionado ao 


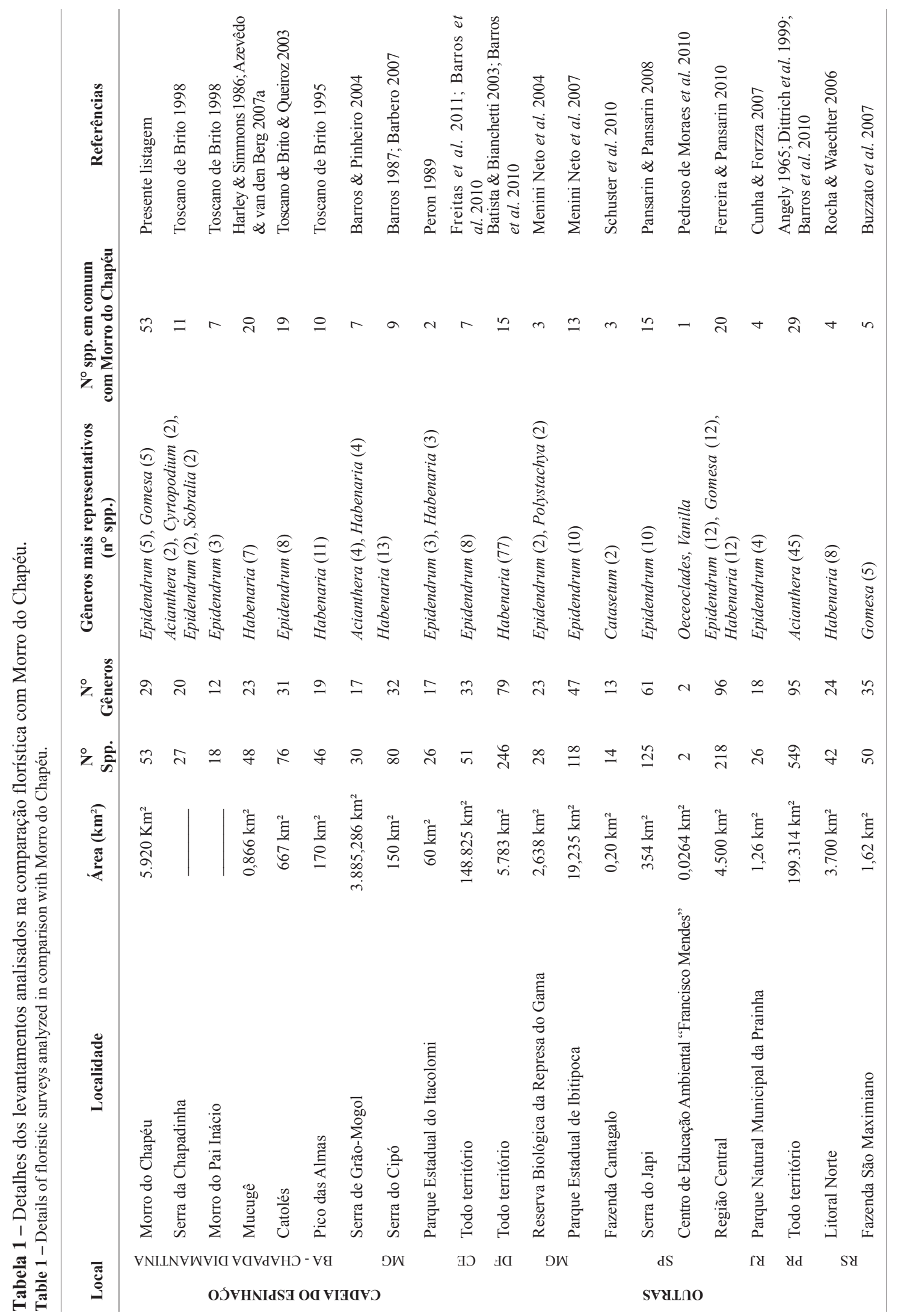


grande número de espécies levantadas nessas áreas. A presença de fisionomias similares entre Morro do Chapéu e Mucugê parece justificar a ocorrência de 20 espécies em comum, além do fato de a maioria das Orchidaceae encontradas nessas duas áreas crescer nas florestas e nos campos rupestres. Com a localidade denominada Chapadinha (Toscano de Brito 1998), no município de Lençóis, Morro do Chapéu apresenta 11 espécies em comum; sendo dez com o Pico das Almas (Toscano de Brito 1995), e com o Morro do Pai Inácio (Toscano de Brito 1998), apenas sete espécies.

Das novas ocorrências para a Chapada Diamantina, todas, exceto $P$. oligantha, ou seja, mais 35 espécies, ainda não haviam sido citadas para o restante da Cadeia do Espinhaço (Barros 1987; Peron 1989; Barros \& Pinheiro 2004; Azevedo \& van den Ber 2007b; Meyer \& Franceschinelli 2010), sendo que Habenaria parviflora Lindl. é citada na cadeia do Espinhaço apenas por Meyer \& Franceschinelli (2010) que realizaram o levantamento das plantas vasculares associado às áreas úmidas na região. Essa espécie de Habenaria, que ocorre no município de Morro do Chapéu, é listada para a Chapada Diamantina por van den Berg \& Azevedo (2005), mas sem localidade definida. Em relação à porção mineira da Cadeia do Espinhaço, Morro do Chapéu compartilha o maior número de espécies com a Serra do Cipó (Barros 1987), nove espécies, seguida por Grão Mogol (Barros \& Pinheiro 2004), sete espécies, e apenas duas espécies com o Parque Estadual de Itacolomi (Peron 1989). Essa baixa similaridade pode está associada ao esforço amostral que parece ter sido maior em Morro do Chapéu, cujo levantamento restringiu-se exclusivamente a Orchidaceae. Além disso, o período limitado de floração e frutificação de plantas da Cadeia do Espinhaço, observado entre outras, em Orchidaceae, pode influenciar nos resultados de levantamentos florísticos se as coletas não forem feitas de modo extensivo (Rapini et al. 2002; Azevedo \& van den Berg 2007b). No entanto, é consenso entre pesquisadores da área que a porção mineira do Espinhaço apresenta uma riqueza significativa, a qual merece especial atenção para a conservação da biodiversidade (Echternacht et al. 2011). As espécies com ampla distribuição na Chapada Diamantina ocorrem, de modo geral, também nas demais áreas da Cadeia do Espinhaço consideradas na comparação, sendo que o Epidendrum secundum só não é citado para o Parque Estadual do Itacolomi e nas áreas úmidas da Cadeia. Essa espécie é a mais amplamente distribuída ao longo do Espinhaço, o que é justificado pela sua ampla distribuição na América tropical (Dunsterville \& Garay 1961; Pabst \& Dungs 1975; Barbosa Rodrigues 1996).

Comparando o levantamento aqui apresentado com outras áreas do leste brasileiro (Tab. 1) constata-se que 15 espécies ocorrentes em Morro do Chapéu não ocorrem naquelas áreas, estando distribuídas apenas ao longo da Chapada Diamantina ou demais áreas da Cadeia do Espinhaço, sendo cerca da metade delas tipicamente de afloramentos rochosos. Isso porque a Cadeia do Espinhaço tem topografia, clima e altitude que influenciam fortemente sua composição florística, apresentando, como tipo vegetacional predominante, os campos rupestres, nos quais há um número significativo de espécies raras ou com distribuição restrita (Harley \& Simmons 1986; Giulietti \& Pirani 1988; Harley 1988, 1995; Conceição et al. 2005; Ribeiro et al. 2005). Morro do Chapéu compartilha com o levantamento do Ceará (Barros et al. 2010; Freitas et al. 2011) sete espécies; com o Distrito Federal (Batista \& Bianchetti 2003; Barros et al. 2010) 15; com áreas de Minas Gerais que não fazem parte da Cadeia do Espinhaço, 14 espécies no total, sendo três com a Reserva Biológica da Represa do Grama (Menini Neto et al. 2004) e 13 com o Parque Estadual de Ibitipoca (Menini Neto et al. 2007); com o Parque Natural Municipal da Prainha no Rio de Janeiro (Cunha \& Forzza 2007) são quatro espécies; com os levantamentos realizados em áreas diferentes em São Paulo somam-se 25 espécies, sendo três com a Fazenda Cantagalo (Schuster et al. 2010), 15 com a Serra do Japi (Pansarin \& Pansarin 2008), uma com o Centro de Educação Ambiental "Francisco Mendes" (Pedroso de Moraes et al. 2010) e 20 com a região central de São Paulo (Ferreira \& Pansarin 2010). Com o estado do Paraná (Angely 1965; Barros et al. 2010) foram 29 espécies em comum e com o Rio Grande do Sul foram apenas quatro espécies em comum no litoral norte (Rocha \& Waechter 2006) e cinco na Fazenda São Maximiano (Buzatto et al. 2007).

Apesar de não fazer parte da Cadeia do Espinhaço, o Parque Estadual de Ibitipoca em Minas Gerais, que pertence ao Complexo da Mantiqueira, compartilha com Morro do Chapéu quase o mesmo número de espécies (13) que toda a porção mineira da Cadeia do Espinhaço (14). Isso está ligado ao fato de o campo rupestre ser a 
formação mais extensa no Parque, (Menini Neto et al. 2007) e as espécies compartilhadas pelas áreas em comparação serem comumente encontradas nesse tipo vegetacional, sobretudo em campos rupestres de quartzito. A baixa similaride com a Reserva Biológica da Represa do Grama também em Minas Gerais, está relacionada, por sua vez, ao fato dessa área ser constituída por florestas estacionais semideciduais montana e submontana, fragmentadas pela atuação antrópica. Esse tipo de vegetação cobre apenas pequena extensão no município de Morro do Chapéu e das três espécies compartilhadas com a Represa do Grama, uma (Epidendrum secundum) ocorre aí sempre como rupícola nos floramentos do Ribeirão do Grama (Menini Neto et al. 2004).

O levantamento de Orchidaceae da Serra do Japi, da região central do estado de São Paulo e do estado do Paraná inteiro são maiores que a lista de Morro do Chapéu, embora este município possua uma área territorial bem maior. Os mencionados levantamentos foram realizados em áreas predominantemente de floresta e se considerarmos que mais da metade das espécies de orquídeas brasileiras ocorrem em áreas de floresta (Barros et al. 2010) é compreensível que todos os levantamentos que incluam esse tipo vegetacional apresentem elevada riqueza quando comparados com áreas como Morro do Chapéu, cuja cobertura vegetal é constituída por caatinga em grande parte da sua extensão. Quando são comparados levantamentos florísticos realizados no Brasil, áreas ecotonais entre a Mata Atlântica e o Cerrado, como a região central de São Paulo, tendem a ser mais diversas que regiões de Cerrado somente, perdendo só para regiões exclusivamente de Mata Atlântica (Ferreira \& Pansarin 2010). Em geral, os ambientes úmidos, próximos ao mar e com relevo montanhoso costumam ser as áreas mais ricas em espécies de Orchidaceae (Pabst \& Dungs 1975; Dressler 1993). A diversidade de Orchidaceae de Morro do Chapéu é também menor que a do Distrito Federal. O município tem uma área aproximadamente do mesmo tamanho do território do DF, no entanto, o número de espécies do DF é quase o quíntuplo do levantamento aqui apresentado. Isso se deve, em parte, ao maior esforço de coleta e amostragem no Distrito Federal (Batista \& Bianchetti 2003), mas outro detalhe é que o DF é um centro de riqueza de alguns gêneros de cerrado, a exemplo de Habenaria, que sozinho apresenta 77 espécies no inventário de
Batista \& Bianchetti (2003). Em contrapartida, o estado do Ceará inteiro, com uma área 25 vezes maior que Morro do Chapéu, apresenta riqueza de orquídeas bem menor, o que sugere a deficiência amostral nesse tipo de levantamento abrangente, que busca listar várias famílias de plantas em uma área extensa, ainda mais que o principal trabalho analisado para o Ceará (Freitas et al. 2011) listou apenas as espécies depositadas em um único herbário do próprio estado, ignorando as possibilidades amostrais de herbários do sudeste com coleção significativa de vários estados brasileiros.

Além do já mencionado esforço amostral no levatamento florístico, a intervenção antrópica nas áreas estudadas parece ser mais um fator responsável pelo baixo número de espécies encontradas. No entando é importante considerar a dimensão das áreas na comparação e o foco do estudo. Assim, o fato de Morro do Chapéu, que também possui muitas áreas antropizadas, apresentar um número de espécies bem maior que o Centro de Educação Ambiental "Francisco Mendes", por exemplo, deve-se, além do grau de antropização encontrado nesta área (Pedroso de Moraes et al. 2010), a dimensão territorial, já que possui uma área bem maior que o referido Centro, o que também pode ser dito para o levantamento na Fazenda Cantagalo em São Paulo e, de modo semelhante, para o Parque Natural Municipal da Prainha no Rio de Janeiro e para a Fazenda Maximiano no Rio Grande do Sul, que, por apresentarem uma pequena área, naturalmente apresentariam uma riqueza menor de espécies com relação ao Morro do Chapéu, muito embora a quantidade de espécies para as áreas do Parque e das Fazendas seja bastante significativa. Em contrapartida a baixa similaridade com o litoral norte do Rio Grande do Sul parece claramente estar associada ao foco desse último levantamento, que objetivou listar apenas as Orchidaceae terrestres da área, além, é claro, das diferenças ambientais entre uma área litorânea e uma área serrana, já que a altitude, a temperatura e a pluviosidade são decisivos na determinação das formações vegetacionais e da flora local.

A similaridade florística entre floras está intrinsecamente relacionada às semelhanças entre as formações vegetais encontradas nas áreas. Os diferentes graus de similaridade apresentados nas comparações com o município de Morro do Chapéu, estão ligados ao fato desse município 
compartilhar especialmente representantes de floresta e campo rupestre com as áreas comparadas. Elementos da formação vegetal de floresta são mais abundantes que os dos demais tipos vegetacionais. Isso justificaria a predominância de espécies de floresta no município e o número de espécies em comum entre este e a maioria das áreas analisadas. Deve-se considerar, também, que espécies de outras formações vegetais, sobretudo dos cerrados, são frequentes na flora dos campos rupestres, que detém um número significativo de espécies em Morro do Chapéu. Alguns representantes desse tipo de vegetação chegam a ser compartilhados com as restingas e ambientes com condições edáficas e climáticas semelhantes às encontradas nas serras do Espinhaço (Rapini et al. 2008), onde os campos rupestres são predominates. No entanto, o fato de várias espécies da Cadeia do Espinhaço serem microendêmicas faz com que poucas sejam compartilhadas pelas porções mineiras e bainanas da Cadeia e, assim, a similaridade entre áreas, mesmo vizinhas, dentro do Espinhaço costuma ser muito baixa (Giulietti \& Pirani 1988; Rapini et al. 2002; Zappi et al. 2003; Conceição et al. 2005; Azevedo \& van den Berg 2007b). No presente estudo isso ocorreu, por exemplo, na comparação com a Chapada Diamantina. Além da significativa influência do tipo vegetacional, também é notável a interferência da dimensão territorial das áreas e da amostragem nos resultados confrontados, revelando como a discrepância amostral pode distorcer a percepção sobre relações florísticas, distribuição das espécies e riqueza de uma área.

\section{Chave para identificação das espécies de Orchidaceae registradas para o município de Morro do Chapéu}

1. Caule tipo cauloma.

2. Crescimento monopodial.

3. Folhas ovadas 53. Vanilla palmarum

3'. Folhas oblongas ou subuladas.

4. Folhas $1,5-2,5 \times$ ca. $0,1 \mathrm{~cm}$, ápice agudo 9. Campylocentrum aciculatum

4'. Folhas 3,5-8 × 1-1,5 cm, ápice emarginado 10. Campylocentrum micranthum

2'. Crescimento simpodial.

5. Folhas isoladas ou espiraladas.

6. Pedúnculo de inconspícuo até $7,5 \mathrm{~cm}$ compr.

7. Folha cilíndrica 5. Brassavola tuberculata

7'. Folha elíptica, linear, oblonga ou lanceolada.

8. Folha de ápice obtuso.

9. Labelo com margem dos lobos laterais fimbriada

9'. Labelo com margem inteira

2. Anathallis paranaensis

8'. Folha de ápice agudo ou retuso.

10. Pétalas inteiras; cálcar ausente.

11. Cauloma 11-14-foliado 40. Isochilus linearis

11'. Cauloma 1-foliado.

12. Sépalas laterais coalescentes na base 1. Acianthera ochreata subsp. ochreata 12'. Sépalas laterais livres entre si ..... 42. Octomeria hatschbachii 10’. Pétalas bipartidas; cálcar presente.

13. Labelo com segmentos laterais perpendiculares ao segmento mediano 35. Habenaria fluminensis

13'. Labelo com segmentos laterais deflexos.

14. Labelo com segmentos laterais de 3,7-5,2 mm compr. 38. Habenaria repens

14'. Labelo com segmentos laterais de 1-3 mm compr.

15. Labelo com segmento mediano de 3-3,9 $\times$ ca. $1,2 \mathrm{~mm}$ 37. Habenaria parviflora

15'. Labelo com segmento mediano de 7-8 $\times$ ca. 0,6 mm .. 36. Habenaria josephensis 
6'. Pedúnculo 17-57 cm compr.

16. Sépalas pilosas; labelo trilobado

44. Pelexia orthosepala

16'. Sépalas glabras; labelo inteiro.

17. Labelo ca. $4 \times 2 \mathrm{~mm}$ 47. Prescottia montana

17'. Labelo 1,3-2,7 × 0,8-1,7 mm.

18. Raque $18-29 \mathrm{~cm}$ compr.; labelo glabro

46. Prescottia leptostachya

18'. Raque ca. $6,5 \mathrm{~cm}$ compr.; labelo internamente piloso ... 48. Prescottia oligantha

5'. Folhas dísticas.

19. Coluna totalmente adnata abaxialmente ao labelo.

20. Labelo inteiro

25. Epidendrum orchidiflorum

20'. Labelo trilobado.

21. Labelo com lobos laterais oblongos

27. Epidendrum warasii

21'. Labelo com lobos laterais flabeliformes.

22. Planta 2-3 m compr.; labelo sem calosidade

24. Epidendrum cristatum

22 '. Planta 0,2-1,8 m compr., labelo com calosidade.

23. Labelo com lobo mediano triangular

3. Epidendrum cinnabarinum

23'. Labelo com lobo mediano sagitado 26. Epidendrum secundum

19'. Coluna livre.

24. Folhas com nervação reticulada; inflorescência 15-22 flores .... 28. Epistephium lucidum

1'. Caule tipo pseudobulbo.

24'. Folhas com nervação paralela; inflorescência 1-2 flores 51. Sobralia sessilis

25. Inflorescência lateral.

26. Pseudobulbo 1-foliado ou áfilo durante o período de floração.

27. Labelo inteiro.

28. Planta terrícola, 31-83,5 cm compr.; cálcar 5-8 mm compr.

28'. Planta epífita, 4,5-15,5 cm compr.; sem cálcar.

29. Galeandra beyrichii

29. Inflorescência com ca. 3 flores; sépalas laterais livres entre si; labelo com 2 calos centrais, arredondados

11. Capanemia thereziae

29'. Inflorescência multiflora; sépalas laterais coalescentes; labelo sem calosidade

41. Notylia pubescens

27'. Labelo trilobado.

30. Folha ovada

4. Bifrenaria tyrianthina

30'. Folha oblonga.

31. Labelo com calosidade pubescente

8. Bulbophyllum plumosum

31'. Labelo com calosidade glabro ou sem calosidade.

32. Sépalas glabras; lobo mediano arredondado a ovado

6. Bulbophyllum exaltatum

32'. Sépalas pilosas; lobo mediano cônico

7. Bulbophyllum manarae

26'. Pseudobulbos 2-10-foliados.

33. Pseudobulbo cônico ou fusiforme.

34. Folhas ovadas; flores diclinas; estaminódios presentes em forma de 2 antenas ....

12. Catasetum hookeri

34'. Folhas lanceoladas; flores monoclinas; estaminódios ausentes.

35. Pseudobulbo ca. $21 \times 3 \mathrm{~cm}$ 16. Cyrtopodium eugenii

35'. Pseudobulbo 46-72 $\times 2,5-3 \mathrm{~cm}$.

36. Planta epífita; labelo com lobo mediano reniforme

18. Cyrtopodium saintlegerianum

36'. Planta terrícola; labelo com lobo mediano cordiforme

17. Cyrtopodium flavum

33'. Pseudobulbo ovado.

37. Crescimento escandente; labelo inteiro

50. Rodriguezia obtusifolia

37'. Crescimento subcespitoso ou cespitoso; labelo trilobado. 
38. Sépalas laterais livres entre si 43. Oeceoclades maculata

38'. Sépalas laterais coalescentes na base.

39. Folha cilíndrica

52. Trichocentrum cebolleta

39'. Folha oblonga ou lanceolada.

40. Labelo com margem das axilas dos lobos laterais fimbriada 30. Gomesa barbata 40'. Labelo com margem inteira ou ondulada.

41. Planta 13-18,6 cm compr.; labelo com calosidade uniforme .... 33. Gomesa hookeri 41'. Planta 0,6-1,3 m compr.; labelo com calosidade verrucosa

42. Labelo com lobo mediano rômbico 32. Gomesa gravesiana 42'. Labelo com lobo mediano reniforme. 43. Labelo com lobo mediano bipartido 31. Gomesa blanchetii 43'. Labelo com lobo mediano tetrapartido 34. Gomesa varicosa

25'. Inflorescência apical.

44. Pseudobulbos cilíndricos; folhas elípticas a ovadas.

45. Labelo com lobos laterais retangulares 13. Cattleya amethystoglossa 45'. Labelo com lobos laterais oblanceolados.

46. Pedúnculo 13-19 cm compr., brácteas do pedúnculo lanceoladas ..... 15. Cattleya tenuis 46'. Pedúnculo 37-40 cm compr., brácteas do pedúnculo ovadas ..... 14. Cattleya elongata

44'. Pseudobulbos elípticos, ovados ou cônicos; folhas oblongas.

47. Labelo inteiro.

48. Planta epífita ca. $6 \mathrm{~cm}$ compr.; flores ressupinadas 39. Isabelia violacea

48'. Planta rupícola 16-27 cm compr.; flores não ressupinadas .... 49. Prosthechea moojenii 47'. Labelo trilobado.

49. Flores não ressupinadas; labelo com lobos laterais revolutos; coluna sem projeções ... 45. Polystachya estrellensis

49'. Flores ressupinadas; labelo com lobos laterais envolvendo a coluna; com projeções laterais, próximas ao ápice, em forma de ganchos.

50. Planta $38-48 \mathrm{~cm}$ compr.

51. Pedúnculo $26-30 \mathrm{~cm}$ compr.

20. Encyclia kundergraberi

51'. Pedúnculo 15,5-18 cm compr. 22. Encyclia patens

50'. Planta ca. $0,7-1,3 \mathrm{~m}$ compr.

52. Sépalas e pétalas patentes 19. Encyclia alboxanthina 52'. Sépalas e pétalas eretas levemente involutas 21. Encyclia oncidioides

1. Acianthera ochreata (Lindl.) Pridgeon \& M.W.Chase subsp. ochreata, Lindleyana 16 (4): 245. 2001.

Fig. 2a-j

Rupícola, 7-25 cm compr.; crescimento simpodial, cespitoso. Caule tipo cauloma $2-4 \times$ ca. $0,3 \mathrm{~cm}$, cilíndrico, 1-foliado. Folha paralelinérvea, 5-19 × ca. 0,5 cm, oblonga, verde, carnosa, ápice agudo. Inflorescência apical, 10-13 flores; pedúnculo 3-7,5 cm compr.; brácteas do pedúnculo $2-3,3-7 \mathrm{~mm}$ compr., oblongas; raque $2-5 \mathrm{~cm}$ compr.; brácteas florais $2-5 \mathrm{~mm}$ compr., rômbicas. Flores monoclinas, não ressupinadas, alaranjadas; pedicelo com ovário inconspícuo; sépalas eretas, lanceoladas, glabras, as laterais ca. $6 \times 2 \mathrm{~mm}$, coalescentes na base, a mediana ca. $5 \times 1,5 \mathrm{~mm}$; pétalas ca. $3 \times 1 \mathrm{~mm}$, eretas, inteiras, oblongas; labelo trilobado, alaranjado, carnoso, glabro, margem inteira, lobos laterais ca. 1,5 $\times 0,5 \mathrm{~mm}$, auriculados, dobrados para cima, lobo mediano 1-2 $\times$ ca. $1 \mathrm{~mm}$, arredondado; coluna ca. $2,5 \times 1 \mathrm{~mm}$, livre; antera 0,5-0,6 $\times 0,4-0,6 \mathrm{~mm}$, com apêndice apical; polínias 2, iguais, laminares.

Materiais selecionados: Morro do Chapéu, BA-052, 3.IV.1976, fl., G. Davidse et al. 11928 (HB); Buraco do Possidônio, 5.III.2008, fl., C.A. Bastos 139 (HUEFS); Cachoeira do Ferro Doido, 6.V.2007, fl., C.A. Bastos 7 (HUEFS); estrada para Bonito, 4.III.2008, fl., C.A. Bastos 125 (HUEFS); Fazenda Pé de Serra, 7.IX.2006, fr., J.L.Ferreira et al. 47 (HUEFS); Gruta da Boa Esperança, 14.XI.2008, fr., C.A. Bastos \& J. B. Pinto 277 (HUEFS); Morrão, 5.V.2007, fl., C.A. Bastos 1, 2 (HUEFS); Serra da Boa Esperança, 31.III.1991, fl., A.M. Miranda et al. 237 (ESA).

Essa subespécie é considerada endêmica do Nordeste brasileiro por Barros et al. (2010), 


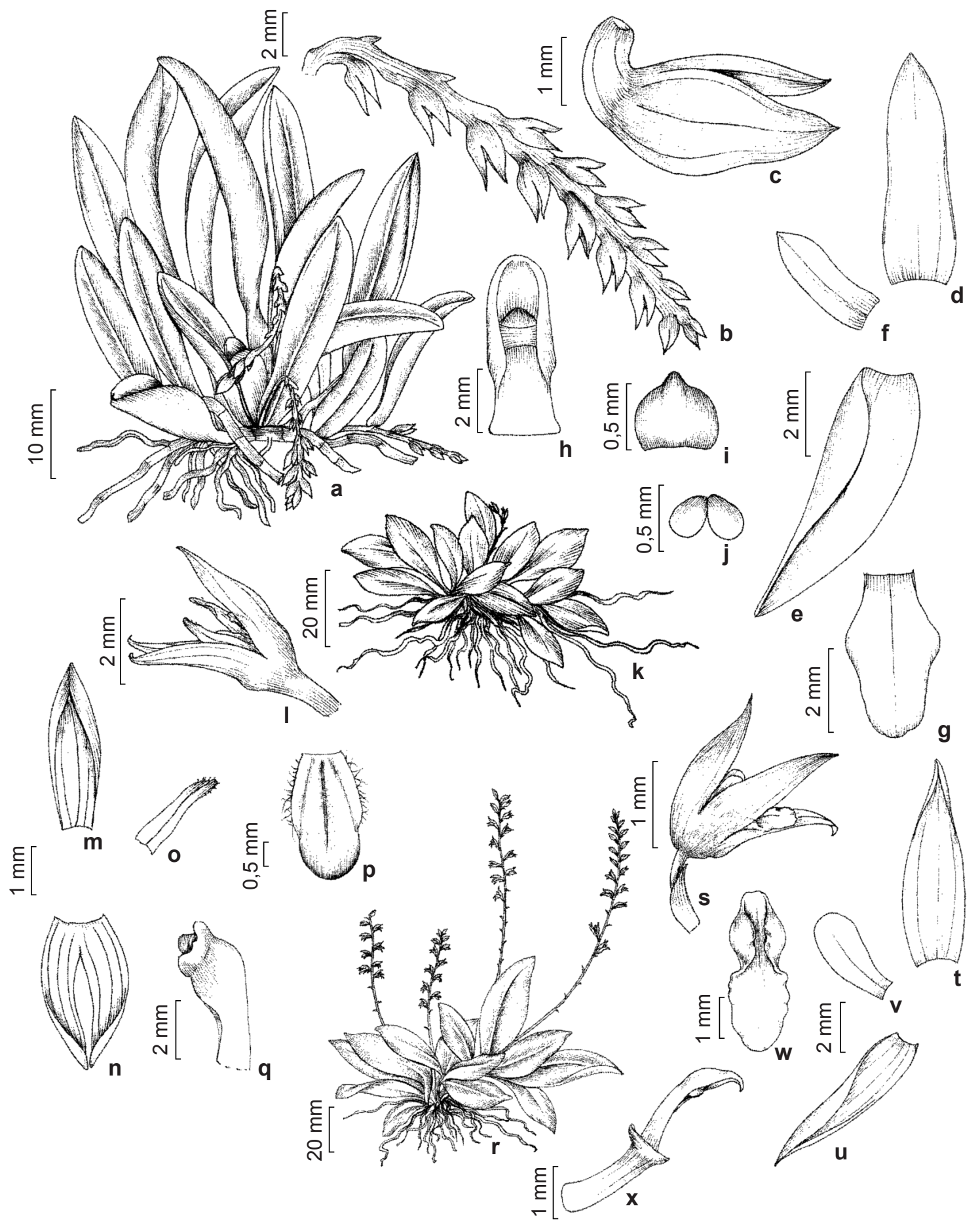

Figura 2 - a-j. Acianthera ochreata subsp. ochreata - a. hábito; b. inflorescência; c. flor; d. sépala dorsal; e. sépala lateral; f. pétala; g. labelo; h. coluna em vista ventral; i. antera; j. polínias. k-q. Anathallis paranaensis - k. hábito; 1. flor; m. sépala dorsal; n. sépalas laterais; o. pétala; p. labelo; q. coluna em vista lateral. r-x. Anathallis rubens - r. hábito; s. flor; t. sépala dorsal; u. sépala lateral; v. pétala; w. labelo; x. coluna em vista lateral. (a Pereira-Silva 8461, b-j Bastos 139; k-q Ribeiro 29; r-x Harley 22800). Figure 2 - a-j. Acianthera ochreata subsp. ochreata - a. habit; b. inflorescence; c. flower; d. dorsal sepal; e. lateral sepal; f. petal; g. lip; h. column seen from beneath; i. anther; j. pollinia. k-q. Anathallis paranaensis - k. habit; 1. flower; m. dorsal sepal; n. lateral sepals; o. petal; p. lip; q. column in side view. r-x. Anathallis rubens - r. habit; s. flower; t. dorsal sepal; u. lateral sepal; v. petal; w. lip; x. column in side view. (a Pereira-Silva 8461, b-j Bastos 139; k-q Ribeiro 29; r-x Harley 22800). 
ocorrendo nos estados da Paraíba, Pernambuco e Bahia, em domínios fitogeográficos de Caatinga, Cerrado e Mata Atlântica. Na Bahia é citada como Pleurothallis ochreata Lindl. para a Serra das Almas, Serra do Curral Feio, Serra do Rio de Contas, Serra do Sincorá, Morro do Chapéu e em Catolés, Jacobina, Lençóis, Mucugê, Palmeiras e Rio de Contas. No município de Morro do Chapéu é amplamente encontrada em afloramentos rochosos, nos campos rupestres, em grandes populações a pleno sol. Floresce em praticamente todos os meses do ano.

Acianthera ochreata subsp. cylindrifolia (Borba \& Semir) Borba foi descrita com base em diferenças morfológicas de caracteres vegetativos, diferenças químicas (perfil de alcalóides) e de distribuição geográfica em relação a Acianthera ochreata subsp. ochreata. A subespécie aqui considerada diferencia-se vegetativamente da Acianthera ochreata subsp. cylindrifolia pela presença de folhas carnosas conduplicadas, enquanto esta outra subespécie apresenta folhas cilíndricas sulcadas e ocorre apenas na Cadeia do Espinhaço em Minas Gerais (Borba et al. 2002; Borba 2003).

2. Anathallis paranaensis (Schltr.) Pridgeon \& M.W.Chase, Lindleyana 17 (2): 100. 2002.

Fig. 2k-q

Epífita, ca. 4 cm compr.; crescimento simpodial, cespitoso. Caule tipo cauloma ca. 0,6 × 0,1 cm, cilíndrico, 1-foliado. Folha paralelinérvea, ca. $2 \times 0,6 \mathrm{~cm}$, elíptica, vinácea na face adaxial, verde na abaxial, carnosa, ápice obtuso. Inflorescência apical, 2 flores; pedúnculo inconspícuo; bráctea do pedúnculo 1, inconspícua, ovada a lanceolada; raque ca. 0,5 cm compr. Flores monoclinas, ressupinadas, púrpuras; pedicelo com ovário inconspícuo; sépalas eretas, lanceoladas, glabras, as laterais ca. $3 \times 0,6 \mathrm{~mm}$, coalescentes na base, a mediana ca. $3 \times 1 \mathrm{~mm}$; pétalas ca. $2 \times 0,1$ $\mathrm{mm}$, eretas, inteiras, lineares; labelo subtrilobado, púrpura, membranáceo, glabro, lobos laterais inconspícuos, arredondados, explanados, margem fimbriada, lobo mediano ca. 2,5 × 1,5 mm, orbicular; coluna ca. $3 \times 2 \mathrm{~mm}$, livre.

Material examinado: Morro do Chapéu, Morrão, 9.VIII.2003, fl., P.L. Ribeiro et al. 29 (HUEFS).

Endêmica do Brasil, ocorre nos estados da Bahia, Rio de Janeiro, Paraná, Santa Catarina e Rio Grande do Sul, em áreas de Caatinga e Mata Atlântica. Na Bahia há registros em Mucugê e Rio de Contas, sendo citada como Pleurothallis paranaensis Schltr. No município de Morro do Chapéu, foi encontrada sobre tronco de árvores em mata de grotão em área de altitude superior a 900 m. Floresce no mês de agosto.

Anathallis paranaensis pode ser confundida com A. microphyta (Barb. Rodr.) C.O.Azevedo \& Van den Berg, mas difere desta por apresentar bainhas caulinares glabras e flores fasciculadas e sésseis sobre os ramicaules (Toscano de Brito \& Cribb 2005; Azevedo \& van den Berg 2007a).

3. Anathallis rubens (Lindl.) Pridgeon \& M.W.Chase, Lindleyana 16 (4): 250. 2001.

Fig. 2r-x

Rupícola, 20-34 cm compr.; crescimento simpodial, cespitoso. Caule tipo cauloma 1-4× ca. $0,2 \mathrm{~cm}$, cilíndrico, 1-foliado. Folha paralelinérvea, 5-8 × 1,5-2 cm, elíptica, verde, carnosa, ápice obtuso. Inflorescência apical, com mais de 30 flores; pedúnculo 6-7 cm compr.; brácteas do pedúnculo 4-7, 4-5 mm compr., oblongas; raque 12-12,5 cm compr.; brácteas florais ca. $3 \mathrm{~mm}$ compr., rômbicas. Flores monoclinas, ressupinadas, alaranjadas; pedicelo com ovário ca. 2 mm compr.; sépalas eretas, lanceoladas, glabras, as laterais ca. $6 \times 1,5 \mathrm{~mm}$, coalescentes na base, a mediana ca. $6 \times 1,5 \mathrm{~mm}$; pétalas ca. $3 \times 1 \mathrm{~mm}$, eretas, inteiras, oblongas; labelo trilobado, alaranjado, membranáceo, glabro, margem inteira, lobos laterais ca. $2 \times 0,5 \mathrm{~mm}$, rômbicos, involutos, lobo mediano ca. $2 \times 1,5 \mathrm{~mm}$, ovado; coluna ca. $2,5 \times$ $0,5 \mathrm{~mm}$, livre, com projeção apical falcada.

Materiais examinados: Morro do Chapéu, estrada para Bonito, 30.V.1980, fr., R.M. Harley 22800 (CEPEC); Morrão, 7.IV.2008, veg., C.A. Bastos \& C. van den Berg 165 (HUEFS).

Ocorre nos estados de Pernambuco, Bahia, Minas Gerais, São Paulo, Rio de Janeiro, Paraná, Santa Catarina e Rio Grande do Sul, em Caatinga, Cerrado e Mata Atlântica. Na Chapada Diamantina é encontrada em Catolés, Palmeiras e Rio de Contas, citada como Pleurothallis rubens Lindl. Em Morro do Chapéu foi encontrada em áreas de campo rupestre, vegetando em afloramentos rochosos. Floresce entre abril e maio.

4. Bifrenaria tyrianthina (Loudon) Rchb.f., Xenia Orchid. 1 (61): 223. 1858.

Rupícola, 3-42 cm compr.; crescimento simpodial, cespitoso. Caule tipo pseudobulbo 7-8 × 1-2 cm, cônico-tetrágono, 1-foliado. Folha paralelinérvea, $17-23 \times 6-6,5 \mathrm{~cm}$, ovada, verde, 
coriácea, ápice agudo. Inflorescência lateral, ca. 2 flores; pedúnculo $8-10 \mathrm{~cm}$ compr.; brácteas do pedúnculo $3-4$, ca. $3 \mathrm{~cm}$ compr., oblongas; raque 7,5-10 cm compr.; brácteas florais $1,7-2 \mathrm{~cm}$ compr., lanceoladas, paleáceas. Flores monoclinas, ressupinadas, púrpuras; pedicelo com ovário 4-6 cm compr.; sépalas eretas, oblongas, glabras, as laterais ca. 3,8 $\times 2,1 \mathrm{~cm}$, coalescentes na base, a mediana ca. $4 \times 2,6 \mathrm{~cm}$; pétalas ca. $3 \times 2 \mathrm{~cm}$, eretas, inteiras, ovadas; labelo trilobado, púrpura, coriáceo, piloso, margem inteira, com calosidade retangular, pilosa, lobos laterais ca. $2,3 \times 0,8 \mathrm{~cm}$, auriculados, involutos, lobo mediano ca. 1,5 × $2 \mathrm{~mm}$, lunado; cálcar ca. 3,7 $\times 0,5 \mathrm{~cm}$, cilíndrico; coluna ca. 1,6 $\times 0,6 \mathrm{~cm}$, livre.

Material examinado: Morro do Chapéu, Morrão, 11.XI.2001, fl., E.L. Borba 2068 (HUEFS).

É endêmica do Brasil, ocorrendo na Bahia, Minas Gerais, Espírito Santo, São Paulo e Rio de Janeiro, em Caatinga, Cerrado e Mata Atlântica. Habita os campos rupestres das porções mineira e baiana da Cadeia do Espinhaço, sendo encontrada na Chapada Diamantina nos municípios de Abaíra, Ibicoara, Morro do Chapéu, Palmeiras e Rio de Contas. É encontrada em Morro do Chapéu em afloramentos rochosos de campo rupestre. Floresce no mês de novembro.

Bifrenaria tyrianthina é comumente confundida com B. harrisoniae (Hook.) Rchb.f., mas é distinta dela pela presença de viscídio redondo e calo do labelo bilobado, enquanto $B$. harrisoniae apresenta viscídio truncado e calo trilobado, além de ter cálcar geralmente mais curto e possuir uma distribuição mais ampla que B. tyrianthina (Koehler \& Amaral 2004).

5. Brassavola tuberculata Hook., Bot. Mag. 56: t. 2878.1829.

Rupícola ou epífita, 17,5-32,5 cm compr.; crescimento simpodial, cespitoso. Caule tipo cauloma 2-10,5 × ca. 0,3 cm, cilíndrico, 1-foliado. Folha paralelinérvea, $15-22 \times 0,5 \mathrm{~cm}$, cilíndrica, verde, carnosa, ápice agudo. Inflorescência lateral, 2-3 flores; pedúnculo 1,5-2 cm compr.; brácteas do pedúnculo 1, 4-6 $\mathrm{mm}$ compr., rômbicas; raque 8-8,5 cm compr.; brácteas florais $1-4 \mathrm{~mm}$ compr., lanceoladas. Flores monoclinas, ressupinadas, amareladas; pedicelo com ovário 5,3-10,5 cm compr.; sépalas eretas, lanceoladas, glabras, as laterais ca. $3 \times 0,6 \mathrm{~mm}$, livres entre si, a mediana ca. $3,6 \times 0,6 \mathrm{~cm}$; pétalas ca. $3,4 \times 0,5 \mathrm{~cm}$, eretas, inteiras, lanceoladas; labelo inteiro, ca. $3 \times 2,7 \mathrm{~cm}$, deltóide, branco com centro amarelo, membranáceo, glabro, margem inteira; coluna ca. 1,2 $\times 0,3 \mathrm{~cm}$, livre, com projeções laterais, auriculares.

Material examinado: Morro do Chapéu, Cachoeira Pedro Bravo, 5.III.2008, fl., C.A. Bastos 154 (HUEFS). Material adicional: BRASIL. BAHIA: Mucugê, Parque Municipal de Mucugê, 26.XI.2002, fl., C. Azevedo \& R. Oliveira 165 (HUEFS).

Ocorre em Tocantins, Bahia, Sergipe, Minas Gerais, São Paulo, Rio de Janeiro, Paraná, Santa Catarina e Rio Grande do Sul, sendo encontrada em áreas de Cerrado, Caatinga e Mata Atlântica. $\mathrm{Na}$ Bahia é citada para Monte Santo e para os seguintes municípios da Chapada Diamantina: Abaíra, Ibicoara, Morro do Chapéu, Mucugê, Rio de Contas e Palmeiras. Em Morro do Chapéu foi encontrada vegetando entre rochas no alto de uma cachoeira e sobre tronco de árvores em áreas de floresta. Floresce de novembro a março.

6. Bulbophyllum exaltatum Lindl., Ann. Mag. Nat. Hist. 10: 186. 1842.

Fig. 3a-g

Rupícola ou terrícola, 24-98 cm compr.; crescimento simpodial, cespitoso. Caule tipo pseudobulbo 2-4,5 × 1-2 cm, ovóide-tetrágono, 1-foliado. Folha paralelinérvea, 5-10 × 1,5-2,5 $\mathrm{cm}$, oblonga, verde, carnosa, ápice agudo. Inflorescência lateral, 12-22 flores; pedúnculo 16$68 \mathrm{~cm}$ compr.; brácteas do pedúnculo $5-10,1-1,8$ cm compr., oblongas; raque $7,5-30 \mathrm{~cm}$ compr.; brácteas florais $4-8 \mathrm{~mm}$ compr., lanceoladas. Flores monoclinas, ressupinadas, brancas com máculas vináceas; pedicelo com ovário $4-5 \mathrm{~mm}$ compr.; sépalas eretas, lanceoladas, glabras, as laterais $1-1,3 \times 0,2-0,4 \mathrm{~cm}$, coalescentes na base, a mediana $0,8-1,4 \times 0,2-0,4 \mathrm{~cm}$; pétalas $3-4,5$ $\times 0,5-2 \mathrm{~mm}$, eretas, inteiras, lanceoladas; labelo trilobado, esverdeado suavemente pintalgado de vináceo, membranáceo, glabro, margem inteira, com calosidade elíptica, glabra, lobos laterais $1-1,5$ $\times$ ca. $1 \mathrm{~mm}$, ovados, eretos, lobo mediano $3,5-4,5$ $\times 2-3,5 \mathrm{~mm}$, arredondado a ovado; coluna 4,5-5 $\times$ ca. $1 \mathrm{~mm}$, livre, com projeções apicais corniforme. Materiais selecionados: Morro do Chapéu, Cachoeira do Ferro Doido, 28.VII.2005, fl., P.L. Ribeiro 176 (HUEFS); Cachoeira Pedro Bravo, 5.III.2008, fl., C.A. Bastos 158 (HUEFS); estrada para Bonito, 9.X.2007, fr., C.A. Bastos 109 (HUEFS); estrada para Feira de Santana, 7.VIII.2007, fl., C.A. Bastos 68 (HUEFS); estrada para Jacobina, 7.IV.2008, fl., C.A. Bastos 180 (HUEFS); Gruta da Boa Esperança, 14.XI.2008, fl., C.A. Bastos \& J.B. Pinto 276 (HUEFS); Morrão, 21.IV.2004, fl., P.L. Ribeiro 98 (HUEFS). 
Ocorre na Bahia, Minas Gerais, Espírito Santo, São Paulo e Santa Catarina, em áreas de Caatinga, Cerrado e Mata Atlântica. Pabst \& Dungs (1975) identificaram essa espécie como B. warmingianum Cogn. para Goiás. Na Bahia foi identificada como B. ipanemense Hoehne em Abaíra, Lençóis, Morro do Chapéu, Mucugê, Palmeiras, Piatã, Rio de Contas e na Serra das Almas. Em Morro do Chapéu foi encontrada em afloramentos rochosos de campo rupestre e cerrado. Floresce entre março e dezembro.

Bulbophyllum exaltatum corresponde a um complexo dentro do gênero Bulbophyllum Thouars e o maior problema taxonômico consiste na delimitação dos grupos B. involutum Borba, Semir \& F.Barros, B. ipanemense, B. longispicatum Cogn., B. geraense Rchb.f. ex Barb.Rodr. e $B$. warmigianum, que apresentam uniformidade vegetativa, sendo comumente separados pela morfologia floral, principalmente diferenças no labelo (Ribeiro et al. 2007; Borba \& Semir 1998). Ribeiro et al. (2007) realizaram um estudo a partir da análise genética e morfométrica de tais espécies, demonstrando a formação de dois grandes grupos onde as espécies da Bahia apresentam pouca diferenciação, indicando o binômio $B$. exaltatum como nome correto para as entidades relacionadas a tal complexo taxonômico, o que também foi sugerido por Smidt (2007) na revisão taxonômica para o gênero Bulbophyllum do Neotrópico.

\section{Bulbophyllum manarae Foldats, Acta Bot.} Venez. 3: 309. 1968.

Epífita, 17,5-20 cm compr.; crescimento simpodial, subcespitoso. Caule tipo pseudobulbo 0,5-1 × ca. 0,5 cm, ovóide-tetrágono, 1-foliado. Folha paralelinérvea, 2-3 $\times$ ca. $1 \mathrm{~cm}$, oblonga, verde, carnosa, ápice agudo. Inflorescência lateral, 11-15 flores; pedúnculo ca. $11 \mathrm{~cm}$ compr., verde; brácteas do pedúnculo $4,7-8 \mathrm{~mm}$ compr., oblongas; raque ca. $6 \mathrm{~cm}$ compr.; brácteas florais ca. $3 \mathrm{~mm}$ compr., lanceoladas. Flores monoclinas, não ressupinadas predominantemente vináceas; pedicelo com ovário ca. $1 \mathrm{~mm}$ compr.; sépalas eretas, ovadas, pilosas, as laterais $5-7 \times$ ca. $2 \mathrm{~mm}$, coalescentes na base, a mediana 6-7 $\times$ ca. $3 \mathrm{~mm}$; pétalas $3-4 \times$ ca. $1 \mathrm{~mm}$, eretas, inteiras, lanceoladas; labelo trilobado, vináceo a alaranjado, membranáceo, glabro, margem inteira, lobos laterais ca. 1,5 × 1,5 mm, auriculados, dobrados para cima, lobo mediano ca. $2 \times 1 \mathrm{~mm}$, cônico; coluna ca. $3 \times 2 \mathrm{~mm}$, livre; antera ca. $1 \times 1 \mathrm{~mm}$, com apêndice apical; polínias 4, 2 maiores e 2 menores entre si, ovais.
Material examinado: Morro do Chapéu, Cachoeira do Ferro Doido, XI.2001, fl., P.L. Ribeiro 113 (HUEFS).

No Brasil, ocorre nos estados de Roraima e Bahia, nos domínios fitogeográficos da Amazônia e em áreas de Caatinga. Na Chapada Diamantina é encontrarada em Morro do Chapéu e Rio de Contas. No município de Morro do Chapéu ocorre em floresta sobre o tronco de árvores. Floresce em novembro.

Pode ser confundida, pelos caracteres vegetativos, com as espécies relacionadas da seção Xiphizusa Rchb. f., como B. chloropterum Rchb.f., B. laciniatum Cogn. e B. plumosum Cogn., embora seja pouco relacionada a estas (Ribeiro et $a l$. 2005). É próxima de B. arianeae Fraga \& E. C. Smidt, diferindo desta pelo formato das pétalas e pilosidade do labelo (Smidt 2007).

8. Bulbophyllum plumosum Cogn., Fl. bras. 3 (5): 614. 1902.

Fig. 3h-o

Epífita, 9-15,5 cm compr.; crescimento simpodial, subcespitoso. Caule tipo pseudobulbo ca. $1 \times 0,6-1 \mathrm{~cm}$, ovóide-tetrágono, 1-foliado. Folha paralelinérvea, 3-5,5 × 0,5-1 cm, oblonga, verde, carnosa, ápice agudo. Inflorescência lateral, 5-9 flores; pedúnculo 4-8,5 cm compr.; brácteas do pedúnculo 2-4, 5-8 mm compr., oblongas; raque 2-6,5 cm compr.; brácteas florais 3-4 mm compr., ovadas. Flores monoclinas, ressupinadas, vináceas; pedicelo com ovário ca. 1,5 mm compr.; sépalas eretas, lanceoladas, pubescentes, as laterais 1-1,6 $\times 0,1-0,3 \mathrm{~cm}$, coalescentes na base, a mediana $1-1,6 \times$ ca. $0,2 \mathrm{~cm}$; pétalas ca. $4 \times 1,5 \mathrm{~mm}$, eretas, frimbriada na metade para o ápice, oblongas; labelo trilobado, vináceo, membranáceo, glabro, margem inteira, lobos laterais ca. $3,5 \times 0,5 \mathrm{~mm}$, auriculados, dobrados para cima, lobo mediano 6-8 $\times 0,6-2 \mathrm{~mm}$, espatulado, calosidade elíptica, longitudinalmente fendida, pubescente; coluna ca. 2,5 × $1 \mathrm{~mm}$, livre, com projeções apicais corniformes e laterais lineares; antera $1 \times 0,8 \mathrm{~mm}$, com apêndice apical; polínias 2, iguais, ovais.

Materiais examinados: Morro do Chapéu, Cachoeira do Ferro Doido, 9.III.2003, fl., L.P. Queiroz 7688 (HUEFS); Fazenda Guariba, VII.2008, fl., C.A. Bastos \& C. van den Berg 191 (HUEFS)

Material adicional: BRASIL. BAHIA: Abaíra, 31.III.1994, fl., W. Ganev 3003 (HUEFS).

Considerada endêmica do Brasil por Barros et al. (2010), ocorre na Bahia, Goiás, Distrito Federal, Minas Gerais, Espírito Santo, São Paulo e Rio Grande do Sul, em Caatinga, Cerrado e Mata Atlântica. Angely (1965) cita-a ainda para o Paraná. 

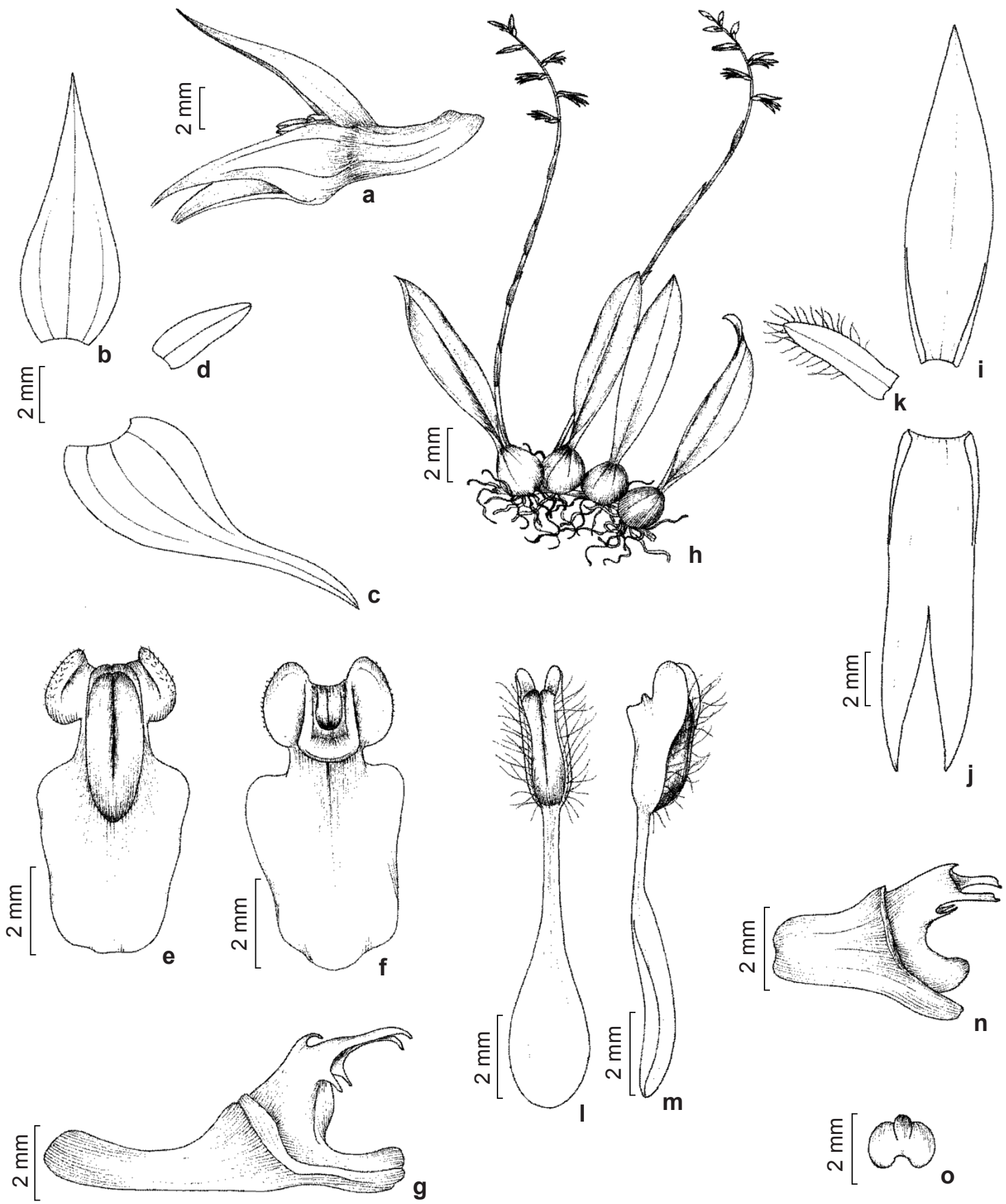

Figura 3 - a-g. Bulbophyllum exaltatum - a. flor; b. sépala dorsal; c. sépala lateral; d. pétala; e. labelo em vista ventral; f. labelo em vista dorsal; g. ovário e coluna em vista lateral. h-o. Bulbophyllum plumosum - h. hábito; i. sépala dorsal; j. sépalas laterais; $\mathrm{k}$. pétala; 1 . labelo em vista ventral; m. labelo em vista lateral; $\mathrm{n}$. ovário e coluna em vista lateral; o. antera em vista dorsal. (a-g Bastos 119; h-o Ribeiro 48).

Figure 3 - a-g. Bulbophyllum exaltatum - a. flower; b. dorsal sepal; c. lateral sepals; d. petal; e. lip seen from beneath; f. lip seen from above; g. ovary and column in side view. h-o. Bulbophyllum plumosum - h. habit; i. dorsal sepal; j. lateral sepals; k. petal; 1. lip seen from beneath; m. lip in side view; n. ovary and column in side view; o. anther seen from above. (a-g Bastos 119; h-o Ribeiro 48). 
$\mathrm{Na}$ Bahia há registros para dois municípios da Chapada Diamantina: Abaíra e Morro do Chapéu. No município de Morro do Chapéu foi encontrada em áreas de floresta sobre tronco de árvore. Floresce de março a agosto.

Segundo Ribeiro et al. (2005) é comumente confundida com $B$. laciniatum Cogn. e $B$. chloropterum Rchb.f., mas difere destas pelas pétalas lanceoladas e labelo com calo. Para Smidt (2007) é muito próxima de B. gehrtii E.C.Smidt $\&$ Borba, que possui folhas lineares e flores com parte distal do labelo côncava e pilosidade apenas na junção da parte basal com a distal, enquanto que em B. plumosum a parte distal do labelo é plana e a pilosidade ocorre apenas nas margens da parte basal.

\section{Campylocentrum aciculatum (Rchb.f. \& Warm.)} Cogn., Fl. bras. 3 (6): 516. $1906 . \quad$ Fig. 4a-i Epífita, 31,5-75 cm compr.; crescimento monopodial. Caule tipo cauloma 30-73,5 $\times$ ca. 0,2 cm, cilíndrico, 7-15-foliado. Folhas com nervação paralela, 1,5-2,5 × ca. 0,1 cm, espiraladas, subuladas, verdes, membranáceas, ápice agudo. Inflorescência axilar, 4-6 flores; pedúnculo $0,1-0,4 \mathrm{~cm}$ compr.; bráctea do pedúnculo 1 , ca. $1 \mathrm{~mm}$ compr., rômbica; raque ca. $0,5 \mathrm{~cm}$ compr.; brácteas florais ca. $1 \mathrm{~mm}$ compr., lanceoladas. Flores monoclinas, não ressupinadas, brancas; pedicelo com ovário ca. $1 \mathrm{~mm}$ compr.; sépalas eretas, ovadas, glabras, as laterais ca. 1,5 $\times 0,5 \mathrm{~mm}$, livres entre si, a mediana ca. $2 \times 1 \mathrm{~mm}$; pétalas ca. $1 \times 0,5 \mathrm{~mm}$, eretas, inteiras, lanceoladas; labelo trilobado, branco, membranáceo, glabro, margem inteira, lobos laterais ca. $1 \times 0,5 \mathrm{~mm}$, triangulares, suavemente involutos, lobo mediano ca. $0,5 \times 0,5$ $\mathrm{mm}$, triangular; cálcar ca. $3 \times 1 \mathrm{~mm}$, cilíndrico; coluna ca. $1 \times 1 \mathrm{~mm}$, livre, com projeção apical cordata; antera $0,8-0,9 \times 0,5-0,7 \mathrm{~mm}$, projeção membranosa; polínias 2, iguais, circulares.

Materiais examinados: Morro do Chapéu, estrada para Buraco do Possidônio, 7.IV.2008, fl., C.A. Bastos 178 (HUEFS); Fazenda Guariba, 8.IV.2008, fl., C.A. Bastos 182 (HUEFS).

É uma espécie endêmica do Brasil, ocorrendo nos estados da Bahia, Minas Gerais e Rio de Janeiro, em áreas de Caatinga, Cerrado e Mata Atlântica. Na Bahia há registro para a Chapada Diamantina, em Catolés. Foi encontrada no município de Morro do Chapéu sobre tronco de árvore em área de floresta. Floresce nos meses de março e abril.

Esta espécie é similar a C. micranthum (Lindl.) Maury, que também ocorre em Morro do Chapéu, mas difere desta principalmente pelos caracteres vegetativos, sendo que $C$. aciculatum possui folhas subuladas, de ápice agudo e C. micranthum tem folhas oblongas a ovadas, de ápice emarginado. As flores de $C$. aciculatum não são ressupinadas, enquando $C$. micranthum apresenta flores ressupinadas.

10. Campylocentrum micranthum (Lindl.) Maury, J. Bot. (Morot). 3: 273. 1889.

Epífita, ca. 7-38 cm compr.; crescimento monopodial. Caule tipo cauloma 7-31 × ca. 0,4 cm, cilíndrico, 4-17-foliado. Folhas com nervação paralela, 3,5-8 × 1-1,5 cm, espiraladas, oblongas, verdes, carnosas, ápice emarginado. Inflorescência axilar, ca. 17 flores; pedúnculo ca. 0,2 cm compr.; bráctea do pedúnculo 1 , ca. $1 \mathrm{~mm}$ compr., ovada; raque 1,5-2 cm compr.; brácteas florais ca. $1 \mathrm{~mm}$ compr., ovadas. Flores monoclinas, ressupinadas, esbranquiçadas; pedicelo com ovário ca. $1 \mathrm{~mm}$ compr.; sépalas eretas, oblongas, glabras, as laterais ca. $3,5 \times 1 \mathrm{~mm}$, livres entre si, a mediana ca. 3,5 × 1 mm; pétalas ca. $3 \times 1 \mathrm{~mm}$, eretas, inteiras, oblongas; labelo trilobado, alvacento, membranáceo, glabro, margem inteira, lobos laterais ca. $0,1 \times 1 \mathrm{~mm}$, triangulares, involutos, lobo mediano ca. $1 \times 1 \mathrm{~mm}$, triangular; cálcar ca. $2 \times 1 \mathrm{~mm}$, cilíndrico; coluna ca. $1 \times 1 \mathrm{~mm}$, livre; antera $0,07 \times 0,06 \mathrm{~mm}$, sem apêndice apical; polínias 2 , iguais, elípticas.

Materiais examinados: Morro do Chapéu, estrada para Bonito, 23.VII.2008, fr., C.A. Bastos \& J. B. Pinto 244 (HUEFS); estrada de chão a partir da BA 052, 17.VI.2008, fr., C.A. Bastos 221 (HUEFS).

Materiais adicionais: BRASIL. BAHIA: Cachoeira, Estação da Mata, X.1980, fl., Grupo Pedra do Cavalo 809 (HUEFS); Ipirá, Fazenda Recreio, 4.X.1986, fl., L.P. Queiroz et al. 971 (HUEFS); Mucugê, Parque Municipal de Mucugê, 27.I.2003, fl., C. Azevedo 173 (HUEFS).

Ocorre do Norte ao Sudeste do Brasil, nos mais variados tipos vegetacionais. Na Bahia foi registrada nos municípios de Palmeiras, Rio de Contas e Mucugê. No município de Morro do Chapéu foi coletada em área de floresta sobre tronco de árvores. Encontrada com flores em junho e julho.

11. Capanemia therezae Barb.Rodr., Gen. Sp. Orch. Nov. 2: 244. $1877 . \quad$ Fig. 4j-r

Epífita, 4,5-5,5 cm compr.; crescimento simpodial, subcespitoso. Caule tipo pseudobulbo ca. $0,5 \times 0,5 \mathrm{~cm}$, ovado, 1-foliado. Folha paralelinérvea, ca. $2,5 \times 0,5 \mathrm{~cm}$, lanceolada, verde, carnosa, ápice agudo. Inflorescência lateral, ca. 3 flores; pedúnculo ca. $1 \mathrm{~cm}$ compr.; bráctea 


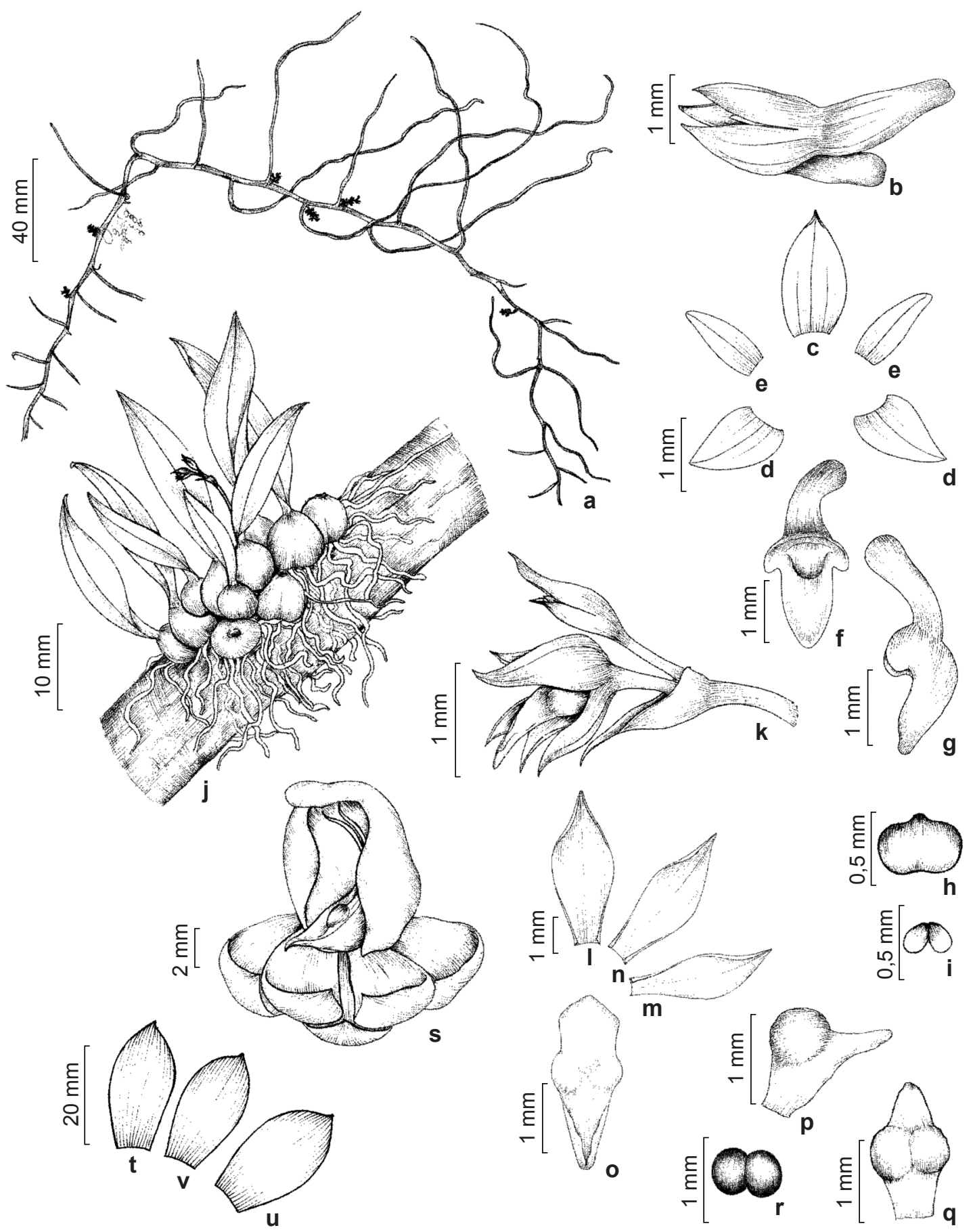

Figura 4 -a-i. Campylocentrum aciculatum - a. hábito; b. flor; c. sépala dorsal; d. sépalas laterais; e. pétalas; f. labelo e ovário em vista ventral; g. labelo e ovário em vista lateral; h. antera em vista dorsal; i. polínias. j-r. Capanemia therezae - j. hábito; k. flor; 1 . sépala dorsal; m. sépala lateral; $n$. pétala; o. labelo; p. coluna em vista lateral; q. coluna em vista dorsal; r. polínias. s-v. Catasetum hookeri-s. flor; t. sépala dorsal; u. sépala lateral; v. pétala. (a Bastos 182, b-i Bastos 130; j-r Andrade-Lima 6136; s-v Nonato 954).

Figure 4 - a-i. Campylocentrum aciculatum - a. habit; b. flower; c. dorsal sepal; d. lateral sepals; e. petal; f. lip and ovary seen from beneath; g. lip and ovary in side view; h. anther seen from above; i. pollinia. j-r. Capanemia therezae - j. habit; k. flower; 1. dorsal sepal; m. lateral sepal; n. petal; o. lip; p. column in side view; q. column seen from above; r. pollinia. s-v. Catasetum hookeri - s. flower; t. dorsal sepal; u. lateral sepal; v. petal. (a Bastos 182, b-i Bastos 130; j-r Andrade-Lima 6136; s-v Nonato 954). 
do pedúnculo 1, ca. $3 \mathrm{~mm}$ compr., lanceolada; raque ca. $0,5 \mathrm{~cm}$ compr.; brácteas florais ca. $2 \mathrm{~mm}$ compr., ovadas. Flores monoclinas, ressupinadas, levemente esverdeadas; pedicelo com ovário 1-2 mm compr.; sépalas eretas, lanceoladas, glabras, as laterais $2-3 \times 0,5-1 \mathrm{~mm}$, livres entre si, a mediana 1,5-3 × 0,5-1 mm; pétalas $1,5-3 \times 0,6-1 \mathrm{~mm}$, eretas, inteiras, lanceoladas; labelo inteiro, 1,52,5 × 0,6-1,5 mm, sagitado, branco a esverdeado, membranáceo, glabro, margem inteira, com 2 calos centrais, arredondados, glabros; coluna ca. $2 \times 1 \mathrm{~mm}$, livre, com projeção apical triangular, antera $0,4 \times 0,2 \mathrm{~mm}$, sem apêndice apical; polínias 2 , iguais, globosas.

Material examinado: Morro do Chapéu, Morrão, 25.X.1970, fl., Andrade-Lima 6136 (HUEFS); 13.XI.2008, fl., C.A. Bastos \& J. B. Pinto 267 (HUEFS).

É endêmica do Brasil e ocorre em Pernambuco, Minas Gerais, São Paulo, Rio de Janeiro, Paraná, Santa Catarina e Rio Grande do Sul, em áreas de Cerrado e Mata Atlântica. Foi recentemente citada como espécie nova para a Bahia por Buzatto \& Machado (2011) com base em espécime coletado no município de Morro do Chapéu, o que já havia sido mencionado no trabalho de Bastos (2009) com base no mesmo material. Ocorre nesse município em mata de grotão sobre tronco de árvores. Encontrada com flor em outubro.

12. Catasetum hookeri Lindl., Bot. Reg. 10: sub t. 840. 1824.

Fig. $4 \mathrm{~s}-\mathrm{v}$

Epífita, 40-55,5 cm compr.; crescimento simpodial, subcespitoso. Caule tipo pseudobulbo 10-16 × 1,5-2 cm, cônico, 2-8-foliado. Folhas com nervação paralela, 21-32 × 4-6 cm, dísticas, ovadas, verdes, membranáceas, ápice agudo. Inflorescência lateral, ca. 13 flores; pedúnculo 16-23 cm compr.; brácteas do pedúnculo 5 , ca. 1 cm compr., oblongas; raque $14-14,5 \mathrm{~cm}$ compr.; brácteas florais ca. $1 \mathrm{~mm}$ compr., oblongas. Flores diclinas; flores estaminadas não ressupinadas, verdes; pedicelo com ovário 2,7-3 cm compr.; sépalas eretas, ovadas, glabras, as laterais ca. $2,5 \times 1,5 \mathrm{~cm}$, livres entre si, a mediana ca. 2,3 $\times 1 \mathrm{~cm}$; pétalas ca. $2,5 \times 1,5 \mathrm{~cm}$, eretas, inteiras, ovadas; labelo trilobado, esverdeado, crasso-carnoso, glabro, margem inteira, lobos laterais ca. $1 \times 1 \mathrm{~cm}$, orbiculares, involutos, lobo mediando ca. 1,2 $\times$ $1,2 \mathrm{~cm}$, ovado; coluna ca. $1,3 \times 0,5 \mathrm{~cm}$, livre, com projeções lineares; estaminódios presentes em forma de 2 antenas com ca. $1,5 \mathrm{~cm}$ compr., antera $71 \times 28 \mathrm{~mm}$, com apêndice apical; polínias 2 , iguais, ovais; flores pistiladas não ressupinadas, verdes; pedicelo com ovário ca. 1,5 × $0,3 \mathrm{~cm}$; sépalas ovadas, glabras, as laterais $0,7-1,3 \times 0,6-0,8$ $\mathrm{cm}$, livres entre si, a mediana $0,6-1 \times$ ca. $0,5 \mathrm{~cm}$; pétalas $0,7-1,3 \times 0,4-0,8 \mathrm{~cm}$, inteiras, ovadas; labelo inteiro, $0,7-1,8 \times 0,7-1,5 \mathrm{~cm}$, calceolado, verde, carnoso, glabro, margem inteira; coluna ca. $0,5 \times 0,3-0,5 \mathrm{~cm}$, livre.

Materiais examinados: Morro do Chapéu, BA 426, 4.VIII.2001, fl., F.R. Nonato 953, 954 (HUEFS); estrada para Bonito, 16.VI.2008, fl., C.A. Bastos 209 (HUEFS); Miraserra, 16.VI.2008, fr., C.A. Bastos 206 (HUEFS).

Segundo Barros et al. (2010), é uma espécie endêmica do Brasil com ocorrência nos estados do Pará, Maranhão, Bahia, Minas Gerais, Espírito Santo, São Paulo e Rio de Janeiro, nos domínios fitogeográficos da Amazônia, Caatinga e Mata Atlântica. Freitas et al. (2011) cita-a ainda para o estado do Ceará. Na Chapada Diamantina há registros nos municípios de Abaíra, Andaraí, Lençóis, Morro do Chapéu, Palmeiras e Piatã. No município de Morro do Chapéu foi encontrada em áreas de caatinga sobre palmeira licuri: Syagrus coronata (Mart.) Becc. Encontrada com flor de junho a agosto.

Essa espécie é muito semelhante a C. luridum (Link.) Lindl. que também ocorre como epífita em licuri, mas $C$. hookeri parece ocupar ambientes mais úmidos do que $C$. luridum, e floresce sempre no início da brotação, quando aparecem os ápices das folhas, mas o novo pseudobulbo ainda não é visível, enquanto $C$. luridum floresce após o broto já estar bem desenvolvido em um pseudobulbo (Bastos \& van den Berg no prelo). Catasetum hookeri possui flores estaminadas não ressupinadas e labelo com lobo mediano oval, enquanto $C$. luridum apresenta flores estaminadas ressupinadas e lobo mediano orbicular. As flores pistiladas dessas espécies são muito semelhantes e pouco informativas, como acontece em todo o gênero. As flores estaminadas, com estruturas em forma de antenas na face ventral da coluna, são as que fundamentam a taxonomia de Catasetum L.C.Rich. ex Kunth (Bicalho 1960; Toscano de Brito \& Cribb 2005).

13. Cattleya amethystoglossa Linden \& Rchb.f. ex Warner, Sel. Orch. ser. 1: t. 2. 1862.

Terrícola, ca. $70 \mathrm{~cm}$ compr.; crescimento simpodial, cespitoso. Caule tipo pseudobulbo ca. 44 $\times 2 \mathrm{~cm}$, cilíndrico, 2-foliado. Folhas com nervação paralela, ca. $21 \times 8 \mathrm{~cm}$, dísticas, elípticas, verdes, carnosas, ápice obtuso. Inflorescência apical, ca. 7 flores; pedúnculo ca. $10 \mathrm{~cm}$ compr.; bráctea do 
pedúnculo 1, ca. $5 \mathrm{~mm}$ compr., rômbica; raque ca. 14,5 cm compr.; brácteas florais ca. $5 \mathrm{~mm}$ compr., lanceoladas. Flores monoclinas, ressupinadas, predominantemente róseas com máculas magenta; pedicelo com ovário ca. 4,7 cm compr.; sépalas eretas, oblongas, glabras, as laterais ca. 5,3 $\times 2$ $\mathrm{cm}$, livres entre si, a mediana ca. $6 \times 2 \mathrm{~cm}$; pétalas ca. $6 \times 2,5 \mathrm{~cm}$, eretas, inteiras, oblongas; labelo trilobado, róseo com extremidade dos lobos laterais e lobo mediano róseo escuro, carnoso, com superfície papilhosa, margem inteira, lobos laterais ca. $3 \times 1,2 \mathrm{~cm}$, retangulares, dobrados sobre a coluna, lobo mediano ca. $2,5 \times 3 \mathrm{~cm}$, reniforme; coluna ca. $2,3 \times 1 \mathrm{~cm}$, livre; antera $5 \times 5 \mathrm{~mm}$, sem apêndice apical; polínias 4, iguais, elípticas.

Material examinado: Morro do Chapéu, estrada para a Fazenda Angico, 21.VI.2005, fl., C. van den Berg 1626 (HUEFS).

Embora tenha sido considerada endêmica da Bahia por Barros et al. (2010), já foi citada também para os estados de Pernambuco e Minas Gerais (Fowlie 1977 apud Toscano de Brito \& Cribb 2005). Embora Barros et al. (2010) considerem essa espécie exclusivamente de Mata Atlântica, na Bahia há registros em áreas de Mata Atlântica, Caatinga e florestas estacionais no sul, planícies centrais e nordeste da Chapada Diamantina (Cruz et al. 2003), onde foi encontrada no município de Campo Formoso. Em Morro do Chapéu foi coletada em área de caatinga sobre solo arenoso. O material examinado floresceu em cultivo no mês de junho.

14. Cattleya elongata Barb.Rodr., Gen. Sp. Orchid.1: 72. 1877.

Terrícola, 57-91,5 cm compr.; crescimento simpodial, cespitoso. Caule tipo pseudobulbo 13-38 × 1-1,5 cm, cilíndrico, 2-foliado. Folhas com nervação paralela, 8-15 × 3-5 cm, dísticas, elípticas, verdes, coriáceo-carnosas, ápice obtuso. Inflorescência apical, 3-4 flores; pedúnculo 37-40 cm compr.; brácteas do pedúnculo $3-4,0,4-1 \mathrm{~cm}$ compr., ovadas; raque ca. $12,5 \mathrm{~cm}$ compr.; brácteas florais 4-7 mm compr., lanceoladas. Flores monoclinas, ressupinadas, predominantemente vermelhoamarronzadas; pedicelo com ovário ca. $4,5 \mathrm{~cm}$ compr.; sépalas eretas, oblongas, glabras, as laterais $3,5-4 \times 1-1,6 \mathrm{~cm}$, livres entre si, a mediana 4,3-5 $\times 1-1,3 \mathrm{~cm}$; pétalas $4,2 \times 0,8-1 \mathrm{~cm}$, eretas, inteiras, oblongas; labelo trilobado, rosa, carnoso, glabro, margem inteira, lobos laterais 2,5-3,4 × 1-1,6 cm, oblanceolados, dobrados sobre a coluna, lobo mediano 1,8-2,6 × 2-3,4 cm, reniforme; coluna
2,5-3 × ca. $1 \mathrm{~cm}$, livre; antera 4,8-5 × 4,6-5,1 mm, sem apêndice apical; polínias 2 , iguais, elípticas. Materiais examinados: Morro do Chapéu, Cachoeira do Ferro Doido, 9.IV.2005, fl., D.T. Cruz 25 (HUEFS); Cachoeira Pedro Bravo, 5.III.2008, fl., C.A. Bastos 159 (HUEFS); Goiabeira do Brejo de Zacarias, 28.V.2005, fl., F. França et al. 5227 (HUEFS); Serra da Boa Esperança, 11.III.2002, fl., W.W. Thomas 12899 (CEPEC).

Endêmica do Brasil, ocorre em Pernambuco, Bahia e Minas Gerais, em Caatinga e Cerrado. Na Bahia é referida apenas para a Chapada Diamantina em Abaíra, Andaraí, Ibicoara, Morro do Chapéu, Lençóis, Mucugê, Palmeiras, Rio de Contas e Seabra. Em Morro do Chapéu é encontrada em afloramentos rochosos de mata ciliar. Floresce entre março e julho.

15. Cattleya tenuis Campacci \& P.L.Vedovello, Cir. Pau. Orquid. 1: 1. 1983.

Epífita, 40-86 cm compr.; crescimento simpodial, subcespitoso. Caule tipo pseudobulbo $26-57 \times 0,5-0,6 \mathrm{~cm}$, cilíndrico, 2-foliado. Folhas com nervação paralela, $12-14,5 \times 3,5-5 \mathrm{~cm}$, dísticas, elípticas a ovadas, verdes, coriáceocarnosas, ápice obtuso. Inflorescência apical, 1-3 flores; pedúnculo 13-19 cm compr.; brácteas do pedúnculo 2-3, 3-5 mm compr., lanceoladas; raque ca. 2,5 cm compr.; brácteas florais $3-5 \mathrm{~mm}$ compr., lanceoladas. Flores monoclinas, ressupinadas, predominantemente verde bronzes; pedicelo com ovário 3,3-4,7 cm compr.; sépalas eretas, oblongas, glabras, as laterais $4,5-5 \times 1,5 \mathrm{~cm}$, livres entre si, a mediana 4,8-6,5 × 1,2-1,8 cm; pétalas 4,5-5,4 $\times$ 1,4-2,4 cm, eretas, inteiras, ovadas; labelo trilobado, lobos laterais branco-róseos e mediano magenta com uma região periférica lilás-claro, carnoso, com superfície papilhosa, margem inteira, lobos laterais 3-3,5 $\times 1-1,3 \mathrm{~cm}$, oblanceolados, dobrados sobre a coluna, lobo mediano 2-2,4 $\times 2-2,6 \mathrm{~cm}$, reniforme; coluna ca. 2,5 × 0,7-0,9 cm, livre.

Material examinado: Morro do Chapéu, arredores de Morro do Chapéu, II.1982, fl., A. Martinho (SP 274802). Materiais adicionais: BRASIL. BAHIA: Abaíra, distrito de Catolés, 13.IV.1992, fl., W. Ganev 133 (HUEFS); Palmeiras, 10.IV.2002, fl., Jurandir (HUEFS 63117); Rio de Contas, estrada para Jussiape, 8.III.1994, fl., R.M. Harley et al. 55067 (HUEFS). PERNAMBUCO: sem local, 6.III.1982, fl., A. Martinho (Holótipo: SP 274802).

Ocorre em áreas de Caatinga e Cerrado. É endêmica da Bahia, aparentemente da Chapada Diamantina, onde pode ser encontrada nos municípios de Abaíra, Palmeiras e Rio de Contas. Pode estar extinta em Morro do Chapéu (Cruz 
et al. 2003), não tendo sido coletada durante o desenvolvimento deste trabalho. O material examinado corresponde ao holótipo, com flor em fevereiro.

Lembra Cattleya elongata e quando ocorrem em uma mesma área podem cruzar produzindo o híbrido C. × tenuata (Braem 1995 apud Toscano de Brito \& Cribb 2005). É similar a Cattleya bicolor Lindl. mas difere desta pela presença de lobos laterais do labelo (Castro Neto \& Campacci 2006). Esta espécie foi descrita originalmente a partir de material em posse de colecionadores em São Paulo, e tentando verificar detalhadamente a origem das plantas, nos veio uma indicação informal de que o holótipo poderia ter um erro de localidade, sendo originalmente de Seabra. Isso poderia explicar o insucesso em localizar uma planta tão conspícua após todo o esforço amostral no município.

16. Cyrtopodium eugenii Rchb.f. \& Warm., Otia Bot. Hamburg. 2: 89. 1881.

Terrícola, 67,5-97 cm compr.; crescimento simpodial cespitoso. Caule tipo pseudobulbo ca. 21 $\times 3 \mathrm{~cm}$, fusiforme, 8-foliado. Folhas com nervação paralela, na antese ca. $18 \times 0,5 \mathrm{~cm}$, dísticas, lanceoladas, verdes, membranáceas, ápice agudo. Inflorescência lateral, ca. 15 flores; pedúnculo 51,5-69,5 cm compr.; brácteas do pedúnculo 2-4, 2,2-2,7 cm compr., lanceoladas; raque 21-28 cm compr.; brácteas florais 1,6-2,3 cm compr., lanceoladas. Flores monoclinas, ressupinadas, esverdeadas com máculas vináceas; pedicelo com ovário 2,1-2,2 cm compr.; sépalas eretas, lanceoladas, glabras, as laterais ca. 1,6 ×0,8 cm, livres entre si, a mediana ca. $2 \times 0,7 \mathrm{~cm}$; pétalas ca. $1,5 \times 0,8 \mathrm{~cm}$, eretas, inteiras, lanceoladas; labelo trilobado, amarelo, membranáceo, glabro, margem inteira, com calosidade orbicular verrucosa, glabra, lobos laterais ca. $6 \times 4 \mathrm{~mm}$, auriculados, eretos, lobo mediano ca. $0,7 \times 1 \mathrm{~cm}$, pandurado; coluna ca. $9 \times 3 \mathrm{~mm}$, livre; antera $2 \times 1 \mathrm{~mm}$, com apêndice apical; polínias 2, iguais, ovais.

Material examinado: Morro do Chapéu, Morrão, 5.XI.2007, fl., C.A. Bastos 94 (HUEFS).

Material adicional: BRASIL. BAHIA: Abaíra, caminho Boa Vista para Bicota, 9.VII.1995, fl., F. França et al. 1309 (HUEFS).

Barros et al. (2010) citaram esta espécie para a Bahia, Mato Grosso, Goiás, Distrito Federal e Minas Gerais, em áreas de Caatinga e Cerrado. Há registros, ainda, para o Paraná (Pabst \& Dungs 1975) e São Paulo (Ferreira \& Pansarin 2010). Na Bahia foi encontrada na zona costeira em área de restinga (Harley \& Mayo 1980) e na Chapada Diamantina, em Palmeiras e Rio de Contas. Em Morro do Chapéu foi encontrada em área de Caatinga, exposta ao sol, com flor em novembro.

17. Cyrtopodium flavum Link \& Otto ex Rchb. Iconogr. Bot. Exot. 3: 7, t. 214. 1830. Fig. 5a-i

Terrícola, 1-1,5 m compr.; crescimento simpodial, cespitoso. Caule tipo pseudobulbo ca. $46 \times 2,5 \mathrm{~cm}$, fusiforme, 6-7-foliado. Folhas com nervação paralela, na antese $26-33,5 \times 0,5-0,7$ $\mathrm{cm}$, dísticas, lanceoladas, verdes, membranáceas, ápice agudo. Inflorescência lateral, mais de 30 flores; pedúnculo 0,6-1 m compr.; brácteas do pedúnculo 4, 3-5,5 cm compr., lanceoladas; raque 32-43 cm compr.; brácteas florais 1,6-1,8 $\mathrm{cm}$ compr., lanceoladas. Flores monoclinas, ressupinadas, verde-amareladas; pedicelo com ovário ca. 2,5 cm compr.; sépalas eretas, ovadas, glabras, as laterais $1,2-1,6 \times 0,8-1 \mathrm{~cm}$, livres entre si, a mediana $1-1,6 \times$ ca. $1 \mathrm{~cm}$; pétalas $1-1,4 \times$ 0,8-1 cm, eretas, inteiras, ovadas; labelo trilobado, amarelo, membranáceo, glabro, margem inteira, com calosidade orbicular, carnosa, glabra, lobos laterais ca. $1 \times 0,5 \mathrm{~cm}$, arredondados, eretos, lobo mediano 6-8 $\times 1-1,2 \mathrm{~cm}$, cordiforme; coluna ca. 8 $\times$ 3-5 mm, livre; polínias 2, iguais, ovais.

Material examinado: Morro do Chapéu, Cachoeira do Ferro Doido, 10.XI.2001, fl., E.L. Borba 2071 (HUEFS).

Espécie endêmica do Brasil, ocorre da Paraíba ao Rio Grande do Sul, em Cerrado e Mata Atlântica, sendo encontrada na Bahia em áreas de restinga e na Chapada Diamantina nos municípios de Lençóis, Morro do Chapéu, Palmeiras e Mucugê, citada como C. polyphyllum (Vell.) Pabst ex F.Barros . Em Morro do Chapéu ocorre em caatinga e mata ciliar. Floresce em setembro.

Romero-González et al. (2008), a partir da análise das ilustrações e de materiais tipo, reconheceram que $C$. flavum é nome correto para $C$. polyphyllum e C. paranaensis Schltr. Cyrtopodium flavum é similar a C. andersonii (Lamb. ex Andrews) R.Br., mas C. flavum tem flores menores e sépalas mais largas que esta última espécie.

18. Cyrtopodium saintlegerianum Rchb. f., Flora 68: 301. 1885.

Fig. $5 \mathrm{j}-\mathrm{q}$

Epífita, ca. $1 \mathrm{~m}$ compr.; crescimento simpodial, cespitoso. Caule tipo pseudobulbo $58-72 \times 2,5-3 \mathrm{~cm}$, fusiforme, 8-10-foliado. Folhas com nervação paralela, 66-70 × 2,5-3,5 $\mathrm{cm}$, dísticas, lanceoladas, verdes, membranáceas, 

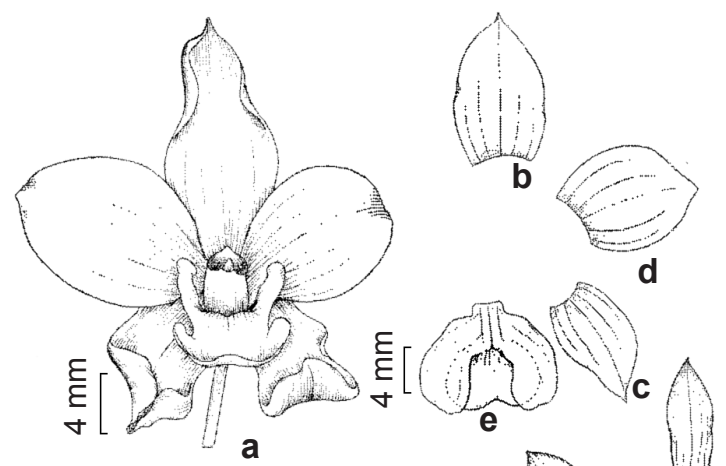

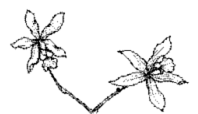

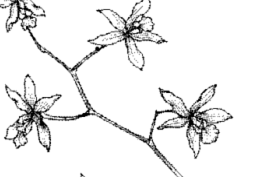

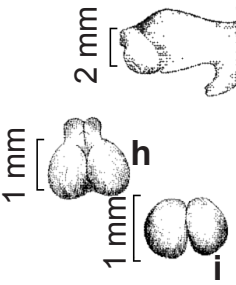

a

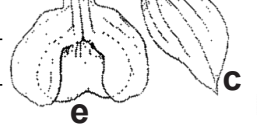<smiles>C1=CCCCCC1</smiles><smiles>C1[Al]C[As]1</smiles>

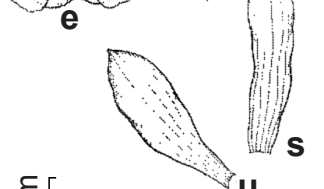

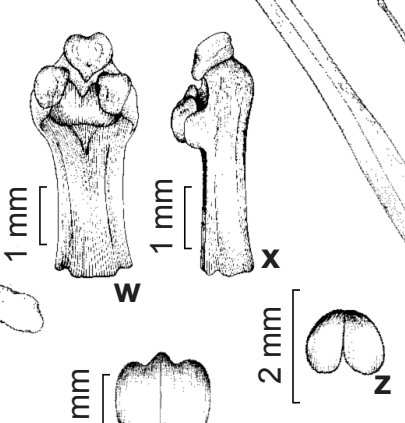

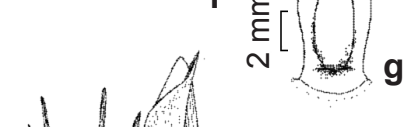<smiles>C#CC12CCC3CC(CC(C3)C1)C2</smiles>

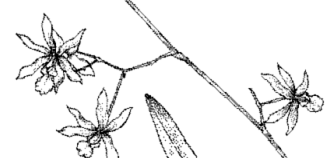<smiles>[AlH2][CH]CC[TeH]</smiles>
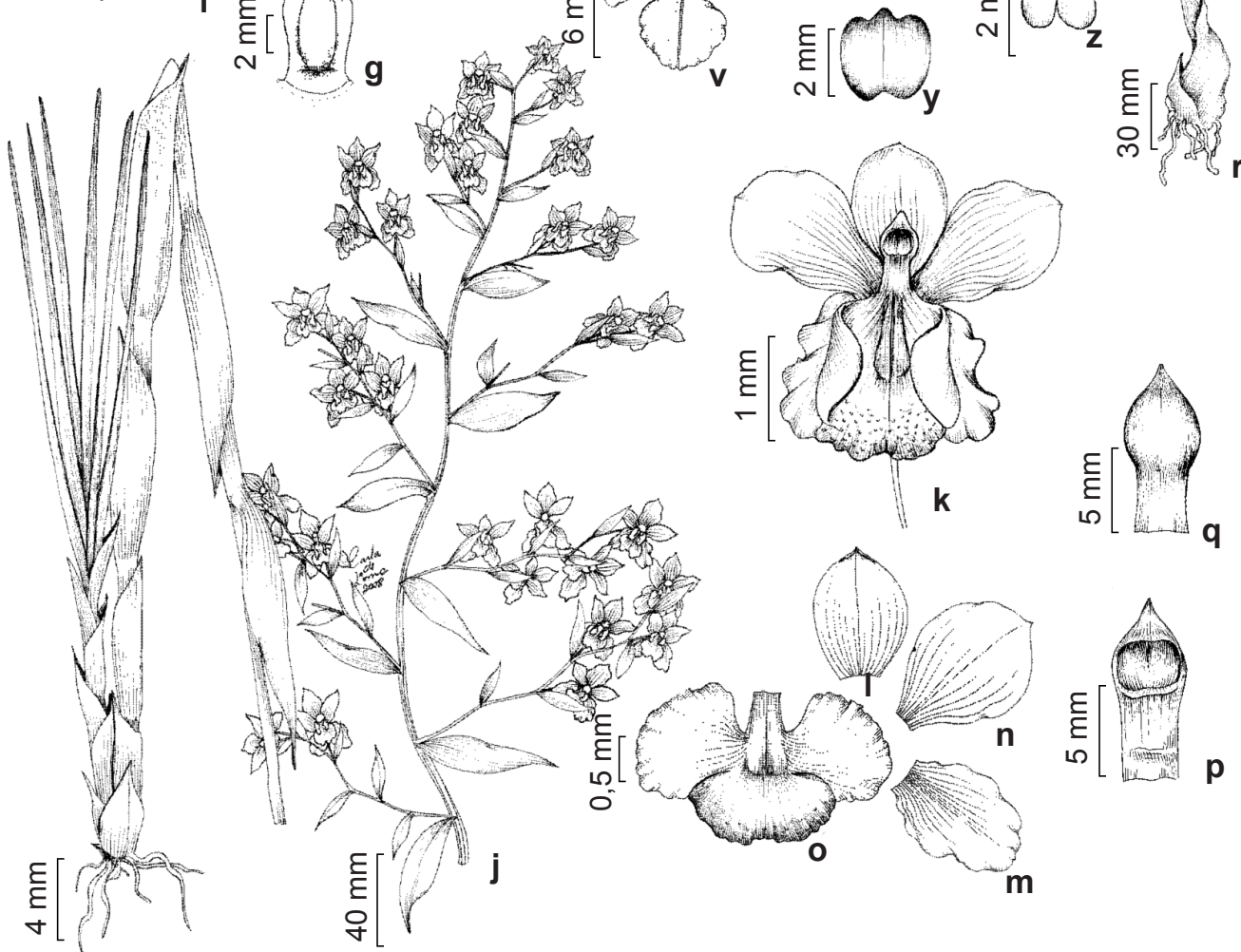

Figura 5 - a-i. Cyrtopodium flavum - a. flor; b. sépala dorsal; c. sépala lateral; d. pétala; e. labelo; f. ovário e coluna em vista lateral; g. coluna em vista ventral; h. antera em vista ventral; i. polínias. j-q. Cyrtopodium saintlegerianum - j. hábito; k. flor; 1. sépala dorsal; m. sépala lateral; n. pétala; o. labelo; p. coluna em vista ventral; q. coluna em vista dorsal. r-z. Encyclia patens -r. hábito; s. sépala dorsal; t. sépala lateral; u. pétala; v. labelo; w. porção do ovário e coluna em vista ventral; x. porção do ovário e coluna em vista lateral; y. antera em vista dorsal; z. polínias. (a-i Borba 2071; j Borba 1549; k-q Bastos 274; r-z Melo 5071). Figure 5 - a-i Cyrtopodium flavum - a. flower; b. dorsal sepal; c. lateral sepal; d. petal; e. lip; f. ovary and column in side view; g. column seen from beneath; h. anther seen from beneath; i. pollinia. j-q. Cyrtopodium saintlegerianum - j. habit; k. flower; 1. dorsal sepal; $m$. lateral sepal; n. petal; o. lip; p. column seen from beneath; q. column seen from above. r-z. Encyclia patens - r. habit; s. dorsal sepal; t. lateral sepal; u. petal; v. lip; w. part of ovary and column seen from beneath; x. part of ovary and column in side view; $y$. anther seen from above; $z$. pollinia. (a-i Borba 2071; j Borba 1549; k-q Bastos 274; r-z Melo 5071). 
ápice agudo. Inflorescência lateral, mais de 30 flores; pedúnculo 67-68 cm compr.; brácteas do pedúnculo 6-7, 11-14,7 cm compr., ovadas; raque 31-39 cm compr.; brácteas florais 2,4-3 $\mathrm{cm}$ compr., lanceoladas. Flores monoclinas, ressupinadas, amarelas com máculas vináceas; pedicelo com ovário 1-3,2 cm compr.; sépalas ovadas, eretas, glabras, as laterais ca. 1,3 $\times 1 \mathrm{~cm}$, livres entre si, a mediana 1,2-1,6 × 0,7-0,9 cm; pétalas $1-1,5 \times$ ca. $1 \mathrm{~cm}$, eretas, inteiras, ovadas; labelo trilobado, amarelo pintalgado de vermelho, carnoso, glabro, margem inteira, com calosidade orbicular, carnosa, glabra, lobos laterais $0,6-0,7$ $\times 0,6-1 \mathrm{~cm}$, auriculados, eretos, lobo mediano $0,9-1,3 \times 0,8-1,4 \mathrm{~cm}$, reniforme; coluna ca. $8 \times 4$ $\mathrm{mm}$, livre, antera 2,9-4 × 2,5-3 mm, com apêndice apical; polínias 2, iguais, ovais.

Material examinado: Morro do Chapéu, estrada para Jacobina, 13.XI.2008, fl., C.A. Bastos \& J.B. Pinto 274 (HUEFS).

Material adicional: BRASIL. BAHIA: Jacobina, estrada para Várzea Nova, 24.IX.2004, fl., E.L. Borba et al. 1949 (HUEFS).

Ocorre no Pará, Tocantins, Piauí, Bahia, Mato Grosso, Goiás, Distrito Federal, Mato Grosso do Sul e Minas Gerais, nos domínios fitogeográficos da Amazônia, Caatinga e Cerrado. $\mathrm{Na}$ Chapada Diamantina é provável sua ocorrência nos municípios de Abaíra, Palmeiras e Paramirim, sendo identificada como C. gigas (Vell.) Hoehne por Toscano de Brito \& Cribb (2005). Esses autores consideram o $C$. saintlegerianum como uma das várias formas de C. gigas. Essas espécies pertencem ao complexo taxonômico do Cyrtopodium puncatum (L.) Lindl. que é caracterizado pelo hábito epífito, pseudobulbos grandes, fusiformes e flores fechadas formando pequenas esferas. O complexo inclui ainda $C$. pflanzei Schltr., C. palmifrons Rchb.f. \& Warm. e C. schargellii G. A. Romero, Aymard \& Carnevali. Cyrtopodium punctatum é restrito ao Sul da Flórida e Antilhas, $C$. gigas é restrito ao Brasil em Mata Atlântica, enquanto C. saintlegerianum ocorre no Brasil e Paraguay (Romero-González 2008; Barros et al. 2010). Para Hoehne (1942), C. gigas, C. punctatum Lindl. e C. saintlegerianum são bastante distintos entre si no interior do Brasil, consideração refletida também por Menezes (2000) que trata essas espécies separadamente. No município de Morro do Chapéu foi coletada formando uma grande touceira sobre palmeira, Syagrus coronata, em área de caatinga, exposta ao sol. Floresce em novembro.
19. Encyclia alboxanthina Fowlie, Orchid Digest 54: 27. 1990.

Rupícola, 0,7-1,3 m compr.; crescimento simpodial, cespitoso. Caule tipo pseudobulbo 7,5-12 × 1,5-2,5 cm, cônico, 3-foliado. Folhas com nervação paralela, 17,5-29 × 1,5-3 cm, espiraladas, oblongas, verdes, coriáceo-carnosas, ápice obtuso a agudo. Inflorescência apical, 6-20 flores; pedúnculo 51,5-73,5 cm compr.; brácteas do pedúnculo 6-8, 0,9-1,5 cm compr., lanceoladas; raque $28,5-52 \mathrm{~cm}$ compr.; brácteas florais $3-4 \mathrm{~mm}$ compr., ovadas. Flores monoclinas, ressupinadas, predominantemente verdes; pedicelo com ovário 2,7-3,2 cm compr.; sépalas patentes oblongas, glabras, as laterais $1,7-2,2 \times 0,7-1 \mathrm{~cm}$, livres entre si, a mediana $1,8-2,4 \times 0,7-1 \mathrm{~cm}$; pétalas $1,6-2 \times 0,5-1 \mathrm{~cm}$, patentes, inteiras, espatuladas; labelo trilobado, branco, suavemente tracejado de vináceo, membranáceo, glabro, margem inteira, com calosidade carnosa, cimbiforme, glabra, lobos laterais ca. $1 \times 0,4-0,6 \mathrm{~cm}$, cuneiformes, envolvendo a coluna, lobo mediano ca. $1 \times 1,2 \mathrm{~cm}$, orbicular; coluna ca. $1 \times 0,4 \mathrm{~cm}$, livre, com projeções laterais, próximas ao ápice, em forma de ganchos; antera 2-3,1 × 3-4 mm, sem apêndice apical; polínias 4, iguais, elípticas.

Materiais examinados: Morro do Chapéu, Estrada do Feijão, 28.XI.1980, fl., A. Furlan et al. 276 (K, SP); Morrão, 17.XI.2008, fl., C.A. Bastos \& J. B. Pinto 252 (HUEFS); Tabuleiro dos Tigres, 4.I.2005, fl., J.G.A. Nascimento 201 (HUEFS); Ventura, 17.XII.2005, fl., F. França 5377 (HUEFS).

Endêmica da Bahia, provavelmente da Chapada Diamantina, ocorre em Caatinga e Cerrado. É comum nos municípios de Abaíra, Andaraí, Barra da Estiva, Jacobina, Lençóis, Morro do Chapéu, Mucugê e Palmeiras. Em Morro do Chapéu foi encontrada em campo rupestre, sobre afloreamentos rochosos. Floresce de outubro a janeiro.

Encyclia alboxanthina é similar a E. osmantha Barb.Rodr., mas diferencia-se desta pela margem inteira das sépalas e pétalas, pelo lobo mediano do labelo que é orbicular e o lobo lateral cuneiforme, enquanto $E$. osmantha possui sépalas e pétalas de margem ondulada, lobo mediano do labelo subquadrado e lobos laterais ligulados (Castro Neto \& Campacci 2006).

20. Encyclia kundegraberi V.P.Castro \& Campacci, Orquidário 1: 7.1998.

Epífita, 43-48 cm compr.; crescimento simpodial, subcespitoso. Caule tipo pseudobulbo 3,5-4,5 × 1-3 cm, ovado, 2-foliado. Folhas com 
nervação paralela, $22-23 \times 0,6-0,7 \mathrm{~cm}$, dísticas, oblongas, verdes na face adaxial e vináceas na abaxial, coriáceo-carnosas, ápice agudo. Inflorescência apical, 2-7 flores; pedúnculo 26-30 cm compr.; brácteas do pedúnculo 5, 6-7 mm compr., oblongas; raque 11,5-14 cm compr.; brácteas florais $2-3 \mathrm{~mm}$ compr., lanceoladas. Flores monoclinas, ressupinadas, predominantemente esverdeadas; pedicelo com ovário 1,5-2,2 cm compr.; sépalas eretas, oblongas, glabras, as laterais $1,2-1,5 \times 0,3-0,5 \mathrm{~cm}$, livres entre si, a mediana $1-1,4 \times 0,3-0,5 \mathrm{~cm}$; pétalas $1,2-1,3 \times$ $0,3-0,4 \mathrm{~cm}$, eretas, inteiras, lanceoladas; labelo trilobado, branco com mácula rósea, membranáceo, glabro, margem inteira, com calosidade carnosa, cimbiforme, glabra, lobos laterais $7-9 \times 2-3 \mathrm{~mm}$, ovados, envolvendo a coluna, lobo mediano $0,8-1,3$ $\times 0,4-0,7 \mathrm{~cm}$, orbicular; coluna $6-8 \times 2-5 \mathrm{~mm}$, livre, com projeções laterais, próximas ao ápice, em forma de ganchos; antera $2,1 \times 2,2 \mathrm{~mm}$, sem apêndice apical; polínias 4, iguais, elípticas.

Materiais examinados: Morro do Chapéu, estrada para Buraco do Possidônio, 18.XII.2008, fl., C.A. Bastos \& C. van den Berg 176 (HUEFS); sem local, 10.XII.1997, fl., H. Kundegraber (Holótipo: SP 333602).

Endêmica do Brasil, há registro para a Bahia e Minas Gerais em áreas de Caatinga. Ocorre em Palmeiras, Chapada Diamantina, sendo também coletada no sudoeste baiano, em Vitória da Conquista (Toscano de Brito \& Cribb 2005). Esta espécie foi descrita a partir de material coletado em Morro do Chapéu, onde é encontrada em área de transição entre caatinga e cerrado sobre tronco de árvores. Floresce em dezembro.

Encyclia kundegraberi é similar a E. seidelii Pabst, mas diferencia-se desta pelos numerosos rizomas curtos, pseudobulbos mais arredondados, hábito epífita, folhas compridas e estreitas e lobo mediano do labelo menor que os laterais, enquanto E. seidelii apresenta rizomas compridos, bulbos fusiformes mais alongados, é sempre rupícola, possui folhas curtas, largas e mais carnosas, e os lobos laterais do labelo são menores que o lobo mediano.

\section{Encyclia oncidioides (Lindl.) Schltr., Orchideen} 210. 1914.

Epífita ou rupícola, ca. 1,3 m compr.; crescimento simpodial, cespitoso. Caule tipo pseudobulbo ca. $8 \times$ 2,5 cm, cônico, 2-foliado. Folhas com nervação paralela, ca. $47 \times 3 \mathrm{~cm}$, dísticas, oblongas, verdes, carnosas, ápice agudo. Inflorescência apical, ca. 6 flores; pedúnculo ca. $68 \mathrm{~cm}$ compr.; brácteas do pedúnculo 8 , ca. $8 \mathrm{~mm}$ compr., lanceoladas; raque ca. $24 \mathrm{~cm}$ compr.; brácteas forais $1-3 \mathrm{~mm}$ compr., ovadas. Flores monoclinas, ressupinadas, predominantemente amarelas com máculas vináceas; pedicelo com ovário ca. 1,8 cm compr.; sépalas eretas, levemente involutas, oblongas a lanceoladas, glabras, as laterais ca. 1,7 $\times$ $0,5 \mathrm{~cm}$, livres entre si, a mediana ca. $1,7 \times 0,5 \mathrm{~cm}$; pétalas ca. $1,7 \times 0,7 \mathrm{~cm}$, eretas, levemente involutas, inteiras, ovadas; labelo trilobado, branco, fortemente tracejado de vináceo, membranáceo, glabro, margem inteira, com calosidade carnosa, cimbiforme, glabra, lobos laterais ca. $9 \times 3 \mathrm{~mm}$, retangulares, envolvendo a coluna, lobo mediano $0,8-1 \times$ ca. $0,8 \mathrm{~cm}$, cordiforme; coluna ca. $1 \times 0,3 \mathrm{~cm}$, livre, com projeções laterais, próximas ao ápice, em forma de ganchos; antera 2,1 $\times 2,5 \mathrm{~mm}$, sem apêndice apical; polínias 4 , iguais, elípticas.

Material examinado: Morro do Chapéu, Fazenda Angico, 14.XII.2003, fl., C. van den Berg 1059 (HUEFS). Material adicional: BRASIL, BAHIA: Jacobina, 17.XI.2007, fl., L.P. Queiroz 12994 (HUEFS).

Ocorre do norte ao sul do Brasil nos mais variado tipos vegetacionais. $\mathrm{Na}$ Chapada Diamantina foi citada para os municípios de Abaíra, Palmeiras e Rio de Contas. No município de Morro do Chapéu foi coletada em área de caatinga sobre tronco de árvores e em afloramentos rochosos. Com flor em dezembro.

22. Encyclia patens Hook., Bot. Mag. 57: t. 3013. 1830.

Fig. 5r-z

Epífita, ca. $38 \mathrm{~cm}$ compr.; crescimento simpodial, cespitoso. Caule tipo pseudobulbo ca. 4 $\times 1,7-2 \mathrm{~cm}$, cônico, 2-foliado. Folhas com nervação paralela, $19-24 \times$ ca. $1 \mathrm{~cm}$, dísticas, oblongas, verdes, carnosas, ápice agudo. Inflorescência apical, ca. 10 flores; pedúnculo 15,5-18 cm compr.; brácteas do pedúnculo 5, 4-6 mm compr., lanceoladas; raque 17-19 cm compr.; brácteas florais ca. $3 \mathrm{~mm}$ compr., ovadas. Flores monoclinas, ressupinadas, amarelo- acastanhadas; pedicelo com ovário ca. $2 \mathrm{~cm}$ compr.; sépalas eretas, oblongas, glabras, as laterais ca. $1,4 \times 0,4 \mathrm{~cm}$, livres entre si, a mediana ca. $1,5 \times 0,4 \mathrm{~cm}$; pétalas $1,3-1,6 \times$ ca. $0,6 \mathrm{~cm}$, eretas, inteiras, ovadas; labelo trilobado, amarelado, membranáceo, glabro, margem inteira, com calosidade carnosa longitudinal com fenda linear no centro, glabra, lobos laterais 5-8 $\times 2-4 \mathrm{~mm}$, retangulares, envolvendo a coluna, lobo mediano ca. $8 \times 7-9 \mathrm{~mm}$, elíptico; coluna $7-8 \times$ ca. $3 \mathrm{~mm}$, livre, com projeções laterais, próximas ao ápice, em forma de ganchos; antera 1-1,5 × 1-1,1 mm, sem apêndice apical; polínias 2, iguais, ovais. 
Materiais examinados: Morro do Chapéu, Morrão, 8.IX.2007, fl., E. Melo 5071 (HUEFS).

Endêmica do Brasil, há registros para Pernambuco, Bahia, Minas Gerais, Espírito Santo, São Paulo, Rio de Janeiro, Paraná, Santa Catarina e Rio Grande do Sul, em áreas de Cerrado e Mata Atlântica. Na Chapada Diamantina ocorre nos municípios de Mucugê, Palmeiras e Rio de Contas. Em Morro do Chapéu foi coletada em área de mata de grotão sobre tronco de árvores. Floresce em setembro.

Encyclia patens é similar a $E$. oncidioides mas diferenciam-se pelo período de floração e pelo porte da planta que é menor. Em E. patens, as flores são menores em relação a $E$. oncidioides e a inflorescência tem ca. $35 \mathrm{~cm}$ de compr., enquanto E. oncidioides apresenta inflorescências bem maiores com ca. $90 \mathrm{~cm}$ de compr. (Castro Neto \& Campacci 2006).

23. Epidendrum cinnabarinum Salzm. ex Lindl., Bot. Mus. Leafl. 106. 1831.

Fig. 6a-h

Epífita, 32-91,5 cm compr.; crescimento simpodial; subcespitoso. Caule tipo cauloma 11-39 × 0,4-0,6 cm, cilíndrico, 3-8-foliado. Folhas com nervação paralela, 6-10 × 1-2 cm, dísticas, ovadas, verdes, carnosas, ápice agudo. Inflorescência apical, com keiki, 2-4 flores; pedúnculo 9-48 cm compr.; brácteas do pedúnculo 4-7, 1-2 cm compr., oblongas; raque 2,5-9,5 cm compr.; brácteas florais $0,5-1 \mathrm{~cm}$ compr., lanceoladas. Flores monoclinas, não ressupinadas, alaranjadas a avermelhadas; pedicelo com ovário 2,2-3,5 cm compr.; sépalas eretas, oblongas, glabras, as laterais $1,7-2,6 \times 0,5-0,6 \mathrm{~cm}$, livres entre si, a mediana $1,6-2,5 \times 0,5-0,6 \mathrm{~cm}$; pétalas $1,6-2,6 \times 0,5-0,6$ $\mathrm{cm}$, eretas, inteiras, lanceoladas; labelo trilobado, alaranjado a avermelhado, membranáceo, glabro, com 2 calos lineares, eretos, glabros, lobos laterais 0,6-0,7 × 0,6-1 cm, flabeliformes, explanados, margem fimbriada, lobo mediano $6-7 \times$ ca. $4 \mathrm{~mm}$, triangular, margem inteira; coluna 1,4-1,8 × 0,4$0,5 \mathrm{~cm}$, totalmente adnata abaxialmente ao labelo. Materiais examinados: Morro do Chapéu, próximo ao sítio Novo Horizonte, 17.IX.2008, fl., C.A. Bastos \& J.B. Pinto 187 (HUEFS); Fazenda Guariba, 4.V.2007, fl., F. França at al. 5661 (HUEFS); 1.VII.2007, fl., fr., E. Melo et al. 4962 (HUEFS).

Essa espécie ocorre nos estados do Pará, Amazonas, Rio Grande do Norte, Pernambuco, Bahia, Alagoas, Sergipe e Mato Grosso, em Mata Atlântica. Na Bahia é citada para áreas de restinga e para a Chapada Diamantina, embora os municípios de ocorrência sejam incertos. No município de Morro do Chapéu, foi coletado em caatinga, sobre tronco de árvores. Vegetativamente é muito similar ao E. secundum Jacq., mas suas flores são vermelhas e maiores, com labelo densamente fimbriado. Floresce de maio a setembro.

24. Epidendrum cristatum Ruiz \& Pav., Syst. Veg. Fl. Peruv. Chil.1: 243. $1798 . \quad$ Fig. 6i-1

Terrícola, 2-3 m compr.; crescimento simpodial, cespitoso. Caule tipo cauloma 1,7-3 m $\times 1-2 \mathrm{~cm}$, cilíndrico, com mais de 36 folhas. Folhas com nervação paralela, 14-17 × 2-4,5 cm, dísticas, oblongas, verdes, coriáceo-carnosas, ápice obtuso. Inflorescência apical, geralmente com keiki, com mais de 30 flores; pedúnculo 10-26 cm compr.; brácteas do pedúnculo 4-9, 7,5-1 cm compr., lanceoladas; raque 12,5-26,5 cm compr.; brácteas florais 4-8 $\mathrm{mm}$ compr., lanceoladas. Flores monoclinas, ressupinadas, amareladas com máculas vináceas; pedicelo com ovário 3-3,6 cm compr.; sépalas eretas, oblongas, glabras, as laterais 6-7 × 7-8 mm, livres entre si, a mediana $1,7-2 \times 0,5-0,6 \mathrm{~cm}$; pétalas 1,6-1,8 $\times$ ca. $0,6 \mathrm{~cm}$, eretas, inteiras, obovadas; labelo trilobado, esbranquiçado com mácula magenta, membranáceo, glabro, margem dividida, lobos laterais 6-7 × 7-8 mm, flabeliformes, explanados, lobo mediano ca. $8 \times 6-8 \mathrm{~mm}$, sagitado; coluna $1,2-1,4 \times 0,5-0,8 \mathrm{~cm}$, totalmente adnata abaxialmente ao labelo; antera $2 \times 2 \mathrm{~mm}$, sem apêndice apical.

Material examinado: Morro do Chapéu, Fazenda Guariba, 8.IV.2008, veg., C. A. Bastos \& C. van den Berg 186(HUEFS). Materiais adicionais: BRASIL. BAHIA: Mucugê, Parque Municipal de Mucugê, 20.IX.2002, fl., C. Azevedo 156 (HUEFS); Piatã, caminho Guarda Morfrios, 22.X.1992, fl., W. Ganev 1301 (HUEFS).

Ocorre na Bahia, Minas Gerais, Espírito Santo, São Paulo, Rio de Janeiro, Paraná, Santa Catarina e Rio Grande do Sul, em vegetação de Caatinga, Cerrado e Mata Atlântica. Na Bahia já foi registrada para os municípios de Abaíra, Ibicoara, Mucugê, Palmeiras e Piatã, além de material de Santa Terezinha depositado em herbário. No município de Morro do Chapéu, essa espécie foi coletada em área de floresta, com flor em abril.

25. Epidendrum orchidiflorum Salzm. ex Lindl., Gen. Sp. Orchid. P1. 103. 1853.

Rupícola, 0,4-1,3 m compr., crecimento simpodial, cespitoso. Caule tipo cauloma 21-38 $\times$ 0,3-0,5 cm, cilíndrico, 14-36-foliado. Folhas com nervação paralela, 3,5-5 × 1-1,5 cm, dísticas, ovadas a lenceoladas, verdes, coriáceo-carnosas, ápice 


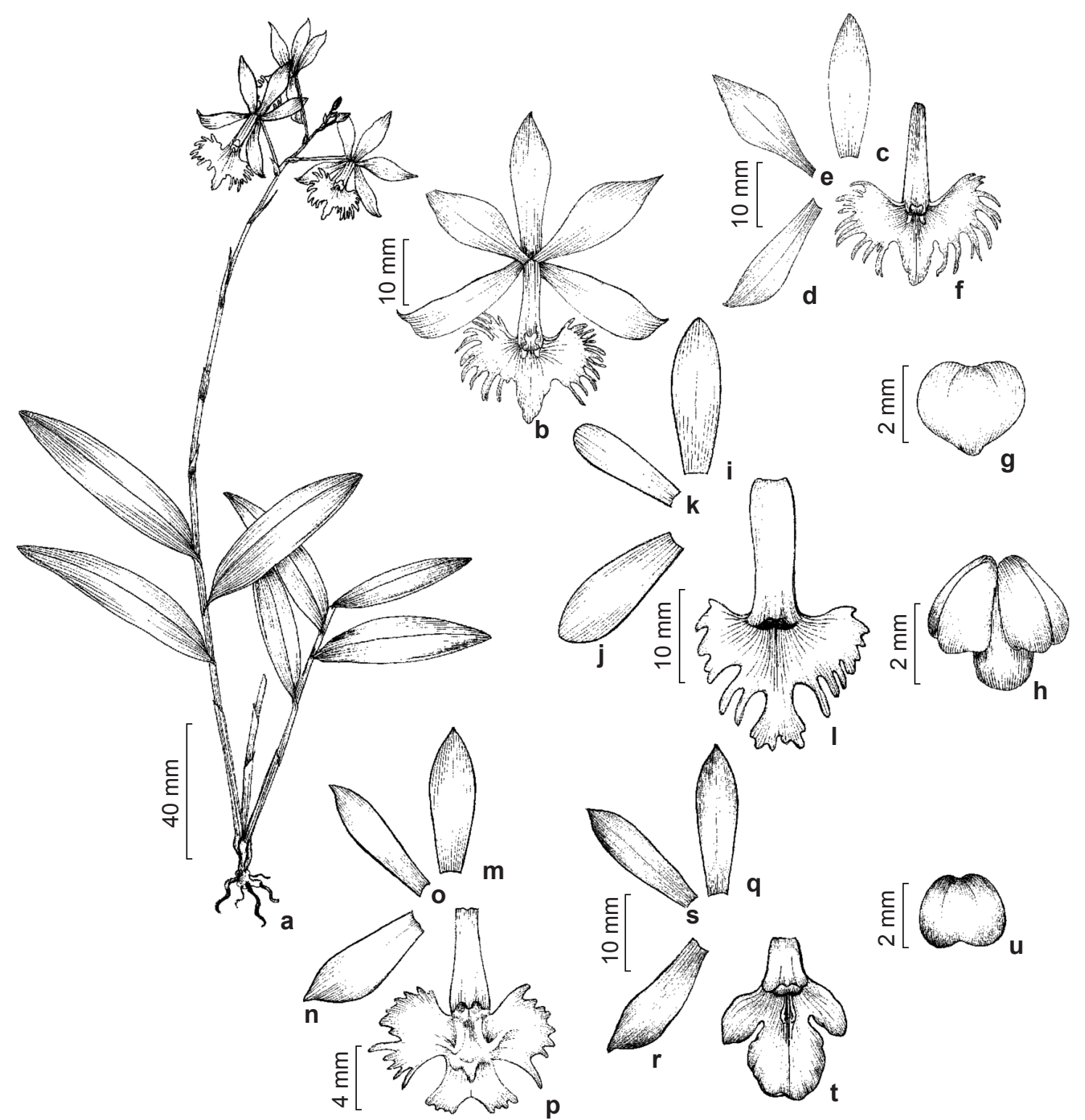

Figura 6 - a-h. Epidendrum cinnabarinum - a. hábito; b. flor; c. sépala dorsal; d. sépala lateral; e. pétala; f. labelo; g. antera em vista dorsal; h. polinário. i-1. Epidendrum cristatum - i. sépala dorsal; j. sépala lateral; k. pétala; 1. labelo. m-p. Epidendrum secundum - m. sépala dorsal; $n$. sépala lateral; o. pétala; p. labelo. q-u. Epidendrum warasii-q. sépala dorsal; r. sépala lateral; s. pétala; t. labelo; u. antera em vista dorsal. (a Melo 4962, b-h Bastos 187; i-1 Azevedo 156; m-p Bastos 118; q-u Pereira 91). Figure 6 - a-h. Epidendrum cinnabarinum - a. habit; b. flower; c. dorsal sepal; d. lateral sepal; e. petal; f. lip; g. anther seen from above; h. pollinarium. i-l. Epidendrum cristatum - i. dorsal sepal; j. lateral sepal; k. petal; l. lip. m-p. Epidendrum secundum - m. dorsal sepal; $\mathrm{n}$. lateral sepal; o. petal; p. lip. q-u. Epidendrum warasii-q. dorsal sepal; r. lateral sepal; s. petal; t. lip; u anther seen from above. (a Melo 4962, b-h Bastos 187; i-1 Azevedo 156; m-p Bastos 118; q-u Pereira 91).

agudo. Inflorescência apical, geralmente com keiki, 5-9 flores; pedúnculo 11-85 cm compr.; brácteas do pedúnculo 7-26, 2-3,8 cm compr., oblongas; raque 2,5-6 cm compr.; brácteas florais $4-8 \mathrm{~mm}$ compr., lanceoladas. Flores monoclinas, ressupinadas, amareladas com máculas castanhas; pedicelo com ovário ca. $1,7 \mathrm{~cm}$ compr.; sépalas eretas, ovadas, glabras, as laterais $0,8-1 \times$ ca. $0,5 \mathrm{~cm}$, livres entre si, a mediana $0,9-1 \times 0,4-0,5 \mathrm{~cm}$; pétalas $0,7-1 \times \mathrm{ca}$. $0,1 \mathrm{~cm}$, eretas, inteiras, lanceoladas; labelo inteiro, ca. $1,4 \times 1,5 \mathrm{~cm}$, reniforme, amarelado, pintalgado de castanho, carnoso, glabro, margem inteira, com 
2 calos carnosos, circulares, glabros; coluna 4,5-6,5 $\times 2-3,5 \mathrm{~mm}$, totalmente adnata abaxialmente ao labelo, com projeções laterais, ventro-apicais, ovadas; antera 0,9-1,5 × 0,9-1,7 mm, sem apêndice apical; polínias 4 , iguais, elípticas.

Materiais examinados: Morro do Chapéu, BA 052, 19.XI.1986, fl., L.P. Queiroz 1287 (HUEFS); Cachoeira do Ferro Doido, 4.I.2005, fl., J.G.A. Nascimento 195 (HUEFS); estrada de chão à direita no caminho do Morrão, 18.XII.2008, fl., C.A. Bastos \& C. van den Berg 162 (HUEFS); estrada para Bonito, 19.IV.2001, f1., E. Melo 3289 (HUEFS); Morrão, 17.XII.2005, fl., F. França 5370 (HUEFS).

Ocorre em Roraima, Pará, Amazonas, Bahia, Alagoas, Sergipe e Rio de Janeiro, nos domínios fitogeográficos daAmazônia, Caatinga, Cerrado e Mata Atlântica. Na Chapada Diamantina é comum desde Rio de Contas até Jacobina, com ocorrência registrada em Lençóis, Mucugê e Palmeiras. No município de Morro do Chapéu ocorre nos campos rupestres, sobre afloramentos rochosos. Floresce praticamente todo o ano, principalmente de outubro a abril.

26. Epidendrum secundum Jacq., Enum. Syst. Pl. 29. 1760.

Fig. $6 \mathrm{~m}-\mathrm{p}$

Rupícola ou terrícola, $0,2-1,8 \mathrm{~m}$ compr.; crescimento simpodial, cespitoso. Caule tipo cauloma 6-87 × 0,5-1 cm, cilíndrico, 4-21-foliado. Folhas com nervação paralela, $3-10 \times 0,5-3 \mathrm{~cm}$, dísticas, ovadas, verdes, carnosas, ápice agudo. Inflorescência apical, geralmente com keiki, 5-20 flores; pedúnculo 17-81 cm compr.; brácteas do pedúnculo 3, 1,5-4,8 cm compr., oblongas; raque 4-11,5 cm compr.; brácteas florais $2-9 \mathrm{~mm}$ compr., lanceoladas. Flores monoclinas, não ressupinadas, lilases; pedicelo com ovário 1,4-2,2 cm compr.; sépalas eretas, lanceoladas, glabras, as laterais $7-9 \times 2,5-3,5 \mathrm{~mm}$, livres entre si, a mediana $6,5-8 \times 2,5-3 \mathrm{~mm}$; pétalas $7-8,5 \times 1,5-3 \mathrm{~mm}$, eretas, inteiras, oblongas; labelo trilobado, lilás, membranáceo, glabro, margem denticulada a fimbriada, com 2 calos obcordados e 1 hastado, glabro, lobos laterais 2-3× ca. $3 \mathrm{~mm}$, flabeliformes, explanados, lobo mediano ca. $2 \times 4 \mathrm{~mm}$, sagitado; coluna 4,5-8 $\times 1-3 \mathrm{~mm}$, totalmente adnata abaxialmente ao labelo, com projeções laterais, ventro-apicais, falcadas; antera 1,5-4 × 1-2,7 mm, com apêndice apical; polínias 4 , iguais, elípticas. Materiais examinados: Morro do Chapéu, Cachoeira do Ferro Doido, 10.X.2007, fl., C.A. Bastos 117, 118 (HUEFS); Morrão, 13.XI.2008, f1., C.A. Bastos \& J.B. Pinto 273 (HUEFS); Tabuleiro dos Tigres, 19.III.2004, fl., D.T. Cruz 6 (HUEFS).
Trata-se de uma espécie de ampla distribuição (Pabst \& Dungs 1975), com ocorrência de norte a sul do Brasil, sendo encontrada nos mais variados tipos vegetacionais. Na Chapada Diamantina ocorre desde Jacobina, ao norte, até Rio de Contas, ao sul. Em Morro do Chapéu, é comum sobre afloramentos rochosos de campo rupestre ou mata ciliar. Ocorre também em caatinga, exposta ao sol ou sob a sombra dos arbustos. Floresce de outubro a maio.

27. Epidendrum warasii Pabst, Orchid Rev. 79: 306.1971.

Fig. $6 \mathrm{q}-\mathrm{u}$

Rupícola, ca. 2,4 m compr.; crescimento simpodial, cespitoso. Caule tipo cauloma ca. 72 $\times 1,5 \mathrm{~cm}$, cilíndrico, 6-16-foliado. Folhas com nervação paralela, $8-10 \times 1-1,5 \mathrm{~cm}$, dísticas, oblongas, arroxeadas, crasso-carnosas, ápice agudo. Inflorescência apical, geralmente com keiki, 7-20 flores; pedúnculo 0,1-1,6 m compr.; brácteas do pedúnculo 5-42, 4-7 cm compr., lanceoladas; raque 4-11 cm compr.; brácteas florais 7-9 mm compr., lanceoladas. Flores monoclinas, ressupinadas, esverdeadas na face adaxial e vináceas na abaxial; pedicelo com ovário ca. 2,6 cm compr.; sépalas eretas, oblongas a lanceoladas, glabras, as laterais $1,2-2 \times 0,5-0,8 \mathrm{~cm}$, livres entre si, a mediana $1,2-1,7 \times$ ca. $0,5 \mathrm{~cm}$; pétalas $1,2-1,9$ $\times 0,3-0,5 \mathrm{~cm}$, eretas, inteiras, oblongas; labelo trilobado, creme, carnoso, glabro, margem inteira, com 2 calos carnosos orbiculares e 1 linear longitudinal, glabros, lobos laterais 5,5-7 × 3,5-4 mm, oblongos, explanados, lobo mediano $0,6-1 \times 0,6-0,7 \mathrm{~cm}$, orbicular; coluna 6-9 6 4-6 mm, totalmente adnata abaxialmente ao labelo; antera $17-24 \times 22-30 \mathrm{~mm}$, sem apêndice apical; polínias 4, iguais, elípticas. Materiais examinados: Morro do Chapéu, Cachoeira do Ferro Doido, 10.XI.2001, fl., E.L. Borba 2073 (HUEFS); estrada para Bonito, 4.III.2008, f1., C.A. Bastos 121 (HUEFS); Tabuleiro dos Tigres, 18.III.2004, fl., D.T. Cruz 3 (HUEFS); 22.IV.2004, fl., A. C. Pereira et al. 91 (HUEFS).

Endêmica do Brasil, e provavelmente da Cadeia do Espinhaço, ocorre em Minas Gerais e Bahia, em Caatinga e Cerrado. Na Bahia foi encontrada na Chapada Diamantina em Catolés e nos municípios de Mucugê, Morro do Chapéu, Palmeiras, Piatã e Rio de Contas. Em Morro do Chapéu é encontrada em campo rupestre, sobre afloramentos rochosos. Floresce de novembro a abril.

28. Epistephium lucidum Cogn., Fl. bras. 3 (4): 141, t. 30. 1893.

Terrícola, 0,8-1,3 m compr.; crescimento simpodial, cespitoso. Caule tipo cauloma 58-93 
$\times$ ca. $0,5 \mathrm{~cm}$, cilíndrico, ca. 6-foliado. Folhas com nervação reticulada, $12-16,5 \times 4-7 \mathrm{~cm}$, dísticas, ovadas, verdes, cartáceas, ápice agudo. Inflorescência apical, 15-22 flores; pedúnculo inconspícuo; raque 25-32,5 cm compr.; brácteas florais $0,7-1 \mathrm{~cm}$ compr., lanceoladas. Flores monoclinas, ressupinadas, róseas; pedicelo com ovário 2,4-3,7 cm compr.; epicálice presente; sépalas eretas, lanceoladas, glabras, as laterais 2,8 $4,3 \times 0,7-0,8 \mathrm{~cm}$, livres entre si, a mediana $3-4,4 \times$ $0,6-1 \mathrm{~cm}$; pétalas 2,6-4×0,8-1 cm, eretas, inteiras, lanceoladas; labelo inteiro, 2,3-3,7 × 0,7-1,2 cm, cordado, róseo, carnoso, piloso, margem inteira a ondulada. Coluna ca. $30 \times 5 \mathrm{~mm}$, livre.

Materiais examinados: Morro do Chapéu, Cachoeira do Ferro Doido, 17.I.1977, fl., G. Hatschbach 39706 (MBM); Serra da Boa Esperança, 11.III.2002, fl., W.W. Thomas et al. 12898 (CEPEC, HUEFS); Tabuleiro dos Tigres, 4.I.2005, fl., J.G.A. Nascimento 187 (HUEFS).

Endêmica do Brasil, ocorre em Roraima, Tocantins, Bahia, Goiás, Distrito Federal, Minas Gerais, Espírito Santo, São Paulo e Rio de Janeiro, nos domínios fitogeográficos da Amazônia, Caatinga, Cerrado e Mata Atlântica. Na Chapada Diamantina, ocorre em Catolés, Lençóis, Mucugê, Palmeiras e Rio de Contas. É citada por Toscano de Brito \& Cribb (2005) como Epistephium sclerophyllum Lindl., mas aparentemente apenas estes autores consideram E. lucidum um sinômimo da primeira. Barros et al. (2010) listaram estas duas espécies, como distintas, o que concorda com as diferenças na morfologia do labelo. As duas espécies crescem ainda sobre substratos distintos, sendo E. sclerophyllum exclusivamente em solos vermelhos de cerrado enquanto $E$. lucidum ocorre sempre em areia associada a afloramentos rochosos de campos rupestres e ainda em dunas litorâneas na Bahia e Espírito Santo.

29. Galeandra beyrichii Rchb.f., Linnaea 22: 854. 1850.

Fig. 7a-h

Terrícola, 31-83,5 cm compr.; crescimento simpodial, cespitoso. Caule tipo pseudobulbo ca. $1,7 \times 0,7 \mathrm{~cm}$, ovado, áfilo durante o período de floração. Folhas não vistas na fase reprodutiva. Inflorescência lateral, 1-3 flores; pedúnculo 26,5$70 \mathrm{~cm}$ compr.; brácteas do pedúnculo 9 , ca. 3,8 cm compr., lanceoladas; raque 4,5-13 cm compr.; brácteas florais $7-8 \mathrm{~mm}$ compr., lanceoladas. Flores monoclinas, ressupinadas, levemente esverdeadas; pedicelo com ovário 1,8-2,5 cm compr.; sépalas eretas, lanceoladas, glabras, as laterais $2,4-2,7$ $\times$ ca. $0,5 \mathrm{~cm}$, livres entre si, a mediana ca. $2,5 \times$ $0,5-0,6 \mathrm{~cm}$; pétalas $2,3-2,6 \times$ ca. $0,7 \mathrm{~cm}$, eretas, inteiras, lanceoladas; labelo inteiro, 1,8-2,5 × ca. 1,2 cm, campanulado, branco com listras vináceas, membranáceo, pilosa, margem inteira, tetracarenado; cálcar 5-8 mm compr., cônico; coluna ca. $8 \times 3-5 \mathrm{~mm}$, livre; antera $2,5 \times 2 \mathrm{~mm}$, com apêndice apical.

Materiais examinados: Morro do Chapéu, BA 052, 17.VI.2008, f1., C.A. Bastos 226 (HUEFS); Fazenda Guariba, 30.VI.2007, fl., fr., E. Melo et al. 4848 (HUEFS).

Ocorre na Bahia, Mato Grosso, Goiás, Distrito Federal, Minas Gerais, Espírito Santo, São Paulo, Rio de Janeiro, Paraná, Santa Catarina e Rio Grande do Sul, em Cerrado e Mata Atlântica. Na Bahia é encontrada em Itaberaba e Rui Barbosa, sem registro, até então, para a Chapada Diamantina. No município de Morro do Chapéu, é encontrada em áreas de floresta úmida, com flor em junho.

30. Gomesa barbata (Lind1.) M.W.Chase \& N.H.Williams, Ann. Bot. (Oxford) 104 (3): 395. 2009.

Fig. 7i-p

Epífita, 19,5-30 cm compr.; crescimento simpodial, subcespitoso. Caule tipo pseudobulbo 1,6-3,2 × 1-1,3 cm, ovado, 3-foliado. Folhas com nervação paralela, $6-8,5 \times 1-1,5 \mathrm{~cm}$, dísticas, oblongas, verdes, cartáceas, ápice agudo. Inflorescência lateral, 2-6 flores; pedúnculo 11-22 cm compr.; brácteas do pedúnculo $3-5,3-4 \mathrm{~mm}$ compr., oblongas; raque 3,5-12 cm compr.; brácteas florais $2-3,5 \mathrm{~mm}$ compr., ovadas. Flores monoclinas, ressupinadas, predominantemente amarelas com máculas marrons; pedicelo com ovário 1,3-2 cm compr.; sépalas reflexas, espatuladas, glabras, as laterais ca. $1 \times 0,4 \mathrm{~cm}$, coalescentes na base, a mediana ca. $1 \times 0,5 \mathrm{~cm}$; pétalas $0,8-1 \times$ $0,4-0,6 \mathrm{~cm}$, reflexas, espatuladas; labelo trilobado, amarelo, membranáceo, glabro, com calosidade carnosa claviforme de ápice fendido, glabro, lobos laterais 8,5-9 × 7-9 mm, reniforme, explanados, margem das axilas fimbriada, lobo mediano ca. 6 $\times 7 \mathrm{~mm}$, auriculado; coluna 3-5 $\times 2-3 \mathrm{~mm}$, livre, com projeções laterais, ventro-apicais, orbiculares; antera 1,5 × 1,9 mm, sem apêndice apical; polínias 2 , iguais, obovais.

Material examinado: Morro do Chapéu, Cachoeira do Ventura, 8.VIII.2003, fl., P.L. Ribeiro et al. 20 (HUEFS). Materiais adicionais: BRASIL. BAHIA: Quinjingue, Serra das Candeias, 15.V.2005, fl., D. Cardoso et al. 540 (HUEFS); Senhor do Bomfim, Serra da Maravilha, 11.VII.2005, fl., D. Cardoso et al. 642 (HUEFS).

Essa espécie foi reconhecida por Barros et al. (2010) como Alatiglossum barbatum (Lindl.) Baptista, sendo citada como endêmica para o 
Brasil, nos estados do Ceará, Rio Grande do Norte, Pernambuco, Bahia e Minas Gerais em Mata Atlântica. Adicionalmente é citada para o Paraná como Oncidium barbatum Lindl. (Angely 1965). Até então não havia sido registrada para a Chapada Diamantina, tendo sido coletada no município de Morro do Chapéu em áreas de caatinga, com flor em agosto.

Estudos com dados moleculares vêm indicando o polifiletismo da circunscrição tradicional de Oncidium Sw. (Williams et al. 2001). A partir desta informação, a maioria das espécies de Oncidium do Brasil foram segregadas para os gêneros Coppensia Dumort., Alatiglossum Baptista e Brasilidium Campacci (Docha Neto et al. 2006), usando como base para os grupos as seções de Pabst \& Dungs (1977). Algumas dessas seções, entretanto, não correspondem a grupos monofiléticos, e Chase et al. (2009) preferiram uma delimitação mais ampla deste grupo passando as espécies em questão para Gomesa, formando um grande grupo monofilético. Neste levantamento, preferimos utilizar esta circunscrição ampla, por ter sido a decisão dos autores que estudaram a filogenia do grupo, e por ser a adotada no Kew Monocot Checklist (Govaerts et al. 2006).

31. Gomesa blanchetii (Rchb.f.) M.W.Chase \& N.H.Williams, Ann. Bot. (Oxford) 104 (3): 396. 2009.

Rupícola ou terrícola, 0,7-1,3 m compr.; crescimento simpodial, cespitoso. Caule tipo pseudobulbo 4-5,5 × 0,8-1,9 cm, ovado, 2-foliado. Folhas com nervação paralela, $28-33 \times 0,8-1,6$ $\mathrm{cm}$, dísticas, lanceoladas, verdes, coriáceas, ápice agudo. Inflorescência lateral, 8-11 flores; pedúnculo 37,5-88,5 cm compr.; brácteas do pedúnculo 3-6, 0,8-1,4 cm compr., oblongas; raque $26,5-41,5 \mathrm{~cm}$ compr.; brácteas florais ca. $3 \mathrm{~mm}$ compr., lanceoladas. Flores monoclinas, ressupinadas, amarelas com máculas castanhas na face abaxial; pedicelo com ovário 1,7-2 cm compr.; sépalas reflexas, ovadas a lanceoladas, glabras, as laterais $0,7-1 \times 0,2-0,3 \mathrm{~cm}$, coalescentes na base, a mediana 7-9 × 2-4 mm; pétalas 6-8 $63-4 \mathrm{~mm}$, reflexas, inteiras, ovadas; labelo trilobado, todo amarelo, membranáceo, glabro, margem inteira, com calosidade carnosa formando cristas, glabra, pintalgada de castanho, lobos laterais 3-4×3-5 mm, auriculares, explanados, lobo mediano ca. $1 \times 1,2$ $1,6 \mathrm{~cm}$, reniforme bipartido; coluna ca. $4 \times 2 \mathrm{~mm}$, livre, com projeções latero-apicais, membranáceas, auriculadas e projeção frontal, carnosa, pendurada; antera $2 \times 1,5 \mathrm{~mm}$, sem apêndice apical; polínias 2 , iguais, ovais.

Material examinado: Morro do Chapéu, Morrão, 14.VIII.2008, fl., C.A. Bastos \& C. van den Berg 201 (HUEFS).

Citada como Coppensia blanchetii (Rchb.f.) Campacci por Barros et al. (2010), ocorre em Pernambuco, Bahia, Minas Gerais, São Paulo, Rio de Janeiro, Paraná e Santa Catarina, em Mata Atlântica. Na Chapada Diamantina é amplamente distribuída, registrada como Oncidium blanchetii Rchb.f. para Andaraí, Barra da Estiva, Catolés, Ibicoara, Jacobina, Lençóis, Mucugê, Palmeiras, Rio de Contas, Seabra e Serra do Sincorá. Em Morro do Chapéu, é encontrada em afloramento rochoso de campo rupestre. Floresce entre agosto e dezembro.

32. Gomesa gravesiana (Rolfe) M.W.Chase \& N.H.Williams, Ann. Bot. (Oxford) 104 (3): 397.2009. Epífita, 65-90 cm compr.; crescimento simpodial, subcespitoso. Caule tipo pseudobulbo 5-6 $\times 1,5-2,5 \mathrm{~cm}$, ovado, 2-foliado. Folhas com nervação paralela, 12,5-16 × 2-3,5 cm, dísticas, oblongas, verdes, cartáceas, ápice agudo. Inflorescência lateral, 5 a mais de 30 flores; pedúnculo $31-48 \mathrm{~cm}$ compr.; brácteas do pedúnculo $3-4,0,5-1,2 \mathrm{~cm}$ compr., lanceoladas; raque $17,2-55 \mathrm{~cm}$ compr.; brácteas florais ca. $3 \mathrm{~mm}$ compr., lanceoladas. Flores monoclinas, ressupinadas, predominantemente acastanhadas; pedicelo com ovário 2,7-3 cm compr.; sépalas reflexas, lanceoladas, glabras, as laterais $2,4-2,7 \times$ ca. $0,6 \mathrm{~cm}$, coalescentes na base, a mediana $2-2,5 \times 0,6-1 \mathrm{~cm}$; pétalas $2-2,5 \times 1,2-1,9 \mathrm{~cm}$, reflexas, inteiras, elípticas; labelo trilobado, amarelo com margem castanha, membranáceo, glabro, margem ondulada, com calosidade longitudinal, difusa, alada no ápice, oblíqua, longitudinalmente projetada no centro, 2 calos orbiculares na base e 1-3 dentículos ovados nas laterais, glabra, lobos laterais ca. $4 \times 6 \mathrm{~mm}$, auriculados, explanados, lobo mediano ca. 1,2 $\times 1,8 \mathrm{~cm}$, rômbico; coluna ca. $8 \times 4$ $\mathrm{mm}$, livre, com projeções laterais, membranáceas, auriculadas; antera $3 \times 2 \mathrm{~mm}$, sem apêndice apical; polínias 2, iguais, obovais.

Material examinado: Morro do Chapéu, Morrão, 14.III.1995, fl., L.P. Queiroz \& N.S. Nascimento 4288 (HUEFS),

Material adicional: BRASIL. BAHIA: Abaíra, Mata do Barbado, 3.II.1994, fl., W. Ganev 2940 (HUEFS).

Citada como Brasilidium gravesianum

(Rolfe) Campacci por Barros et al. (2010), essa 


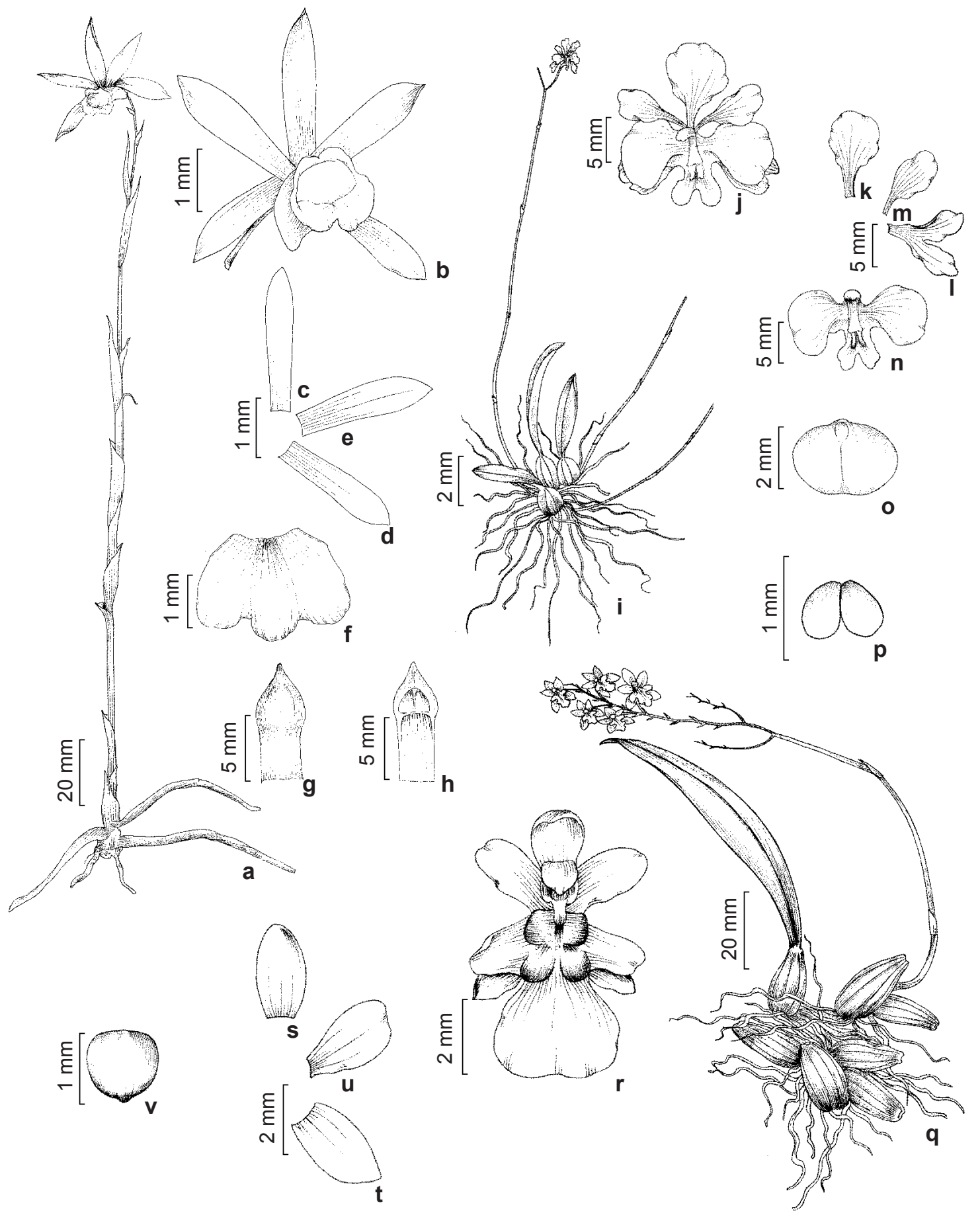

Figura 7 - a-h. Galeandra beyrichii - a. hábito; b. flor; c. sépala dorsal; d. sépala lateral; e. pétala; f. labelo explanado; g. coluna em vista dorsal; h. coluna em vista ventral. i-p. Gomesa barbata - i. hábito; j. flor ; k. sépala dorsal; 1. sépalas laterais; m. pétala; n. labelo; o. antera em vista dorsal; p. polínias. q-v. Gomesa hookeri-q. hábito; r. flor; s. sépala dorsal; t. sépala lateral; u. pétala; v. antera em vista dorsal. (a-h Bastos 226; i-p Ribeiro 20; q-v Borba 2069).

Figure 7 - a-h. Galeandra beyrichii - a. habit; b. flower; c. dorsal sepal; d. lateral sepal; e. petal; f. lip flattened out; g. column seen from above; h. column seen from beneath. i-p. Gomesa barbata - i. habit; j. flower; k. dorsal sepal; 1. lateral sepals; m. petal; n. lip; o. anther seen from above; p. pollinia. q-v. Gomesa hookeri-q. habit; r. flower; s. dorsal sepal; t. lateral sepal; u. petal; v. anther seen from above. (a-h Bastos 226; i-p Ribeiro 20; q-v Borba 2069). 
espécie, considerada endêmica do Brasil, ocorre em Pernambuco, Bahia, Minas Gerais, Espírito Santo, São Paulo, Rio de Janeiro, Paraná, Santa Catarina e Rio Grande do Sul, em Mata Atlântica. $\mathrm{Na}$ Chapada Diamantina foi encontrada em Catolés, Morro do Chapéu e Rio de Contas, sendo citada como Oncidium gravesianum Rolfe. No município de Morro do Chapéu, ocorre em áreas de floresta sobre tronco de árvores, com flor em março.

33. Gomesa hookeri (Rolfe) M.W.Chase \& N.H.Williams, Ann. Bot. (Oxford) 104 (3): 397. 2009.

Fig. $7 \mathrm{q}-\mathrm{v}$

Rupícola, 13-18,6 cm compr.; crescimento simpodial, cespitoso. Caule tipo pseudobulbo 1,8-3,4 × 0,7-1,2 cm, ovado, 2-foliado. Folhas com nervação paralela, $8-10 \times$ ca. $1 \mathrm{~cm}$, dísticas, oblongas, verdes, cartáceas, ápice agudo. Inflorescência lateral, ca. 20 flores; pedúnculo 5,6-6,7 cm compr.; brácteas do pedúnculo 1-2, 3-5 mm compr.; raque 5,2-8,5 cm compr.; bráctea floral 0,8-2 mm compr., lanceolada. Flores monoclinas, não ressupinadas, amarelas predominatemente com máculas castanhas; pedicelo com ovário 3-6 mm compr.; sépalas reflexas, lanceoladas, glabras, as laterais 2,3-4 × 0,8-1 mm, coalescentes na base, a mediana 1,8-3 × 1-1,6 mm; pétalas 2,5-4 × 0,6-2 $\mathrm{mm}$, reflexas, inteiras, lanceoladas; labelo trilobado, amarelo, membranáceo, glabro, margem inteira, com calosidade carnosa, uniforme, orbicular, glabro, fendida na base e nas laterais, lobos laterais 1,2-2,5 $\times$ 1-2 mm, ovados, explanados, lobo mediano 1,7-3,5 $\times 1,7-3,7 \mathrm{~mm}$, obovado; coluna ca. $1 \times 1 \mathrm{~mm}$, livre, com projeções laterais, orbiculares; antera 0,8-1 $\times 1$ $\mathrm{mm}$, sem apêndice apical; polínias 2 , iguais, ovais. Material examinado: Morro do Chapéu, Morrão, 13.XI.2008, fl., C.A. Bastos \& J. B. Pinto 272 (HUEFS).

Endêmica do Brasil, essa espécie foi citada como Coppensia hookeri (Rolfe) F.Barros \& L.Guimarães por Barros et al. (2010) para os estados da Bahia, Minas Gerais, São Paulo, Rio de Janeiro, Paraná e Rio Grande do Sul, em Mata Atlântica. Na Chapada Diamantina, foi coletada em Lençóis e Palmeiras, sendo citada como Oncidium hookeri Rolfe. No município de Morro do Chapéu ocorre em afloramentos rochosos em mata de grotão. Floresce em novembro.

34. Gomesa varicosa (Lindl.) M.W.Chase \& N.H.Williams, Ann. Bot. (Oxford) 104 (3): 398. 2009.

Terrícola ou rupícola, 0,9-1,3 m compr.; crescimento simpodial, cespitoso. Caule tipo pseudobulbo 5,5-8,6 × 1-1,5 cm, ovado, 2-foliado.
Folhas com nervação paralela, 13,5-20 × 1,2-2,5 $\mathrm{cm}$, dísticas, oblongas, verdes, cartáceas, ápice agudo. Inflorescência lateral, 5 a mais de 30 flores; pedúnculo $0,7-1 \mathrm{~m}$ compr; brácteas do pedúnculo 4-5, 0,7-1,3 cm compr., lanceoladas; raque 10-22 cm compr.; brácteas florais 2-3 mm compr., lanceoladas. Flores monoclinas, ressupinadas, amarelas com máculas castanhas; pedicelo com ovário 1,6-3,2 cm compr.; sépalas reflexas, lanceoladas, glabras, as laterais $8-9 \times$ ca. $3 \mathrm{~mm}$, coalescentes na base, a mediana 7-8 $\times 2-4 \mathrm{~mm}$; pétalas ca. $7 \times$ 2,5-4,5 mm, reflexas, inteiras, oblongas; labelo trilobado, todo amarelo, membranáceo, glabro, margem inteira, com calosidade triangular, difusa, centro hastado, ápice tripartido, laterais superiores multidentadas, glabra, lobos laterais 2-5 × 3-6 mm, auriculados, explanados, lobo mediano $1,2-2 \times 2-3 \mathrm{~cm}$, reniforme tetrapartido; coluna 5-7 $\times 2-5 \mathrm{~mm}$, livre, com projeções lateroapicias, membranáceas, auriculadas e frontal carnosa, quadrada fendida no centro; antera 2,5-3 $\times 1,5-2,5 \mathrm{~mm}$, sem apêndice apical; polínias 2 , iguais, obovais.

Materiais examinados: Morro do Chapéu, Buraco Dona Duda, 19.IV.2008, fl., E. Melo et al. 5609 (HUEFS); Buraco do Possidônio, 17.IV.2008, fl., E. Melo et al. 5537 (HUEFS).

Considerada endêmica do Brasil, Barros et al. (2010) citaram como Coppensia varicosa (Lindl.) Campacci para Bahia, Goiás, Minas Gerais e São Paulo, em áreas de Cerrado e Mata Atlântica. Adicionalmente, foi citada para o Paraná como Oncidium varicosum Lindl. (Angely 1965). $\mathrm{Na}$ Chapada Diamantina, sob esse último nome, há registros para os municípios de Abaíra, Érico Cardoso, Lençóis, Palmeiras e Rio de Contas. Em Morro do Chapéu, foi coletada em áreas de caatinga. Floresce de abril a julho.

35. Habenaria fluminensis Hoehne, Arq. Bot. Estado São Paulo 1: 41. $1939 . \quad$ Fig. 8a-f

Terrícola, 38,5-76 cm compr.; crescimento simpodial, sub-cespitoso. Caule tipo cauloma 28-65 × 0,3-0,4 cm, cilíndrico, 8-foliado. Folhas com nervação paralela, 9,5-14,5 × ca. $1 \mathrm{~cm}$, espiraladas, lanceoladas, verdes, membranáceas, ápice agudo. Inflorescência apical, ca. 8 flores; pedúnculo inconspícuo; raque $11-12 \mathrm{~cm}$ compr; brácteas florais 2,1-2,5 cm compr., lanceoladas. Flores monoclinas, ressupinadas, esverdeadas; ovário ca. 2,7 cm compr.; sépalas eretas, oblongas a ovadas, glabras, as laterais ca. 1,5 ×0,5 cm, livres entre si, a mediana $1-1,3 \times 0,4-0,7 \mathrm{~cm}$; pétalas 
eretas, bipartidas, segmento anterior ca. $8,6 \mathrm{~mm}$ compr., lanceolado, segmento posterior ca. 7,3 mm compr., linear; labelo tripartido, esverdeado, membranáceo, glabro, margem inteira; segmentos laterais ca. 1,4× 0,1 cm, acerosos, perpendiculares ao lobo mediano; segmento mediano $1,1-1,3 \times 0,4-0,7 \mathrm{~cm}$, estreitooblongo; cálcar ca. 1,3×0,1 cm, linear; coluna ca. $5 \times 4,8-5,3 \mathrm{~mm}$, livre.

Materiais examinados: Morro do Chapéu, BA 052, 4.III.1977, fl., R.M. Harley 19380 (CEPEC); 17.VI.1981, fl., S.A. Mori et al. 14508 (CEPEC); Cachoeira do Ferro Doido, 31.III.1980, fl., R.M. Harley 22896 (CEPEC, K).

Endêmica do Brasil, ocorre nos estados da Bahia, Minas Gerais, Espírito Santo, São Paulo e Rio de Janeiro, em áreas de Caatinga, Cerrado e Mata Atlântica. Na Bahia foi registrada apenas para a Chapada Diamantina, nos municípios de Morro do Chapéu e Mucugê. Em Morro do Chapéu é encontrada em áreas de mata ciliar. Floresce de março a junho.

36. Habenaria josephensis Barb.Rodr., Gen. Sp. Orchid. 2: 257. 1881 Fig. 8g-m

Terrícola, 39-65,5 cm compr.; crescimento simpodial, sub-cespitoso. Caule tipo cauloma 31-49 $\times 0,3-0,4 \mathrm{~cm}$, cilíndrico, 12-18-foliado. Folhas com nervação paralela, 4,3-9 × 0,8-2 cm, espiraladas, lanceoladas, verdes, membranácea, ápice agudo. Inflorescência apical, 14-24 flores; pedúnculo inconspícuo; raque 8-16 cm compr.; brácteas florais ca. $1,5 \mathrm{~cm}$ compr., lanceoladas. Flores monoclinas, ressupinadas, esverdeadas; ovário 1-1,7 cm compr.; sépalas eretas, oblongas a ovadas, glabras, as laterais 5,5-7,5 × ca. $3 \mathrm{~mm}$, livres entre si, a mediana ca. 5,5 $\times$ 2,1-4 mm; pétalas eretas, bipartidas, segmento anterior ca. 4,2 mm compr., lanceolado, segmento posterior ca. $1 \mathrm{~mm}$ compr., lanceolado; labelo tripartido, esverdeado, membranáceo, glabro, margem inteira; segmentos laterais ca. $1 \times 0,5 \mathrm{~mm}$, oblongos, deflexos; segmento mediano $7-8 \times$ ca. $0,6 \mathrm{~mm}$, oblongo; cálcar $1-1,3 \times$ ca. $0,1 \mathrm{~cm}$, linear; coluna 2-3 $\times 1-2,5 \mathrm{~mm}$, livre.

Materiais examinados: Morro do Chapéu, estrada para Bonito, 30.III.1980, fl., R.M. Harley 22750 (K, SPF); estrada para o Morrão, 5.VII.2001, f1., F.R. Nonato 989 (HUEFS, HRB).

Endêmica do Brasil, ocorre na Paraíba, Pernambuco, Bahia, Alagoas, Sergipe, Minas Gerais, Espírito Santo, São Paulo, Rio de Janeiro, Paraná, Santa Catarina e Rio Grande do Sul, no domínio fitogeográfico da Mata Atlântica. Na Chapada Diamantina não havia sido registrada até o momento, sendo encontrada em Morro do Chapéu em áreas úmidas, frequentemente dentro de florestas. Floresce de março a julho.
37. Habenaria parviflora Lindl., Gen. Sp. Orchid. P1. 314. 1835.

Fig. 8n-s

Terrícola, 10-40 cm compr.; crescimento simpodial, sub-cespitoso. Caule tipo cauloma 16-33 $\times$ ca. $0,3 \mathrm{~cm}$, cilíndrico, 6-8-foliado. Folhas com nervação paralela, 5-11 × 1-2 cm, espiraladas, lanceoladas, verdes, membranáceas, ápice agudo. Inflorescência apical, 12-20 flores; pedúnculo inconspícuo; raque 3,4-7,4 cm compr.; brácteas florais 6-8 mm compr., lanceoladas. Flores monoclinas, ressupinadas, amarelo-esverdeadas; ovário $6,5-8 \mathrm{~mm}$ compr.; sépalas eretas, oblongas a ovadas, glabras, as laterais $2-3 \times$ ca. $0,5 \mathrm{~mm}$, livres entre si, a mediana 3-4 × ca. $1 \mathrm{~mm}$; pétalas eretas, bipartidas, segmento anterior 3,5-4,5 mm compr., lanceolado, segmento posterior 1,2-2,1 mm compr., linear; labelo tripartido, amarelado a esverdeado, membranáceo, glabro, margem inteira; segmentos laterais $2-3 \times$ ca. $0,5 \mathrm{~mm}$, acerosos, deflexos; segmento mediano 3-3,9 $\times$ ca. 1,2 $\mathrm{mm}$, lanceolado; cálcar 6,5-8,5 ×0,8-1,1 mm, linear; coluna 1,3-2 × 0,8-1,4 mm, livre.

Materiais examinados: Morro do Chapéu, estrada para Bonito, 30.III.1980, fl., R.M. Harley 22810 (CEPEC, K, SPF); 2.VI.1980, fl., R.M. Harley 23016 (CEPEC, K).

Ocorre de Norte a Sul do Brasil, em Caatinga, Cerrado e Mata Atlântica. É citada para a Chapada Diamantina por van den Berg \& Azevedo (2005), mas sem identificar as localidades. No município de Morro do Chapéu foi coletada em área de pântano, com flor nos meses de março e abril.

38. Habenaria repens Nutt., Gen. N. Amer. Pl. 2: 190. 1818. Fig. 8t-y

Terrícola, 17,4-43 cm compr.; crescimento simpodial, sub-cespitoso. Caule tipo cauloma 12$30 \times$ ca. $0,3 \mathrm{~cm}$, cilíndrico, 5-8-foliado. Folhas com nervação paralela, $8-11 \times 0,8-1 \mathrm{~cm}$, espiraladas, lanceoladas, verdes, membranáceas, ápice agudo. Inflorescência apical, 8 a mais de 30 flores; pedúnculo inconspícuo; raque 4,5-13,5 cm compr.; brácteas florais $0,7-2 \mathrm{~cm}$ compr., lanceoladas. Flores monoclinas, ressupinadas, esverdeadas; ovário 1-1,3 cm compr.; sépalas oblongas a ovadas, glabras, as laterais ca. $5 \times 2-3 \mathrm{~mm}$, reflexas, livres entre si, a mediana 4-5 × 2,7-4 mm, ereta; pétalas eretas, bipartidas, segmento anterior ca. $1,7 \mathrm{~mm}$ compr., lanceolado, segmento posterior ca. $5,5 \mathrm{~mm}$ compr., lanceolado; labelo tripartido, esverdeado, membranáceo, glabro, margem inteira; segmentos laterais 3,7-5,2 ×0,3-0,5 mm, oblongos, deflexos; segmento mediano $3,5-5,7 \times$ ca. $0,8 \mathrm{~mm}$, oblongo; cálcar 6-8, $3 \times 0,5-0,8 \mathrm{~mm}$, linear; coluna 1,6-3,5 $\times 1,5-2,3 \mathrm{~mm}$, livre. 


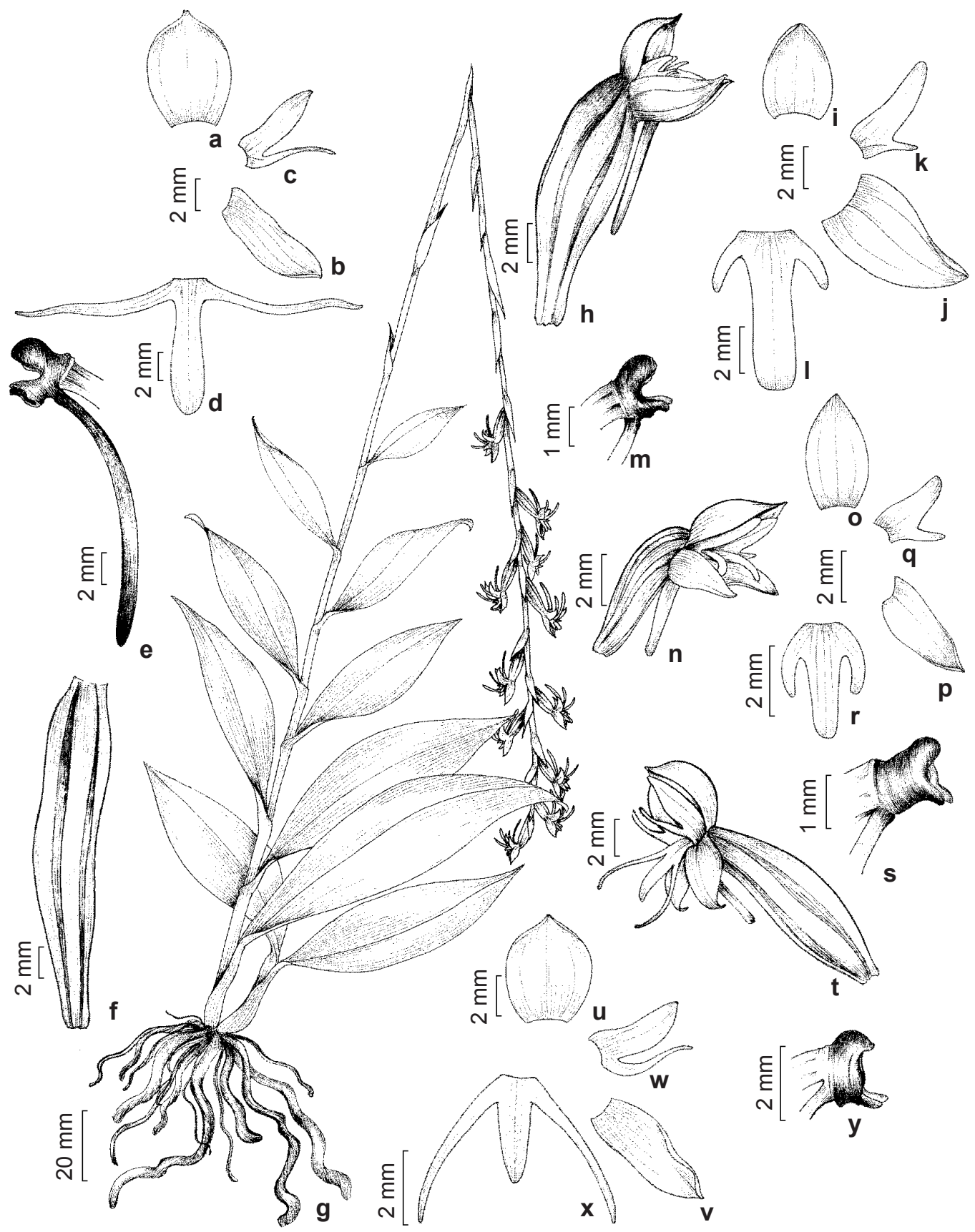

Figura 8 - a-f. Habenaria fluminensis - a. sépala dorsal; b. sépala lateral; c. pétala; d. labelo; e. coluna, calcar e porção do ovário em vista lateral; f. ovário. g-m. Habenaria josephensis - g. hábito; h. flor; i. sépala dorsal; j. sépala lateral; k. pétala; 1. labelo; m. coluna, porção do calcar e porção do ovário em vista lateral. n-s. Habenaria parviflora -n. flor; o. sépala dorsal; p. sépala lateral; q. pétala; r. labelo; s. coluna, porção do calcar e porção do ovário em vista lateral. t-y. Habenaria repens - t. flor; u. sépala dorsal; v. sépala lateral; w. pétala; $x$. labelo; y. coluna, porção do calcar e porção do ovário em vista lateral. (a-f Mori 14508; g Mori 14459, h-m Mori 14459, Hatschabach 42403; n-s Guimarães 42358, Harley 19284; t-y Harley 23016).

Figure 8 - a-f. Habenaria fluminensis - a. dorsal sepal; b. lateral sepal; c. petal; d. lip; e. column, part of spur and part of ovary in side view; f. ovary. g-m. Habenaria josephensis - g. habit; h. flower; i. dorsal sepal; j. lateral sepal; k. petal; 1. lip; m. column, part of spur and part of ovary in side view. n-s. Habenaria parviflora - n. flower; o. dorsal sepal; p. lateral sepals; q. petal; r. lip; s. column, part of spur and part of ovary in side view. t-y. Habenaria repens - t. flower; u. dorsal sepal; v. lateral sepal; w. petal; $x$. lip; $y$. column, part of spur and part of ovary in side view. (a-f Mori 14508; g Mori 14459, h-m Mori 14459, Hatschabach 42403; n-s Guimarães 42358, Harley 19284; t-y Harley 23016). 
Materiais examinados: Morro do Chapéu, BA 052, 2.III.1977, fl., R.M. Harley et al. 19284 (K, MBM, SPF); Serra do Tombador, 15.VII.1979, fl., G. Hatschbach \& O. Guimarães 42358 (CEPEC, RB); Rio Ventura, 27.VI.1996, fl., R.M. Harley et al. 3114 (ALCB).

Ocorre nos estados do Pará, Bahia, Distrito Federal, Minas Gerais, São Paulo, Rio de Janeiro, Paraná, Santa Catarina e Rio Grande do Sul, nos domínios fitogeográficos da Amazônia, Caatinga, Cerrado e Mata Atlântica. Na Bahia foi citada para Mucugê e Morro do Chapéu, onde é encontrada em áreas úmidas próximas a córregos. Floresce de março a julho.

É similar a $H$. amambayensis Schltr., mas distingue-se desta pelas flores pequenas e segmentos laterais das sépalas e labelo mais curtos. Trata-se de uma espécie tipicamente aquática, que cresce dentro da água nas margens de lagos ou áreas inundadas, presa na vegetação aquática ou flutuando, sobre tronco de árvores mortas (Batista et al. 2008).

39. Isabelia violacea (Lindl.) Van den Berg \& M.W.Chase, Lindleyana 16(2): 109. 2001. Fig. 9a-f Epífita, ca. $6 \mathrm{~cm}$ compr.; crescimento simpodial, subcespitoso. Caule tipo pseudobulbo ca. 1,5 $\times 0,6 \mathrm{~cm}$, ovado, 1-foliado. Folha paralelinérvea, ca. $3 \times 0,5 \mathrm{~cm}$, oblonga, verde, coriácea, ápice agudo. Inflorescência apical, ca. 3 flores; pedúnculo ca. $0,7 \mathrm{~cm}$ compr.; brácteas do pedúnculo 2 , ca. $1 \mathrm{~cm}$ compr., ovadas a lanceoladas; raque ca. $3 \mathrm{~cm}$ compr.; brácteas florais ca. $9 \mathrm{~mm}$ compr., lanceoladas. Flores monoclinas, ressupinadas, violetas; sépalas eretas, oblongas, glabras, as laterais livres entre si; pétalas eretas, inteiras, oblongas; labelo inteiro, deltóide, violeta, membranáceo, glabro, margem inteira.

Material examinado: Morro do Chapéu, Morrão, 27.X.1978, fl., fr., G. Martinelli et al. 5221 (RB).

Endêmica do Brasil, ocorre na Bahia, Goiás, Distrito Federal, Minas Gerais, São Paulo, Rio de Janeiro, Paraná, Santa Catarina e Rio Grande do Sul, em Cerrado e Mata Atlântica. Na Chapada Diamantina é citada sem localidade específica por Toscano de Brito \& Cribb (2005). No Morro do Chapéu foi coletada sobre tronco de árvore, provavelmente em mata de grotão no entorno do campo rupestre do Morrão. Frutifica no mês de outubro, sendo possível ser encontrada com flor desde julho.

40. Isochilus linearis (Jacq.) R.Br., Hortus Kew. 2 (5): 209. 1813.

Epífita, 29-33 cm compr.; crescimento simpodial, cespitoso. Caule tipo cauloma 26-32 $\times$ ca. 0,2 cm, linear, 11-14-foliado. Folhas com nervação paralela, ca. $3 \times 0,4 \mathrm{~cm}$, espiraladas, linear-oblongas, verdes, membranáceas, ápice retuso. Inflorescência apical, 3 flores; pedúnculo inconspícuo; raque 1,31,5 cm compr.; brácteas florais inconspícuas. Flores monoclinas, ressupinadas, róseas; pedicelo com ovário ca. 4 mm compr.; sépalas eretas, lanceoladas, glabras, as laterais ca. 4,7 $\times 2,2 \mathrm{~mm}$, coalescentes na base, a mediana ca. 4,2 $\times 1,2 \mathrm{~mm}$; pétalas ca. $5 \times 1$ $\mathrm{mm}$, eretas, inteiras, lanceoladas; labelo inteiro, ca. 4,5 × $1 \mathrm{~mm}$, genuflexo, rosa, membranáceo, glabro, margem inteira; coluna ca. 2,5 $\times 0,5 \mathrm{~mm}$, livre, com projeções lineares; antera $0,1 \times 0,1 \mathrm{~mm}$, sem apêndice apical; polínias 2, iguais, ovais.

Material examinado: Morro do Chapéu, Buraco da Duda, 12.VII.2008, fl., fr., E. Melo 5844 (HUEFS).

Material adicional: BRASIL, BAHIA: Andaraí, Trilha para a Cachoeira do Ramalho, VIII.2001, fl., F.R. Nonato et al. 1014 (HUEFS).

Ocorre na Bahia, Distrito Federal, Mato Grosso do Sul, Minas Gerais, São Paulo, Rio de Janeiro, Paraná, Santa Catarina e Rio Grande do Sul, em áreas de Cerrado e Mata Atlântica. Na Chapada Diamantina foi citada para os municípios de Abaíra, Andaraí, Palmeiras e Rio de Contas. Em Morro do Chapéu foi coletada em floresta sobre tronco de árvore, com flor em julho.

41. Notylia pubescens Lindl., Edwards's Bot. Reg. 28 (Misc.): 62.1842.

Epífita, 14-15,5 cm compr.; crescimento simpodial, subcespitoso. Caule tipo pseudobulbo 1,3-3 × ca. 0,6 cm, ovado, 1-foliado. Folha paralelinérvea, ca. $11 \times 1,5-2,5 \mathrm{~cm}$, oblonga a lanceolada, verde, coriácea, ápice agudo. Inflorescência lateral, ca. 30 flores; pedúnculo 2,6-5,7 cm compr.; brácteas do pedúnculo 3-4, 8-9 mm compr., lanceoladas; raque 5,5-8,3 cm compr.; brácteas florais ca. $5 \mathrm{~mm}$ compr., lanceoladas. Flores monoclinas, ressupinadas, cremes; pedicelo com ovário 7-8 mm compr.; sépalas eretas, lanceoladas, glabras, as laterais 5,9-7,2 × 1,2-1,5 mm (juntas), coalescentes, a mediana 7-8,5 × ca. 1,5 mm; pétalas 6,3-7,5 × 1,1-1,4 mm, eretas, inteiras, lanceoladas; labelo inteiro, 5,5-6,5 × 1,6-2 mm, hastado, creme, membranáceo, glabro, margem inteira; coluna ca. $4 \times$ 0,8-1,2 mm, livre; antera $2 \times 1,2 \mathrm{~mm}$, sem apêndice apical; polínias 2, iguais, ovais.

Materiais examinados: Morro do Chapéu, estrada para Bonito, 18.IX.2008, fl., C.A. Bastos 262 (HUEFS); X.2008, fl., C.A. Bastos \& J.B. Pinto 243 (HUEFS).

Endêmica do Brasil, ocorre no Ceará, Bahia, Minas Gerais, Rio de Janeiro, Paraná, Santa Catarina e Rio Grande do Sul em Mata Atlântica. $\mathrm{Na}$ Chapada Diamantina foi registrada em Rio de 


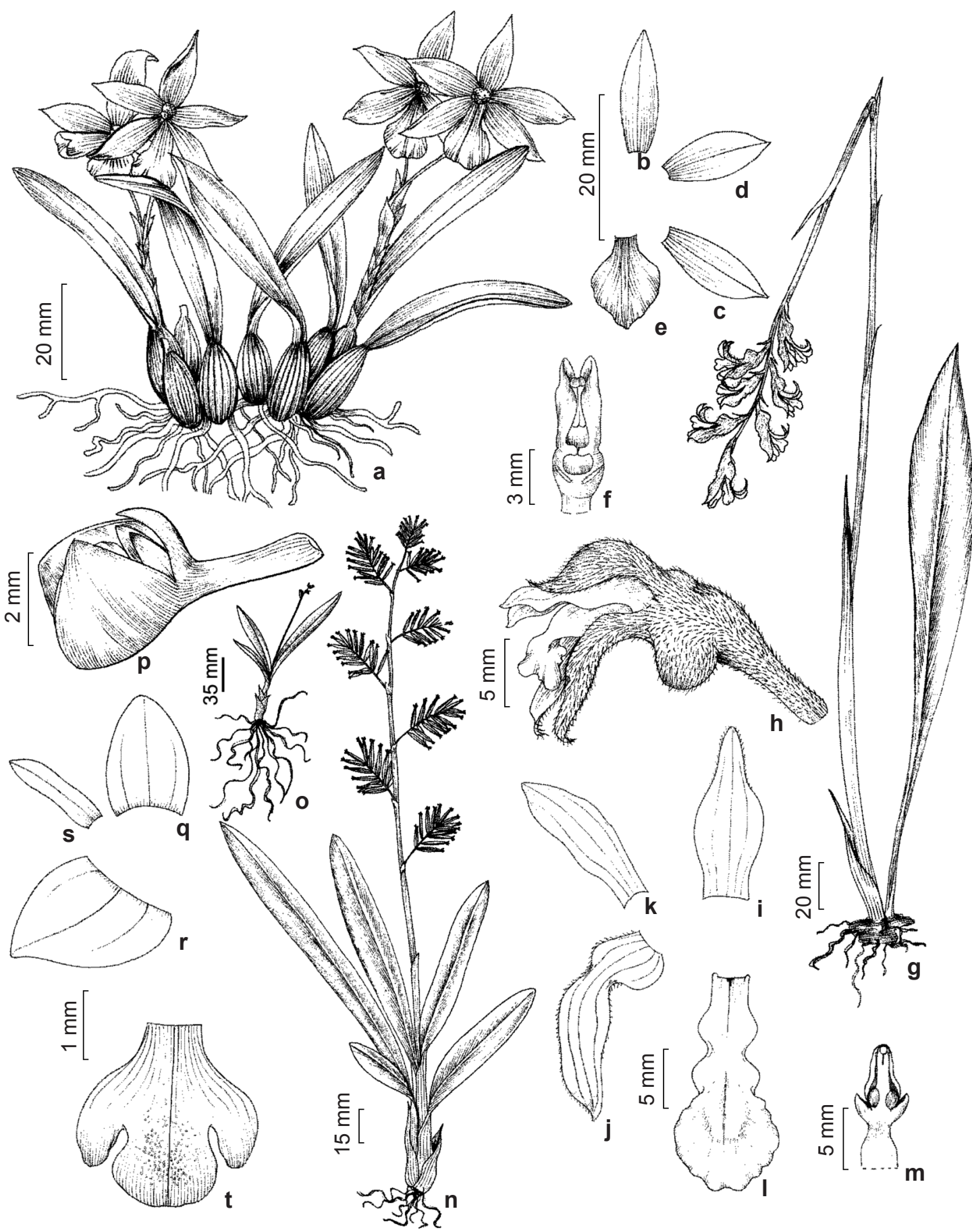

Figura 9 - a-f. Isabelia violacea - a. hábito; b. sépala dorsal; c. sépala lateral; d. pétala; e. labelo; f. coluna em vista ventral. g-m. Pelexia orthosepala - g. hábito; h. flor; i. sépala dorsal; j. sépala lateral; k. pétala; 1 . labelo; m. coluna em vista ventral. n-t. Polystachya estrellensis - n-o. hábito; p. flor; q. sépala dorsal; r. sépala lateral; s. pétala; t. labelo. (a-f Martinelli 5221; g-m Costa s.n. (ALCB 7252); n Melo 5223, o Bastos 166, p-t Bastos 166).

Figure 9 - a-f. Isabelia violacea - a. habit; b. dorsal sepal; c. lateral sepal; d. petal; e. lip; f. column seen from beneath. g-m. Pelexia orthosepala g. habit; h. flower; i. dorsal sepal; j. lateral sepal; k. petal; 1. lip; m. column seen from beneath. n-t. Polystachya estrellensis - n-o. habit; p. flower; q. dorsal sepal; r. lateral sepal; s. petal; t. lip. (a-f Martinelli 5221; g-m Costa s.n. (ALCB 7252); n Melo 5223, o Bastos 166, p-t Bastos 166). 
Contas. Foi encontrada sobre tronco de árvores em áreas de floresta no município de Morro do Chapéu. Floresce nos meses de setembro e outubro.

42. Octomeria hatschbachii Schltr., Repert. Spec. Nov. Regni Veg. 23: 45. 1926.

Epífita, ca. 12,7 cm compr.; crescimento simpodial, subcespitoso. Caule tipo cauloma ca. 4,7 $\times 0,3 \mathrm{~cm}$, cilíndrico, 1-foliado. Folha paralelinérvea, ca. $8,4 \times 0,5 \mathrm{~cm}$, linear-oblonga, subcilíndrica, verde, carnosa, ápice agudo. Inflorescência apical, ca. 4 flores; pedúnculo inconspícuo; raque ca. $2 \mathrm{~cm}$ compr.; brácteas florais ca. $3 \mathrm{~mm}$ compr., oblongas. Flores monoclinas, ressupinadas, predominantemente amareladas; pedicelo com ovário ca. 3,7 mm compr.; sépalas eretas, lanceoladas, glabras, as laterais ca. $7 \times 2 \mathrm{~mm}$, livres entre si entre si, a mediana ca. $7 \times 2,5 \mathrm{~mm}$; pétalas eretas, ca. $6 \times 1 \mathrm{~mm}$, inteiras, lanceoladas; labelo trilobado, amarelo, membranáceo, glabro, margem inteira, lobos laterais ca. 0,9 $\times 0,4 \mathrm{~mm}$, arredondados, eretos, lobo mediano ca. $0,5 \times$ $1,2 \mathrm{~mm}$, suborbicular; coluna ca. 1,7 $\times 0,5 \mathrm{~mm}$, livre; antera $0,7 \times 0,7 \mathrm{~mm}$, sem apêndice apical; polínias 8 , iguais, elípticas.

Material examinado: Morro do Chapéu, Morrão, 9.VIII.2003, fl., P. L. Ribeiro et al. 28 (HUEFS).

Endêmica do Brasil, há registros para a Bahia, São Paulo, Rio de Janeiro, Paraná e Santa Catarina, em áreas de Caatinga e Mata Atlântica. Na Chapada Diamantina foi citada para Catolés e Rio de Contas. É encontrada em Morro do Chapéu em áreas de floresta sobre tronco de árvores. Floresce em agosto.

43. Oeceoclades maculata (Lindl.) Lindl., Gen. Sp. Orchid. Pl. 237. 1833.

Terrícola, 24-37,5 cm compr.; crescimento simpodial, cespitoso. Pseubobulbo 2,6-3 × 0,5$0,7 \mathrm{~cm}$, ovado, 1-foliado. Folhas com nervação paralela, 21,5-29 × 3,5-4 cm, isolada, oblonga, verde-escura maculada de verde-claro, coriácea, ápice agudo. Inflorescência lateral, 8-9 flores; pedúnculo 18,5-29 $\mathrm{cm}$ compr.; brácteas do pedúnculo 5, 2-3,2 cm compr., lanceoladas; raque 6,5-14 cm compr.; brácteas florais ca. $6 \mathrm{~mm}$ compr., lanceoladas. Flores monoclinas, ressupinadas, branco-acastanhadas; pedicelo com ovário 1,4-3 cm compr.; sépalas eretas, lanceoladas, glabras, as laterais ca. $3 \times 2 \mathrm{~mm}$, livres entre si, a mediana ca. $4 \times 7-8 \mathrm{~mm}$; pétalas ca. $12 \times 3 \mathrm{~mm}$, eretas, inteiras, lanceoladas; labelo trilobado, branco com traços rosa, membranáceo, glabro, margem inteira, lobos laterais ca. $3 \times 2 \mathrm{~mm}$, elípticos, explanados, lobo mediano ca. $4 \times 8 \mathrm{~mm}$, reniforme; cálcar ca. $5 \times 1$ $\mathrm{mm}$, obovado; coluna ca. $4 \times 1 \mathrm{~mm}$, livre.

Material examinado: Morro do Chapéu, Cachoeira do Ferro Doido, 27.IV.1999, fr., R.C. Forzza et al. 1376 (CEPEC, SPF).

Materiais adicionais: BRASIL. BAHIA: Feira de Santana, 14.IX.2004, fl., S.F. Conceição et al. 28 (HUEFS); 5.V.2007, fl., E. Melo et al. 4749 (HUEFS); 19.VIII.2007, fl., E. Melo et al. 4990 (HUEFS); Maracás, 23.IV.2002, fl., E.R. Souza et al. 167 (HUEFS).

Ocorre em todo o Neotrópico nos mais variados domínios fitogeográficos. No Brasil se distribui de norte a sul (Barros et al. 2010). Parece ser comum na Chapada Diamantina, registrada para os municípios de Abaíra, Jacobina, Palmeiras e Rio de Contas. Encontrada em Morro do Chapéu em áreas de floresta, com flor em abril.

44. Pelexia orthosepala (Rchb.f. \& Warm.) Schltr., Beih. Bot. Centralbl. 37(2): 404. 1920. Fig. 9g-m

Terrícola, 50,5-61 cm compr.; crescimento simpodial, cespitoso. Caule tipo cauloma inconspícuo, 1-foliado. Folha paralelinérvea, ca. $23,5 \times 1,5 \mathrm{~cm}$, lanceolada, verde, membranácea, ápice agudo. Inflorescência apical, 5-8 flores; pedúnculo 43,5-47,5 cm compr.; brácteas do pedúnculo 5-6, 4,3-5 cm compr., lanceoladas; raque 7,3-9,2 cm compr.; brácteas florais 1,4-2 cm compr., lanceoladas. Flores monoclinas, ressupinadas, esverdeadas; ovário ca. $3 \mathrm{~mm}$ compr.; sépalas lanceoladas, pilosas, as laterais ca. 1,6 ×0,4 cm, eretas, levemente revolutas, coalescentes na base, a mediana ca. $1,4 \times 0,5 \mathrm{~cm}$, ereta; pétalas ca. $1,8 \times$ $0,4 \mathrm{~cm}$, eretas, inteiras, lanceoladas; labelo trilobado, esverdeado, membranáceo, glabro, margem inteira, lobos laterais ca. $4 \times 1 \mathrm{~mm}$, ovados, explanados, lobo mediano ca. $8 \times 5,2 \mathrm{~mm}$, arredondado; coluna ca. 7 $\times 2 \mathrm{~mm}$, livre; antera $1,8 \times 1,5 \mathrm{~mm}$, sem apêndice apical; polínias 2, iguais, obovais.

Material examinado: Morro do Chapéu, sem local, 17.V.1975, fl., A.L. Costa \& G.M. Barroso (ALCB 7252).

Material adicional: BRASIL. BAHIA: Mucugê, Mucugê-Guiné, X.2005, fl., E.C. Smidt et al. 662 (HUEFS).

Endêmica do Brasil, ocorre na Bahia, Distrito Federal, Minas Gerais e Paraná, em Caatinga, Cerrado e Mata Atlântica. Adicionalmente há registros para os estado de Goiás e São Paulo (Pabst \& Dungs 1975). Na Chapada Diamantina, há registro nos municípios de Morro do Chapéu e Rio de Contas. Em Morro do Chapeú a única coleta não trazia dado de ambiente de ocorrência do material. Foi coletada com flor em maio. 
45. Polystachya estrellensis Rchb.f., Linnaea 25: 231. 1852.

Fig. 9n-t

Epífita, 15-31,5 cm compr.; crescimento simpodial, subcespitoso. Caule tipo pseudobulbo 2-4,5 × 0,3-0,5 cm, ovado, 2-3-foliado. Folhas com nervação paralela, 7,2-14,5 × 0,6-1,7 cm, espiraladas, oblongas, verdes, cartáceas, ápice agudo. Inflorescência apical, 8 a mais de 30 flores; pedúnculo 4,8-13 cm compr.; brácteas do pedúnculo $1-2,2-7,5 \mathrm{~cm}$ compr., lanceoladas; raque 2-21,4 $\mathrm{cm}$ compr.; brácteas florais ca. $1 \mathrm{~mm}$ compr., lanceoladas. Flores monoclinas, não ressupinadas, esverdeadas; pedicelo com ovário ca. $4 \mathrm{~mm}$ compr.; sépalas eretas, ovadas, glabras, as laterais ca. $4 \times 3,8$ $\mathrm{mm}$, coalescentes na base, a mediana ca. 2,5 $2 \mathrm{~mm}$; pétalas ca. $2 \times 0,7 \mathrm{~mm}$, eretas, inteiras, oblongas; labelo trilobado, esverdeado, membranáceo, glabro, margem inteira, com calos papilosos, lobos laterais ca. $0,6 \times 0,6 \mathrm{~mm}$, ovados, revolutos, lobo mediano ca. $1,5 \times 1,8 \mathrm{~mm}$, rotundo; coluna ca. $1,9 \times 1 \mathrm{~mm}$, livre. Materiais examinados: Morro do Chapéu, Buraco do Possidônio, 5.III.2008, fr., C.A. Bastos 140 (HUEFS); estrada para o Buraco do Possidônio, 5.III.2008, fr., C.A. Bastos 128 (HUEFS); Fazenda Guariba, 12.X.2007, fr., E. Melo \& B.M. Silva 5223 (HUEFS); Morrão, 7.IV.2008, fl., C. A. Bastos 166 (HUEFS).

Ocorre de norte a sul do Brasil, sendo reconhecida como endêmica por Barros et al. (2010). É encontrada nos mais variados tipos vegetacionais. Não há registro para a Chapada Diamantina, mas provavelmente ocorre em Lençóis e Rio de Contas, tendo sido citada como Polysthachia concreta (Jacq.) Garay \& H.R.Sweet (Toscano de Brito 1998; Toscano de Brito \& Cribb 2005), com a qual é comumente confundida pela semelhança na morfologia vegetativa e floral. No entanto, $P$. concreta apresenta sépalas mais angulosas e defexas e o ápice das pétalas mais afilado, além dos lobos laterais do labelo serem subquadráticos (Pansarin \& Amaral 2006). No município de Morro do Chapéu, foi coletada sobre tronco de árvores em áreas de floresta. Floresce de outubro a abril.

46. Prescottia leptostachya Lindl., Edwards's Bot. Reg. 23: sub t. 1915. 1836.

Fig. 10a-f

Terrícola, 51-62,5 cm compr.; crescimento simpodial, cespitoso. Caule tipo cauloma inconspícuo, 1-foliado. Folha paralelinérvea, ca. $5 \times 1 \mathrm{~cm}$, oblonga, verde, membranácea, ápice agudo. Inflorescência apical, mais de 30 flores; pedúnculo 31,5-33 cm compr.; brácteas do pedúnculo 3-4, ca. 5,5 cm compr., lanceoladas; raque $18-29 \mathrm{~cm}$ compr.; brácteas florais 3-4 mm compr., lanceoladas. Flores monoclinas, não ressupinadas, verdes; ovário 3-4 mm compr.; sépalas ovadas, glabras, as laterais 1,7-2,5 × 0,8-0,9 mm, reflexas, coalescentes na base, a mediana ca. 1,6 $\times$ $0,5-0,7 \mathrm{~mm}$, convoluta; pétalas $1,5-2,5 \times$ ca. $0,3 \mathrm{~mm}$, convolutas, inteiras, lineares; labelo inteiro, $1,8-2,7$ $\times 0,9-1,7 \mathrm{~mm}$, calceolado, verde, carnoso, glabro, margem inteira; coluna $0,9-1,2 \times 0,4-0,7 \mathrm{~mm}$, livre, com projeção membranácea, cuculada.

Material examinado: Morro do Chapéu, BA 052, 29.I.2003, fl., F. França et al. 4056 (HUEFS).

Material adicional: BRASIL. BAHIA: Lençóis, Rio Mucugezinho, 20.XII.1984, fl., fr., B. Stannard 7308 (HUEFS, SPF).

Considerada endêmica da Bahia por Barros et al. (2010), é citada também para o estado do Rio de Janeiro por Pabst \& Dungs (1975), muito embora essa ocorrência não tenha sido confirmada por Azevedo (2009) na revisão do gênero. Ocorre em áreas de Caatinga e Cerrado (Barros et al. 2010) e em restinga no litoral leste da Bahia (Azevedo 2009). $\mathrm{Na}$ Chapada Diamantina, é encontrada em Catolés, Lençóis, Mucugê, Palmeiras e Rio de Contas. No município de Morro do Chapéu foi encontrada em floresta antropizada, com flor em janeiro.

Morfologicamente, P. leptostachya é semelhante a $P$. plantaginifolia Lindl., mas esta última tem superfície abaxial das folhas coberta por tricomas enquanto que em P. leptosthachya ela é glabra (Azevedo 2009).

47. Prescottia montana Barb. Rodr., Gen. Sp. Orchid. 1: 178. 1877.

Fig. 10g-1

Terrícola ou rupícola, $42-71,5 \mathrm{~cm}$ compr.; crescimento simpodial, cespitoso. Caule tipo cauloma inconspícuo, 1-foliado. Folha paralelinérvea, 6,5-19 $\times 1-1,3 \mathrm{~cm}$, oblonga a lanceolada, verde, cartácea a coriácea, ápice agudo. Inflorescência apical, 15-30 flores; pedúnculo 17-57 cm compr.; brácteas do pedúnculo 5, 2,6-7,5 cm compr., lanceoladas; raque $3,5-14,5 \mathrm{~cm}$ compr.; brácteas florais $6-8 \mathrm{~mm}$ compr., ovadas a lanceoladas. Flores monoclinas, não ressupinadas, amarelo-esverdeadas; ovário 3-6 mm compr.; sépalas eretas, oblongas, glabras, as laterais $3-3,5 \times 1-1,5 \mathrm{~mm}$, livres entre si, a mediana 3-3,7 × 1-1,3 mm; pétalas $2-2,2 \times 0,3-0,5 \mathrm{~mm}$, eretas, inteiras, oblongas; labelo inteiro, ca. $4 \times 2$ $\mathrm{mm}$, calceolado, verde, carnoso, glabro, margem inteira; coluna 1-2 × 1-1,2 mm, livre, com projeção membranácea, cuculada; antera $0,5 \times 0,5 \mathrm{~mm}$, sem apêndice apical; polínias 4, iguais, arredondadas.

Materiais examinados: Morro do Chapéu, Morrão, 11.XI.2001, fr., E.L. Borba 2070 (HUEFS); 8.X.2007, fl., C.A. Bastos 83 (HUEFS). 

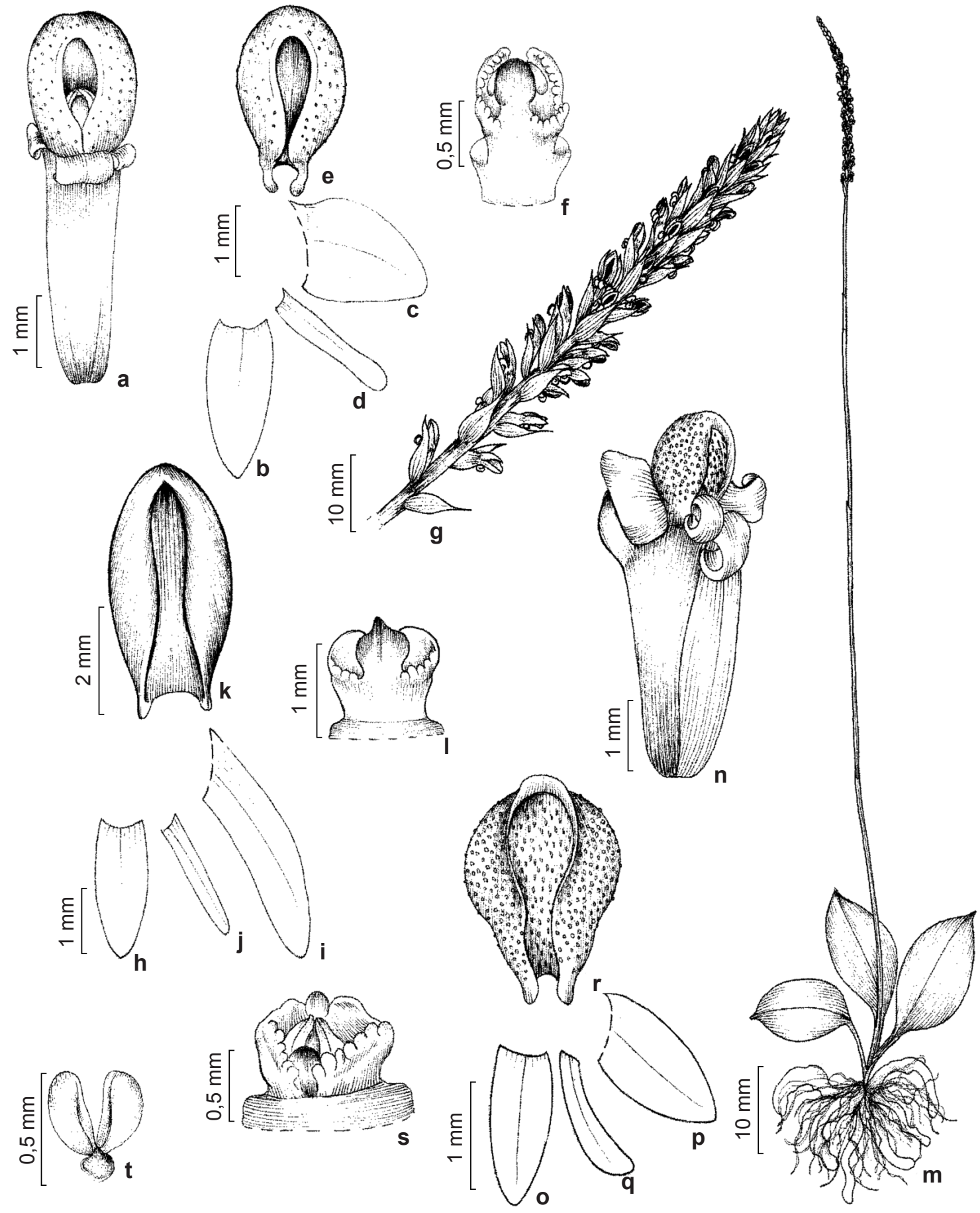

Figura 10 - a-f. Prescottia leptostachya - a. flor; b. sépala dorsal; c. sépala lateral; d. pétala; e. labelo; f. coluna em vista dorsal. g-1. Prescottia montana - g. inflorescência; $h$. sépala dorsal; i. sépala lateral; j. pétala; k. labelo; 1 . coluna em vista dorsal. $\mathrm{m}$-t. Prescottia oligantha $-\mathrm{m}$. hábito; n. flor; o. sépala dorsal; p. sépala lateral; q. pétala; r. labelo; s. coluna em vista ventral; t. polinário. (a-f França 4056; g-1 Borba 2070; m-t Melo 5046).

Figure 10 - a-f. Prescottia leptostachya - a. flower; b. dorsal sepal; c. lateral sepal; d. petal; e. lip; f. column seen from above. g-1. Prescottia montana - g. inflorescence; h. dorsal sepal; i. lateral sepal; j. petal; k. lip; 1. column seen from above. m-t. Prescottia oligantha - m. habit; n. flower; o. dorsal sepal; p. lateral sepal; q. petal; r. lip; s. column seen from beneath; t. pollinarium. (a-f França 4056; g-1 Borba 2070; m-t Melo 5046). 
Material adicional: BRASIL. MINAS GERAIS: Caldas, Serra da Pedra Branca, 4.IV.2007, fl., C. Azevedo \& $C$. van den Berg 324 (HUEFS).

Ocorre na Bahia, Goiás, Distrito Federal, Minas Gerais, Espírito Santo, São Paulo, Rio de Janeiro, Paraná, Santa Catarina e Rio Grande do Sul, em Cerrado e Mata Atlântica. Na Chapada Diamantina há registro no município de Mucugê. Em Morro do Chapéu ocorre em área de floresta e em pequena porção de terra entre as rochas de campo rupestre exposta ao sol. Floresce em outubro e novembro.

Na filogenia de Prescottia Lindl., com base em dados moleculares, realizada por Azevedo (2009), P. montana mostrou-se irmã de $P$. stachyodes Lindl. Essas espécies compartilham algumas similaridades morfológicas, como as folhas pecioladas, diferindo pelo labelo calceolado com ápice obtuso em $P$. montana que em $P$. stachyodes é agudo. No entando, morfologicamente $P$. montana é mais similar a $P$. phleoides Lindl. que tem folhas sésseis a pseudopecioladas (Azevedo 2009).

48. Prescottia oligantha (Sw.) Lindl., Gen. Sp. Orchid. Pl. 454. 1840.

Fig. $10 \mathrm{~m}-\mathrm{t}$

Terrícola, 33-35 cm compr.; crescimento simpodial cespitoso. Caule tipo cauloma inconspícuo, 2-4-foliado. Folhas com nervação reticulada, 4-5, ca. $8 \times 1,5 \mathrm{~cm}$, espiraladas, ovadas, verdes, membranácea, ápice agudo. Inflorescência apical, mais de 30 flores; pedúnculo ca. $25,5 \mathrm{~cm}$ compr.; brácteas do pedúnculo 5-6, 2,4-2,6 cm compr., lanceoladas; raque ca. $6,5 \mathrm{~cm}$ compr.; brácteas florais 2-3,3 mm compr., lanceoladas. Flores monoclinas, não ressupinadas, brancas; ovário ca. 2,5 mm compr.; sépalas revolutas, oblongas, glabrasas laterais ca. 1,5 ×0,8 mm, coalescentes na base, a mediana 1,1-1,2 ×0,5-0,6 mm; pétalas ca. $1,6 \times 0,5 \mathrm{~mm}$, revolutas, inteiras, oblongas; labelo inteiro, 1,3-1,5 × 0,8-1 mm, calceolado, branco, membranáceo, internamente piloso, margem inteira; coluna 0,5-1,4 × 0,5-1,1 mm, livre, com projeção membranácea, cuculada; antera $0,3 \times$ $0,5 \mathrm{~mm}$, sem apêndice apical.

Material examinado: Morro do Chapéu, nascente do Rio Salitre, 7.IX.2007, fl., E. Melo 5046 (HUEFS).

Material adicional: BRASIL. BAHIA: Feira de Santana, estrada para Retiro, 22.IX.1995, fl., F. França et al. 1361 (HUEFS)

Ocorre de norte a sul do Brasil, nos domínios fitogeográficos da Amazônia, Cerrado e Mata Atlântica. Na Chapada Diamantina não havia sido citada antes e no município de Morro do Chapéu, foi encontrada em mata ciliar, com flor em setembro.
49. Prosthechea moojenii (Pabst) W.E.Higgins, Phytologia 82(5): 379.1997 [1998]. Fig. 11a-h Rupícola, 16-27 cm compr; crescimento simpodial, cespitoso. Caule tipo pseudobulbo 6-10× 1,5-4,5 cm, elíptico, 2-foliado. Folhas com nervação paralela, 8-13 × 1,5-3 cm, dísticas, oblongas, verdes, carnosas, ápice obtuso a agudo. Inflorescência apical, 5-7 flores; pedúnculo 5,5-12 cm compr.; brácteas do pedúnculo 2-3, 4-5 mm compr., lanceoladas; raque 5,4-9 cm compr.; brácteas florais 2-4 mm compr., lanceoladas. Flores monoclinas, não ressupinadas, esverdeadas; pedicelo com ovário 1,2-2,2 cm compr.; sépalas eretas, lanceoladas, glabras, as laterais $1,5-1,8 \times 0,5-0,7 \mathrm{~cm}$, livres entre si, a mediana 1,6-2 $\times 0,5-0,7 \mathrm{~cm}$; pétalas $1,4-2 \times 0,5-0,7 \mathrm{~cm}$, eretas, inteiras, lanceoladas; labelo inteiro, 1,2-1,4 × 0,6-1,2 $\mathrm{cm}$, obdeltoide, branco, suavemente tracejado de vináceo, carnoso, glabro, margem inteira; coluna 7-9 $\times$ ca. $5 \mathrm{~mm}$, parcialmente adnata abaxialmente ao labelo; antera 2-2,3 × 2-3 mm, sem apêndice apical; polínias 4, iguais, ovais.

Materiais examinados: Morro do Chapéu, estrada para Bonito, 17.XI.1999, fl., E. Melo 3131 (HUEFS); Morrão, 8.X.2007, fl., C.A. Bastos 81 (HUEFS); Tabuleiro dos Tigres, 18.III.2004, fl., D.T. Cruz 2, 4 (HUEFS).

Endêmica do Brasil, ocorre na Bahia e em Minas Gerais, em Caatinga e Cerrado. Na Bahia foi citada para vários municípios da Chapada Diamantina, entre eles Abaíra, Ibicoara, Lençóis, Morro do Chapéu, Mucugê e Palmeiras. Em Morro do Chapéu, foi coletada nos afloramentos rochosos de campos rupestres. Floresce de setembro a março.

50. Rodriguezia obtusifolia Rchb.f., Bot. Zeitung (Berlin) 10: 771. 1952.

Fig. 11i-o

Epífita, 28-77 cm compr.; crescimento simpodial, escandente. Caule tipo pseudobulbo 2,5-3,7 × 0,6-1 cm, ovado, 2-3-foliado. Folhas com nervação paralela, 6-9 × 1,7-2,2 cm, espaçadas, dísticas, oblongas, verdes, coriáceas, ápice obtuso. Inflorescência lateral, 6-13 flores; pedúnculo 18,527,3 cm compr.; brácteas do pedúnculo 7-9, 0,6-1,6 cm compr., lanceoladas; raque 5,6-21,6 cm compr.; brácteas florais ca. $5 \mathrm{~mm}$ compr., lanceoladas. Flores monoclinas, ressupinadas, esbranquiçadas; pedicelo com ovário 1-2 cm compr:; sépalas eretas, lanceoladas, glabras, as laterais $1,5-1,8 \times$ ca. $0,5 \mathrm{~cm}$, coalescentes na base, a mediana $1,7-2 \times 0,4-0,6 \mathrm{~cm}$; pétalas $1,8-2$ $\times 0,6-1 \mathrm{~cm}$, eretas, inteiras, obovadas; labelo inteiro, ca. 30 × 19-20 cm, obcordato, branco, membranáceo, glabro, margem inteira; coluna 0,5-1 × 0,2-0,3 cm, livre; antera $3 \times 2 \mathrm{~mm}$, sem apêndice apical. 


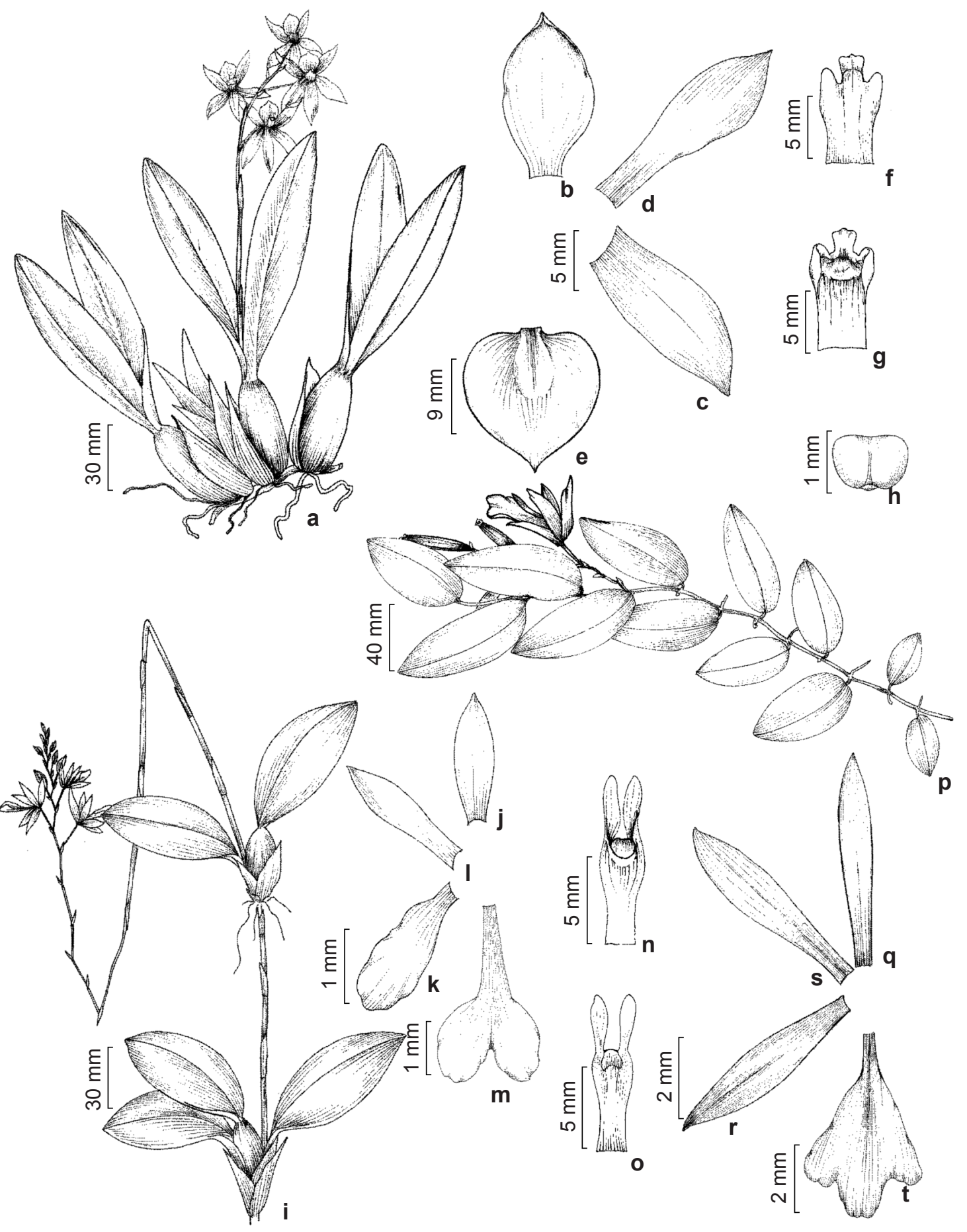

Figura 11 - a-h. Prosthechea moojenii -a. hábito; b. sépala dorsal; c. sépala lateral; d. pétala; e. labelo; f. coluna em vista dorsal; g. coluna em vista ventral; h. antera em vista dorsal. i-o. Rodriguezia obtusifolia - i. hábito; j. sépala dorsal; k. sépala lateral; 1. pétala; m. labelo; n. coluna em vista ventral; o. coluna em vista dorsal. p-t . Vanilla palmarum - p. hábito; q. sépala dorsal; r. sépala lateral; s. pétala; t. labelo explanado. (a. Cruz 2, b-h. Furlan 294; i-o. Nonato 962; p. Junqueira 199, q-t. Correia 214). Figure 11 - a-h. Prosthechea moojenii - a. habit; b. dorsal sepal; c. lateral sepal; d. petal; e. lip; f. column seen from above; g. column seen from beneath; h. anther seen from above. i-o. Rodriguezia obtusifolia - i. habit; j. dorsal sepal; k. lateral sepal; 1. petal; m. lip; n. column seen from beneath; o. column seen from above. p-t. Vanilla palmarum - p. habit; q. dorsal sepal; r. lateral sepal; s. petal; t. lip flattened out. (a. Cruz 2, b-h. Furlan 294; i-o. Nonato 962; p. Junqueira 199, q-t. Correia 214). 
Materiais examinados: Morro do Chapéu, Morrão, 4.VIII.2001, fl., F.R. Nonato et al. 962 (HUEFS); 20.VIII.2002, fl., E.C. Smidt \& F.R. Nonato 360 (HUEFS). Material adicional: BRASIL. BAHIA: Abaíra, estrada Piatã - Abaíra, 20.VII.1992, fl., W. Ganev 688 (HUEFS).

É endêmica do Brasil, de Mata Atlântica, com ocorrência registrada para a Bahia, Espírito Santo, São Paulo e Rio de Janeiro. Ocorre na Chapada Diamantina em Catolés. No Morro do Chapéu foi coletada em mata de grotão sobre tronco de árvore. Floresce em agosto.

A presença de rizomas longos com pseudobulbos espaçados é bem característico em $R$. obtusifolia. Esse espaçamento é de 10 a $15 \mathrm{~cm}$ entre psudobulbos e não ocorre de modo tão evidente em nenhuma das demais espécies da área.

51. Sobralia sessilis Lindl., Edwards's Bot. Reg. 27: Misc. 3. 1841.

Terrícola, ca. 35,5-69,5 cm compr.; crescimento simpodial, cespitoso. Caule tipo cauloma 31-61 $\times 0,3-0,4 \mathrm{~cm}$, cilíndrico, 14-16-foliado. Folhas com nervação paralela, $10,5-21,5 \times 3-7,5 \mathrm{~cm}$, dísticas, lanceoladas, verdes, membranáceas, ápice agudo. Inflorescência apical, 1-2 flores; pedúnculo inconspícuo; brácteas do pedúnculo $2-3,3,3-4,1$ cm compr., lanceoladas; raque inconspícua; brácteas florais $2,3-3 \mathrm{~cm}$ compr., lanceoladas. Flores monoclinas, ressupinadas, róseas; pedicelo com ovário 2-3 cm compr.; sépalas revolutas, lanceoladas, glabras, as laterais $3,3-5,5 \times 0,8-1 \mathrm{~cm}$, livres entre si, a mediana 3,4-5 × 0,8-1 cm; pétalas 3,2-4 × 0,8-1,2 $\mathrm{cm}$, revolutas, inteiras, lanceoladas; labelo inteiro, 3,2-4,8 × 1-1,6 cm, campanulado, rosa-escuro com o centro róseo-esbranquiçado, membranáceo, glabro, margem inteira; coluna 2-2,8 $\times 0,3-0,4 \mathrm{~cm}$, livre, com projeções laterais, orbiculares; antera 3,1 $\times 2,5$ $\mathrm{mm}$, sem apêndice apical.

Materiais examinados: Morro do Chapéu, Cachoeira do Ferro Doido, 6.V.2007, fl., C.A. Bastos 9 (HUEFS); Cachoeira Pedro Bravo, 5.III.2008, veg., C.A. Bastos 157 (HUEFS); estrada para Mundo Novo, 2.III.1977, fl., R.M. Harley 19238, 19239 (CEPEC, SPF); Gruta da Boa Esperança, 14.XI.2008, fr., C.A. Bastos \& J. B. Pinto 279 (HUEFS).

Endêmica do Brasil, ocorre nos domínios fitogeográficos da Amazônia, Caatinga, Cerrado e Mata Atlântica, nos estados de Roraima, Amapá, Pará, Amazonas, Acre, Maranhão, Bahia e Minas Gerais. Na Chapada Diamantina foi citada para Lençóis, Morro do Chapéu, Mucugê e Palmeiras. Em Morro do Chapéu, foi coletada em solo arenoso de campo rupestre e floresta úmida. Floresce entre novembro e maio.
Sobralia decora Bateman foi listado como nome correto para $S$. sessilis por Govaerts et al. (2006), pois estes autores consideram os dois nomes sinônimos. No entanto, preferimos acatar a circunscrição de McVaugh (1985), que considera $S$. sessilis uma espécie distinta de $S$. decora, sendo $S$. sessilis o nome correto a ser aplicado aos materiais sul-americanos.

52. Trichocentrum cebolleta (Jacq.) M.W. Chase \& N.H. Williams, Lindleyana 16(2): 137. 2001.

Epífita, 0,4-1 m compr.; crescimento simpodial, subcespitoso. Caule tipo pseudobulbo 0,7-1,7 × 0,4-0,6 cm, cilíndrico, 1-foliado. Folhas com nervação paralela, $16,5-51,5 \times 0,3-0,4 \mathrm{~cm}$, isoladas, cilíndricas, verdes pintalgadas de vinho, carnosas, ápice agudo. Inflorescência lateral, 9-20 flores; pedúnculo 29-87 cm compr.; brácteas do pedúnculo 6-8, 0,6-1,6 cm compr., oblongas; raque $16-31 \mathrm{~cm}$ compr.; brácteas florais $3-0,6 \mathrm{~cm}$ compr., lanceoladas. Flores monoclinas, ressupinadas, amarelas com máculas castanho-avermelhadas; pedicelo com ovário ca. $2 \mathrm{~cm}$ compr.; sépalas reflexas, espatuladas, glabras, as laterais $0,8-1 \times$ $0,4-0,5 \mathrm{~cm}$, coalescentes na base, a mediana $0,8-1 \times$ ca. $0,5 \mathrm{~cm}$; pétalas $8-9 \times 5-6 \mathrm{~mm}$, reflexas, inteiras, oblongas; labelo trilobado, amarelo, membranáceo, glabro, margem inteira, com calosidade orbicular enrrugada, base com projeções laterais denticuladas e central linear, glabra, lobos laterais ca. $8 \times 4-5 \mathrm{~mm}$, obovados, explanados, lobo mediano ca. $1 \times 1-1,8$ $\mathrm{cm}$, reniforme; coluna 3-4× ca. $2 \mathrm{~mm}$, livre, com projeções latero-apicais orbiculares, latero-basais triangulares e dorsa triangular; antera 2,5 × 1,5 mm, sem apêndice apical; polínias 2, iguais, obovais.

Material examinado: Morro do Chapéu, Cidade das Pedras, 9.XII.2006, veg., M.L. Guedes et al. 12940 (ALCB). Materiais adicionais: BRASIL, BAHIA: Cachoeira, Vale dos rios Paraguaçu e Jacuípe, VIII.1980, fl., Grupo Pedra do Cavalo 516 (HUEFS); Feira de Santana, Fazenda Chapada, 11.X.2007, fl., E. Melo et al. 5156 (HUEFS).

Barros et al. (2010) citaram essa espécie como Cohniella cebolleta (Jacq.) Christenson nos estados de Roraima, Pará, Amazonas, Tocantins, Acre, Rondônia, Maranhão, Piauí, Pernambuco, Bahia, Mato Grosso, Goiás, Distrito Federal, Mato Grosso do Sul, Minas Gerais e Espírito Santo. Adicionalmente foi registrada para o Ceará (Freitas et al. 2011). Ocorre em vegetação amazônica, Cerrado e Mata Atlântica. Na Chapada Diamantina é citada como Oncidium cebolleta (Jacq.) Sw. nos municípios de Palmeiras, Rio de Contas e Rio do 
Pires (Toscano de Brito \& Cribb 2005). Em Morro do Chapéu ocorre em área de caatinga sobre tronco de árvores, florindo em dezembro.

Essa espécie foi originalmente descrita por Jacquin dentro do gênero Epidendrum L., sendo tranferida para Oncidium por Swartz em seguida. Anos depois, o gênero Cohniella Pfitz. foi restabelecido para as espécies de folhas cilíndricas, incluindo o então Oncidium cebolleta (Christenson 1999). Em 2001, a partir da análise de DNA dessa e de outras espécies afins, $C$. cebolleta foi incluída no gênero Trichocentrum Poepp. \& Endl. (Williams et al. 2001). Alguns autores dividem o grupo em unidades menores separando Trichocentrum, Lophiaris Raf. e Cohniella Pfitzer (Braem 1993; Christenson 1999). No presente trabalho, preferimos as definições amplas de gêneros, seguindo a circunscrição de Williams et al. (2001) que foram incorporadas ao Kew Monocot Checklist (Govaerts et al. 2006).

53. Vanilla palmarum (Salzm. ex Lindl.) Lindl., Gen. Sp. Orchid. Pl. 436. $1840 . \quad$ Fig. 11p-t

Epífita, 0,7-1,5 m compr.; crescimento monopodial, reptante. Caule tipo cauloma 60-150 $\times 0,3-0,4 \mathrm{~cm}$, cilíndrico, multifoliado. Folhas com nervação paralela, $8-11,5 \times 2,4-3,5 \mathrm{~cm}$, espiraladas, ovadas, verdes, carnosas, ápice agudo. Inflorescência axilar, 7-12 flores; pedúnculo inconspícuo; raque 3,4-7 cm compr.; brácteas florais 5-6 mm compr., ovadas. Flores monoclinas, ressupinadas, amarelo-esverdeadas; pedicelo com ovário $1-1,3 \mathrm{~cm}$ compr.; sépalas lanceoladas, glabras, as laterais ca. $5,4 \times 1 \mathrm{~cm}$, livres entre si, a mediana ca. $4,8 \times 0,8 \mathrm{~cm}$; pétalas ca. $5 \times 1,8 \mathrm{~cm}$, inteiras, lanceoladas; labelo inteiro, ca. $5 \times 3 \mathrm{~cm}$, trífido, branco-amarelado, membranáceo, glabro, margem inteira; coluna ca. $3 \times 0,2 \mathrm{~cm}$, livre.

Materiais examinados: Morro do Chapéu, estrada para Buraco do Possidônio, 7.IV.2008, fr., C.A. Bastos \& C. van den Berg 175 (HUEFS); BA 052, 1.V.2003, fl., fr., M.E.R. Junqueira et al. 199 (HUEFS); estrada para Jacobina, 23.VII.2008, fr., C.A Bastos \& J.B. Pinto 245 (HUEFS); Miraserra, 16.VI.2008, fr., C.A. Bastos 205 (HUEFS); Morrão, 9.X.2007, veg., C.A. Bastos 96 (HUEFS).

Materiais adicionais: BRASIL. BAHIA: Banzae, Baixa do Juá, 28.XI.2002, fl., C. Correia et al. 214 (HUEFS).

No Brasil ocorre em Roraima, Pará, Amazonas, Maranhão, Pernambuco, Bahia, Alagoas, Mato Grosso e Mato Grosso do Sul, nos domínios fitogeográficos da Amazônia, Caatinga, Cerrado e Mata Atlântica. Adicionalmente há registro para o Ceará (Freitas et al. 2011) e para o Paraná (Angely
1965). É citada para a Chapada Diamantina, mas sem localidade identificada (van den Berg \& Azevedo 2005; Toscano de Brito \& Cribb 2005). No município de Morro do Chapéu é amplamente encontrada em caatinga sobre Syagrus coronata, com flor de outubro a julho.

\section{Agradecimentos}

Ao Programa de Pós-Graduação em Botânica da UEFS o custeio das visitas aos herbários do Sul e Sudeste e confecção das ilustrações. A APNE (Associação Plantas do Nordeste) o auxílio na visita ao herbário CEPEC e expedições de campo. À FAPESB e à CAPES a concessão da bolsa de mestrado, em momentos distintos, à primeira autora. Ao Ir. Delmar (grande conhecedor da região de Morro do Chapéu) a orientação no trabalho de coleta, a Antonio L. Toscano de Brito o auxílio na identificação das espécies, a banca examinadora do mestrado pelas sugestões, a Carla de Lima as ilustrações e a Leilton Damascena o mapa. O segundo autor foi apoiado pelo CNPq (Bolsa PQ-1D).

\section{Referências}

Angely, J. 1965. Flora analítica do Paraná. Universidade de São Paulo, São Paulo. Pp. 232-287.

Azevedo, C.O. 2009. Filogenia e revisão do gênero Prescottia Lindl. (Orchidaceae - Orchidoideae). Tese de Doutorado. Universidade Estadual de Feira de Santana, Feira de Santana. Pp. 170-205.

Azevedo, C.O. \& van den Berg, C. 2007a. A família Orchidaceae no Parque Municipal de Mucugê, Bahia, Brasil. Hoehnea 34: 1-47.

Azevedo, C.O. \& van den Berg, C. 2007b. Análise comparativa de áreas de campo rupestre da Cadeia do Espinhaço (Bahia e Minas Gerais, Brasil) baseada em espécies de Orchidaceae. Sitientibus série Ciências Biológicas 7: 199-210.

Barbero, A.P.P. 2007. Flora da Serra do Cipó (Minas Gerais, Brasil): Orchidaceae - Subtribo Laeliinae. Dissertação de Mestrado. Secretaria do Meio Ambiente, São Paulo. 92p.

Barbosa, M. A. 1995. Clima. In: Rocha, A.J.D. \& Costa, I.V.G. (org.). Projeto mapas municipais: município de Morro do chapéu (BA). Ministério de Minas e Energia, Morro do Chapéu. Pp. 39-52.

Barbosa Rodrigues, J. 1877-1882. Genera et Species Orchidearum Novarum I, II, III. In: Sprunger, S.; Cribb, P. \& Toscano de Brito, A.L.V. 1996. Iconographie des orchidées du Brésil. Vol. 1, 2. Reinhardt, Basle. 540p.

Barros, F. \& Pinheiro, F. 2004. Flora de Grão-Mogol, Minas Gerais: Orchidaceae. Boletim de Botânica da Universidade de São Paulo 22: 361-383. 
Barros, F. 1987. Orchidaceae In: Giulietti, A.M.; Menezes, N.L.; Pirani, J.R.; Meguro, M. \& Wanderley, M.G.L. 1987. Flora da Serra do Cipó, Minas Gerais: caracterização e lista de espécies. Boletim de Botânica da Universidade de São Paulo 9: 1-151.

Barros, F. 1994. Novas combinações, novas ocorrências e notas sobre espécies pouco conhecidas para as orquídeas do Brasil. Acta Botanica Brasilica 8: 11-17.

Barros, F.; Vinhos, F.; Rodrigues, V.T.; Barberena, F.F. V.A.; Fraga, C.N. 2010. Orchidaceae. In: Forzza, R.C. et al. (orgs.). Catálogo de plantas e fungos do Brasil. Vol. 2. Instituto de Pesquisas Jardim Botânico do Rio de Janeiro, Rio de Janeiro. Pp. 1344-1426.

Bastos, C.A. 2009. A família Orchidaceae no município de Morro do Chapéu, Bahia, Brasil. Dissertação de Mestrado. Universidade Estadual de Feira de Santana, Feira de Santana. 110p.

Bastos, C.A. \& van den Berg, C. no prelo. Flora da Bahia: Catasetum L.C.Rich. ex Kunth (Orchidaceae). Sitientibus série Ciências Biológicas.

Batista, J.A.N. \& Bianchetti, L.B. 2003. Lista atualizada das Orchidaceae do Distrito Federal. Acta Botanica Brasilica 17: 183-201.

Batista, J.A.N.; Silva, J.B.F. \& Bianchetti, L.B. 2008. The genus Habenaria (Orchidaceae) in the Brazilian Amazon. Revista Brasileira de Botânica 31: 105-134.

Bicalho, H.D. 1960. Contribuição à sistemática do gênero Catasetum L.C. Rich. (Orchidaceae). Tese de Doutorado. Escola Superior de Agricultura Luis de Queiroz, Piracicaba.

Borba, E.B. 2003. Novas combinações em Acianthera (Pleurothallis s. l.; Orchidaceae: Pleurothallidine) ocorrentes nos campos rupestres brasileiros. Sitientibus, Série Ciências Biológicas 3: 22-25.

Borba, E.L. \& Semir, J. 1998. Bulbophyllum involutum Borba, Semir \& F. Barros (Orchidaceae), a new species from the Brazilian "Campos rupestres". Novon 8: 225-229.

Borba, E.L.; Felix, J.M.; Semir, J. \& Sqlferini, V.N. 2000. Pleurothallis fabiobarrosii, a new Brazilian species: morphological and genetic data with notes on the taxonomy of Brazilian rupicolous Pleurothallis. Lindleyana 15: 2-9.

Borba, E.L.; Shepherd, G.J.; van den Berg, C. \& Semir, J. 2002. Floral and vegetative morphometrics of five Pleurothallis (Orchidaceae) species: correlation with taxonomy, phylogeny, genetic variability and pollination systems. Annals of Botany 90: 219-230.

Braem G.J. 1993. Studies in the Oncidiinae, discussion of some taxonomic problems with description of Gudrunia Braem, gen. nov., and the reinstatement of the genus Lophiaris Rafinesque. Schlecteriana 4: 8-29.

Braem, G.J. 1995. Cattleya $\times$ tenuata Castro \& Campacci. Orchis 99: 30-31 apud Toscano de Brito, A.L.V. \&
Cribb, P. 2005. Orquídeas da Chapada Diamantina. Nova Fronteira, Rio de Janeiro. 399p.

Bummitt, R.K. \& Powell, C.E. (eds.). 1992. Authors of plant names. Kew, Richmod. 732p.

Buzatto, C.R. \& Machado, M.C. 2011. Capanemia Barb. Rodr. (Orchidaceae: Oncidiinae), a new record from Bahia state, Brazil. Acta Botanica Brasilica 25: 249-251.

Buzatto, C.R.; Freitas, E.M.; Silva, A.P.M. \& Lima, L.F.P. 2007. Levantamento florístico das Orchidaceae ocorrentes na Fazenda São Maximiano, Município de Guaíba, Rio Grande do Sul. Revista Brasileira de Biociências 5: 19-25.

Buzatto, C.R.; Singer, R. B. \& van den Berg, C. 2010. O gênero Capanemia Barb. Rodr. (Oncidiinae: Orchidaceae) na Região Sul do Brasil. Revista Brasileira de Biociências 8: 309-323.

Castro, V.P. \& Campacci, M.A. 2006. Icones Orchidacearum Brasiliensis. Vol. 1. Coordenadoria das Associações Orquidófilas do Brasil, São Bernardo do Campo. 200p.

Cerqueira, O.C.; Funch, L.S. \& Borba, E.L. 2008. Fenologia de Syngonanthus mucugensis Giul. subsp. mucugensis e $S$. curralensis Moldenke (Eriocaulaceae), nos municípios de Mucugê e Morro do Chapéu, Chapada Diamantina, BA, Brasil. Acta Botanica Brasilica 22: 962-969.

Chase, M.W.; Williams, N.H.; Faria, A.D.; Neubig, K.M.; Amaral, M.C.E. \& Whitten, W.M. 2009. Floral convergence in Oncidiinae (Cymbidieae; Orchidaceae): an expanded concept of Gomesa and a new genus Nohawilliamsia. Annals of Botany 104: 387-402.

Christenson, E.A. 1999. The return of Cohniella (Orchidaceae: Oncidiinae). Lindleyana 14: 176-177.

Cogniaux, A. 1893-1896. Orchidaceae. In: Martius, C.F.P. \& Eichler, A.G. (eds.). Flora brasiliensis. Frid. Fleischer, Lipsiae. Vol. 3, pars. 4, pp. 1-672.

Cogniaux, A. 1898-1902. Orchidaceae. In: Martius, C. F. P. \& Eichler, A. G. (eds.). Flora brasiliensis. Frid. Fleischer, Lipsiae. Vol. 3, pars. 5, pp. 1-664.

Cogniaux, A. 1904-1906. Orchidaceae. In: Martius, C.F.P. \& Eichler, A.G. (eds.). Flora brasiliensis. Frid. Fleischer, Lipsiae. Vol. 3, pars. 6, pp. 1-604.

Colaço, M.A.S.; Fonseca, R.B.S.; Lambert, S.M.; Costa, C.B.N.; Santos, C.G.M. \& Borba, E.L. 2006. Biologia reprodutiva de Melocactus glaucescens Buining \& Brederoo e M. paucispinus G. Heimen \& R. Paul (Cactaceae), na Chapada Diamantina, Nordeste do Brasil. Revista Brasileira de Botânica 29: 239-249.

Conceição, A.A. \& Giulietti, A.M. 2002. Composição florística e aspectos estruturais de campo rupestre em dois platôs do Morro do Pai Inácio, Chapada Diamantina, Bahia, Brasil. Hoehnea 29: 37-48.

Conceição, A.A. \& Pirani, J.B. 2005. Delimitação de habitats em campos rupestres na Chapada 
Diamantina, Bahia: substratos, composição florística e aspectos estruturais. Boletim de Botânica 23: 85-111.

Conceição, A.A. \& Pirani, J.R. 2007. Diversidade em quatro áreas de campos rupestres na Chapada Diamantina, Bahia, Brasil: espécies distintas, mas riquezas similares. Rodriguésia 58: 193-206.

Conceição, A.A.; Rapini, A.; Pirani, J.R.; Giulietti, A.M.; Harley, R.M.; Silva, T.R.S.; Santos, A.K. A.; Correia, C.; Andrade, I.M.; Costa, J.A.S.; Souza, L.R.S.; Andrade, M.J.G.; Funch, R.R.; Freitas, T.A.; Freitas, A.M.M. \& Oliveira, A.A. 2005. Campos rupestres In: Juncá, F.A.; Funch, L \& Rocha, W. (orgs.). Biodiversidade e conservação da Chapada Diamantina. Ministério do Meio Ambiente, Brasília. Pp. 153-180.

Conceição, A.A.; Giulietti, A.M. \& Meirelles, S.T. 2007. Ilhas de vegetação em afloramentos de quartzito-arenito no Morro do Pai Inácio, Chapada Diamantina, Bahia, Brasil. Acta Botanica Brasilica 21: 335-347.

Cruz, D.T.; Borba, E.L. \& van den Berg, C. 2003. O gênero Cattleya Lindl. (Orchidaceae) no estado da Bahia, Brasil. Sitientibus série Ciências Biológicas 3: 26-34

Cunha, M.F.B. \& Forzza, R.C. 2007. Orchidaceae no Parque Natural Municipal da Prainha, RJ, Brasil. Acta Botanica Brasilica 21: 383-400.

Dittrich, V.A.O.; Kozera, C. \& Menezes-Silva, S. 1999. Levantamento florístico dos epífitos vasculares do Parque Barigui, Curitiba, Paraná, Brasil. Iheringia 52: 11-21.

Docha Neto, A.; Baptista, D.H. \& Campacci, M.A. 2006. Novos gêneros baseados nos Oncidium brasileiros. Coletânea de Orquídeas Brasileiras 3: 65-95.

Dressler, R.L. 1993. Phylogeny and classification of the orchid family. Cambridge University Press, Melbourne. 314p.

Dressler, R.L. 2005. How many orchid species? Selbyana 26: $155-158$.

Dunsterville, G.C.K. \& Garey, L.A. 1961. Venezuelan Orchids illustrated. Vol. 2. Andre Deutsch Limited, London. 360p.

Echternacht, L.; Trovó, M.; Oliveira, C.T. \& Pirani, J.R. 2011. Areas of endemism in the Espinhaço Range in Minas Gerais, Brazil. Flora 50508: 1-10.

Fernandes, M.F.; Queiroz, L.P.; Haroldo, F.; Nascimento, F. \& Machado, R.F. 2010. Levantamento florístico das florestas de altitude do município de Morro do Chapéu, Bahia. Anais do XIV Seminário de Iniciação Científica da Universidade Estadual de Feira de Santana, Feira de Santana. Pp. 199-202.

Ferreira, A.W.C. \& Pansarin, M.I.S.L. 2010. Orchidaceae na região central de São Paulo, Brasil. Rodriguésia 61: 243-259.

Fowlie, J.A. 1977. The brazilian bifoliate Cattleyas and their color varieties. Azul Quinta Press, Pomona apud Toscano de Brito, A.L.V. \& Cribb, P. 2005.
Orquídeas da Chapada Diamantina. Nova Fronteira, Rio de Janeiro. 399p.

Freitas, R.C.A.; Santos, M.L.G \& Matias, L.Q. 2011. Checklist das monocotiledôneas do Ceará, Brasil. Revista Caatinga 24: 75-84.

Giulietti, A.M. \& Pirani, J.R. 1988. Patterns of geographic distribution of some plant species from the Espinhaço range, Minas Gerais and Bahia, Brazil. In: Vazzoline, P.E. \& Heyer, W.R. (eds.). Proceedings of a worshop on neotropical distributions patterns. Academia Brasileira de Ciências, Rio de Janeiro. Pp. 39-68.

Govaerts, R.; Dransfield, J.; Zona, S.F.; Hodel, D.R. \& Henderson, A. 2006. World checklist of Orchidaceae. The Board of Trustees of the Royal Botanic Gardens, Kew. Disponível em <http://www. kew.org/wcsp/>. Acesso em 20 Mai 2011.

Guedes, M.L.S. \& Orge, M.D. (eds.). 1998. Checklist das espécies vasculares do Morro do Pai Inácio (Palmeiras) e Serra da Chapadinha (Lençóis), Chapada Diamantina, Bahia, Brasil. Universidade Federal da Bahia, Salvador.

Harley, R.M. 1988. Evolution and distribution of Eriope (Labiate) and its relatives in Brazil. In: Vazzolini, P.E. \& Heyer, W.R. (eds.). Proceedings of a worshop on neotropical distributions patterns. Academia Brasileira de Ciências, Rio de Janeiro. Pp. 71-120.

Harley, R.M. 1995. Introduction. In: Stannard, B.L. (ed.). Flora of the Pico das Almas, Chapada Diamantina, Bahia, Brasil. Kew, Richmod. Pp. 43-76.

Harley, R.M. 2005. Introdução. In: Toscano de Brito, A.L.V. \& Cribb, P.J. Orquídeas da Chapada Diamantina. Nova Fronteira, Rio de Janeiro. Pp. 23-40.

Harley, R.M. \& Mayo, S.J. 1980. Towards a checklist of the flora of Bahia. Kew, Richmod. Pp. 153-158.

Harley, R.M. \& Simmons, N.A. 1986. Florula of Mucugê, Chapada Diamantina, Bahia, Brazil. Kew, Richmod. Pp. 160-165.

Harris, J.G. \& Harris, M.W. 1994. Plant identification terminology: an illustrated glossary. Spring Lake, Payson. 188p.

Hoehne, F.C. 1942. Orchidaceae. In: Hoehne, F.C. (ed.). Flora brasílica. Secretaria da Agricultura, Indústria e Comércio de São Paulo 12: 1-218.

Holmgren, P.K.; Holmgren, N.H. \& Barnett, L.C. (eds.). 1990. Index Herbariorum. Part I: The herbaria of the world (Regnum Vegetabile 120). New York Botanical Garden, New York. 693p.

Izabel, T.S.S.; Santos, D.S.; Almeida, D.A.C. \& Gusmão, L.F.P. 2011. Fungos conidiais do bioma Caatinga II. Novos registros para o continente americano, Neotrópico, América do Sul e Brasil. Rodriguésia 62: 1-12.

Junqueira, M.E.R. \& Simão-Bianchini, R. 2006. O gênero Evolvulus L. (Convolvulaceae) no município de Morro do Chapéu, BA, Brasil. Acta Botanica Brasilica 20: 157-172. 
Koehler, S. \& Amaral, M.C.E. 2004. A taxonomic study of the South American genus Bifrenaria Lindl. (Orchidaceae). Brittonia 56: 314-345.

Lima, L.C.L.; Silva, F.H.M. \& Santos, F.A.R. 2008. Palinologia de espécies de Mimosa L. (Leguminosae - Mimosoideae) do Semi-Árido brasileiro. Acta Botanica Brasilica 22: 794-805.

Lobão, J.S.B. 2006. Análise socioambiental no Município de Morro do Chapéu-BA baseada em geotecnologias. Dissertação de Mestrado. Universidade Federal da Bahia, Salvador. 350p.

McVaugh, R. 1985. Flora Novo-Galiciana: a descriptive account of the vascular plants of western Mexico. Vol. 16: Orchidaceae. The University of Michigan Press, Ann Arbor. 363p.

Menezes, L.C. 2000. Genus Cyrtopodium: espécies brasileiras. IBAMA, Brasília. 208p.

Menini, L; Almeida, V.R. \& Forzza, R.C. 2004. A família Orchidaceae na Reserva Biológica da Represa do Grama, Descoberto, Minas Gerais, Brasil. Rodriguésia 55: 137-156.

Menini Neto, L.; Alves, R.J.V.; Barros, F. \& Forzza, R.C. 2007. Orchidaceae do Parque Estadual de Ibitipoca, MG, Brasil. Acta Botanica Brasilica 21: 687-696.

Meyer, S.T. \& Franceschinelli, E.V. 2010. Estudo florístico de plantas vasculares associadas às áreas úmidas na Cadeia do Espinhaço (MG), Brasil. Revista Brasileira de Botânica 33: 677-691.

Monteiro, S.H.N. 2007. Revisão taxonômica e filogenia do gênero Galeandra Lindl. (Orchidaceae: Catasetinae). Tese de Doutorado. Universidade Estadual de Feira de Santana, Feira de Santana. 178p.

Pabst, G.F.J. 1972a. El género Capanemia Barb.Rodr. Orquideologia 7: 215-242.

Pabst, G.F.J. 1972b. Estudos no gênero Oncidium Sw. (Orchidceae)-IV. Bradea 1: 137-143.

Pabst, G.F.J. \& Dungs, F. 1975. Orchidaceae Brasiliensis. Vol. 1. Brucke-Verlag Kurt Schmersow, Hildesheim. 408p.

Pabst, G.F.J. \& Dungs, F. 1977. Orchidaceae Brasiliensis. Vol. 2. Brucke-Verlag Kurt Schmersow, Hildesheim. $418 \mathrm{p}$.

Pansarin, E.R. \& Amaral, M.C.E. 2006. Biologia reprodutiva e polinização de duas espécies de Polystachya Hook. no Sudeste do Brasil: evidência de pseudocleistogamia em Polystachyeae (Orchidaceae). Revista Brasileira de Botânica 29: 423-432.

Pansarin, E.R. \& Pansarin, L.M. 2008. A família Orchidaceae na Serra do Japi, São Paulo, Brasil. Rodriguésia 59: 99-111.

Pedroso de Moraes, C.; Domingues, E.; Prezzi, L.E.; Souza Leal, T.; Zambon, R.I.; Brescansin, R.L. \& Ramos, P.A.B. 2010. Florística e fitossociologia da família Orchidaceae no Centro de Educação Ambiental "Francisco Mendes", município de Mogi Guaçu, SP, Brasil. Scientia Plena 6: 1-5.
Peron, M.V. 1989. Listagem preliminar da flora fanerogâmica dos campos rupestres do Parque Estadual do Itacalomi - Ouro Preto / Mariana, MG. Rodriguésia 67: 63-69.

Pridgeon, A.M.; Cribb, P.J.; Chase, M.W. \& Rasmussen, F.N. 1999. Genera Orchidacearum. 1. Oxford University Press, New York. 298p.

Pridgeon, A.M.; Cribb, P.J.; Chase, M.W. \& Rasmussen, F.N. 2001. Genera Orchidacearum. 2. Oxford University Press, New York, 464p.

Pridgeon, A. M.; Cribb, P. J.; Chase, M. W. \& Ramussen, F. N. 2003. Genera Orchidacearum. 3. Orchidoideae (Part Two) - Vanilloideae. Oxford University Press, New York

Pridgeon, A. M.; Cribb, P. J.; Chase, M.C. \& Rasmussen, F.N. 2006. Epidendroideae (Part One). Genera Orchidacearum. 4. Oxford University Press, New York. 672p.

Ramos, C.O.C.; Borba, E.L. \& Funch, L.S. 2005. Pollination in Brazilian Syngonanthus (Eriocaulaceae) species: Evidence for entomophily instead of anemophily. Annals of Botany 96: 387-397.

Rapini, A.; Mello-Silva, R. \& Kawasaki, M.L. 2002. Richness and endemism in Asclepiadoideae (Apocynaceae) from the Espinhaço range of Minas Gerais, Brazil - a conservationist view. Biodiversity and Conservation 11: 1733-1746.

Rapini, A.; Ribeiro, P.L.; Lambert, S. \& Pirani, J.R. 2008. A flora dos campos rupestres da Cadeia do Espinhaço. Megadiversidade 4: 16-24.

Ribeiro, P.L.; Borba, E.L. \& Toscano de Brito, A.L.V. 2005. O gênero Bulbophyllum Thours (Orchidaceae) na Chapada Diamantina, Bahia, Brasil. Revista Brasileira de Botânica 28: 423-439.

Ribeiro, P.L.; Borba, E.L.; Smidt, E.C.; Lambert, S.M.; Selbach-Schnadelbach, A. \& van den Berg, C. 2007. Genetic and Morphological variation in the Bulbophyllum exaltatum (Orchidaceae) complex occurring in the brazilian "campos rupestres": implications for taxonomy and biogeography. Lankesteriana 7: 342-346.

Rocha, A.J.D. \& Costa, I.V.G. 1995. Introdução. In: Rocha, A.J.D. \& Costa, I.V.G. (org.). Projeto mapas municipais: município de Morro do chapéu (BA). Ministério de Minas e Energia, Morro do Chapéu. Pp. 10-12.

Rocha, F.S. \& Waechter, J.L. 2006. Sinopse das Orchidaceae terrestres ocorrentes no litoral norte do Rio Grande do Sul, Brasil. Acta Botanica Brasilica 20: 71-86.

Romero-González, G.A.; Batista, J.A.N. \& Bianchetti, L.B. 2008. A synopsis of the genus Cyrtopodium (Catasetinae: Orchidaceae). Harvard Papers in Botany 13: 189-206.

Schuster, H.; Pedroso de Moraes, C.; Souza-Leal, T.; Callegari-Correia, E.; Prezzi, L.E., Domingues, E. \& Canassa, F. 2010. Diversidade de Orchidaceae 
da fazenda Cantagalo, município de Mogi-Mirim, São Paulo. Revista Brasileira de Biociências 8: 242-245

Silva, S.B. 1995. Vegetação. In: Rocha, A.J.D. \& Costa, I.V.G. (org.). projeto mapas municipais: município de Morro do Chapéu (BA). Ministério de Minas e Energia, Morro do Chapéu. Pp. 113-121.

Smidt, E.C. 2003. A subtribo Spiranthinae Lindl. (Orchidaceae: Orchidioideae) na Chapada Diamantina, Bahia, Brasil. Dissertação de Mestrado. Universidade Estadual de Feira de Santana, Feira de Santana. 113p.

Smidt, E.C. 2007. Filogenia e revisão taxonômica de Bulbophyllum Thours (Orchidaceae) ocorrentes no Neotrópico. Tese de Doutorado. Universidade Estadual de Feira de Santana, Feira de Santana. 346p.

Stannard, B.L. (ed.). 1995. Flora of the Pico das Almas: Chapada Diamantina, Bahia, Brasil. Royal Botanic Gardens, Kew. 853p.

Stearn, W.T. 2004. Botanical Latin. 4 ed. Timer Press, Portland. 546p.

Toscano de Brito, A.L.V. 1995. Orchidaceae. In: Stannard, B.L. (ed.). Flora of the Pico das Almas: Chapada Diamantina, Bahia, Brazil. Kew, Richmod. Pp. 725-767.

Toscano de Brito, A.L.V. 1998. Orchidaceae. In: Guedes, M.L.S. \& Orge, M.D. (orgs.). Checklist das espécies vasculares do Morro do Pai Inácio (Palmeiras) e Serra da Chapadinha (Lençóis),
Chapada Diamantina, Bahia, Brasil. Universidade Federal da Bahia, Salvador. Pp. 33, 53-54.

Toscano de Brito, A.L.V. \& Cribb, P. 2005. Orquídeas da Chapada Diamantina. Nova Fronteira, Rio de Janeiro. 399p.

Toscano de Brito, A.L.V. \& Queiroz, L.P. 2003. Orchidaceae. In: Zappi, D.C.; Lucas, E.; Stannard, B.L.; Lughada, E.N.; Pirani, J.R.; Queiroz, L.P.; Atkins, S.; Hind, D.J.N.; Giulietti, A.M.; Harley, R.M.; Carvalho, A.M. Lista das plantas de Catolés, Chapada Diamantina, Bahia, Brasil. Boletim de Botânica 21: 396-397.

van den Berg, C. \& Azevedo, C.O. 2005. Orquídeas. In: Juncá, F.; Funch, L.S. \& Rocha, W. Biodiversidade e Conservação da Chapada Diamantina. Ministério do Meio Ambiente, Brasília. Pp. 195-208.

Williams, N.H.; Chase, M.W.; Fulcher, T.; Whitten, W.M. 2001. Molecular systematics of the Oncidiinae based on evidence from four DNA sequence regions: expanded circumscriptions of Cyrtochilum, Erycina, Otoglossum, and Trichocentrum and a new genus (Orchidaceae). Lindleyana 16: 113-139.

Zappi, D.C.; Lucas, E.; Stannard, B.L.; Luchadha, E.N.; Pirani, J.R.; Queiroz, L.P.; Atkins, S.; Hind, D.J.N.; Giulietti, A.M.; Harley, R.M. \& Carvalho, A.M. 2003. Lista das plantas vasculares de Catolés, Chapada Diamantina, Bahia, Brasil. Boletim de Botânica da Universidade de São Paulo 21: 345-398.

\begin{abstract}
Lista de Exsicatas
Amorim, A.M. 2999 (3), 6924 (26); Andrade-Lima 6136 (11); Azevedo, C. 165 (5), 173 (10), 156 (24), 24 (47); Bastos, C.A. 1, 2 , 7, 125, 139, 277 (1), 165 (3), 154 (5), 68, 109, 119, 158, 180, 276 (6), 191 (8), 130, 178, 182 (9), 221, 244 (10), 267 (11), 206,209 (12), 6, 115, 159 (14), 94 (16), 274 (18), 89, 252 (19), 176 (20), 187 (23), 186 (24), $162(25), 3,88,117,118,273(26), 121(27), 226$ (29), 160, 201 (31), 272 (33), 243, 262 (41), 128, 140, 166 (45), 83 (47), 79, 81, 250 (49), 9, 157, 279 (51), 96 (53), 175, 205, 245 (53); Bautista, H.P. 939 (14); Borba, E.L. 2068 (4), 2071 (17), 1949 (18), 2067 (19), 2073 (27), 2069 (33), 2070 (47); Cardoso, D. 540, 642 (30); Conceição, S.F. 301 (26), 28 (43); Correia, C. 126 (14), 102 (26), 214 (53); Costa, A.L. s.n. ALCB 7252 (44); Cruz, D.T. 7, 8, 13 (1), 1, 25 (14), 6 (26), 3 (27), 2, 4 (49); D'Arcy, W.G.D. 11942 (51); Davidse, G. 11928 (1); Duarte, A.P. 14102 (1), 9195 (19), 9220 (41); Esteves, G.L. 2524 (14); Ferreira, J.L. 47 (1); Forzza, R.C. 1376 (43); França, F. 5227 (14), 1309 (16), 5377 (19), 5661 (23), 3997, 5370 (25), 3439 (36), 4056 (46), 1361 (48), 5334 (49); Furlan, A. 293 (4), 276 (19), 295 (25), 294 (49); Ganev, W. 3003 (8), 133 (15), 1301 (24), 2940 (32), 688 (50); Grupo Pedra do Cavalo 809 (10), 516 (52); Guedes, M.L. 10757 (6), 12851 (26), 12940 (52); Harley, R.M. 3180, 19332, 22783 (1), 22800 (3), 19205 (14), 55067 (15), 19380, 22896 (35), 22750 (36), 22810,23016 (37), 3114, 19284, 22874 (38), 19238, 19239 (51); Hatschbach, G. 39646 (1), 39603, 42392 (6), 39658 (19), 39619 (25), 39706 (28), 42403 (36), 42358 (38), 39607 (49); Junqueira, M.E.R. 150 (19), 134 (25), 152 (26), 148, 149 (49), 199 (53); Jurandir s.n. HUEFS 63117 (15); Kundergraber, H. s.n. SP 333602 (20); Lemos, M.J.S. 174 (14); Martinelli, G. 5221 (39); Martinho, A. s.n. SP 274802, s. n. SP 274802 (15); Marx, R.B. s.n. HB 69226 (51); Melo, E. 5071 (22), 4962 (23), 3289 (25), 5535 (26), 4848 (29), 5537, 5609, 5777 (34), 5844 (40), 4749, 4990 (43), 5223 (45), 5046 (48), 3131 (49), 5156 (52); Miranda, A.M. 237 (1), 238 (14); Miranda, E.B. 587 (26); Monteiro, S.H. 60 (HUEFS) (33); Mori, S.A. 14508 (35), 14459 (36); Nascimento, J.G.A. 201 (19), 195 (25), 187 (28); Noblick, L.R. 3532 (17); Nonato, F.R. 953, 954 (12), 961 (26), 989 (36), 1014 (40), 962 (50); Oliveira, A. 70 (14); Paula-Souza, J. 4774 (1); Pereira, C. 91 (27); Pereira, E. 10075 (6); Pereira-Silva, G. 8461 (1), 8467 (51); Queiroz, L.P. 1288, 4279 (1), 1262,7708 (6), 7688 (8), 971 (10), 1261 (19), 12994 (21), 1287 (25), 4288 (32); Rapini, A. 941 (19), 947 (25), 943 (26), 951 (32); Ribeiro, P.L. 23 (1), 29 (2), 27, 94, 97, 98, 99, 176 (6), 45, 113 (7), 48 (8), 20 (30), 21 (38), 28 (42), 89 (51); Roque, N. 1228 (6), 2328 (14); Smidt, E.C. 662 (44), 360 (50); Souza, E.R. 167 (43); Stannard, B. 7308 (46); Steinmann, V. 2212 (25); Thomas, W.W. 12786, 12899, s.n. HUEFS 84794 (14), 12898 (28); van den Berg, C. 1626 (13), 1059 (21), 1662 (40), 1660 (51); Vicente, J. 5436 (25), 5397 (26).
\end{abstract}


